An unusually complete suite of eclogite types:

Eclogite xenoliths from the Zero kimberlite, South Africa

\author{
I. Petrography, mineral chemistry and oxygen isotopes \\ II. The source of the eclogites inferred from trace elements
}

\author{
Dissertation \\ Zur Erlangung des Doktorgrades \\ der Mathematisch-Naturwissenschaftlichen Fakultäten \\ der Georg-August-Universität zu Göttingen
}

vorgelegt von

Bettina Schmickler

aus Leverkusen

Göttingen 2002 


\section{ZUSAMMENFASSUNG}

In der vorliegenden Arbeit wurden die Eklogitxenolithe des Zero Kimberlites untersucht, die aufgrund ihrer Vielfalt an Paragenesen und ihres Alters eine aussergewöhnliche Xenolithsuite darstellen. Der Zerokimberlit intrudierte zusammen mit 11 weiteren nichtdiamantführenden Kimberliten vor 1.6 Milliarden Jahren am Westrand des Kaapvaal Kratons in der Kurumanprovinz (Südafrika), welche die älteste Kimberlitprovinz auf dem Kaapvaal Kraton ist. Gefördert wurden neben einem aussergewöhnlichen Disthen-Eklogit, bimineralische Eklogite sowie eher selten auftretende Orthopyroxene-führende Eklogite mit und ohne Sanidin. In allen Paragenesen tritt aus Klinopyroxen entmischter Granat auf. In den Orthopyroxenführenden Eklogiten tritt ebenfalls Orthopyroxen und, wenn vorhanden, auch Sanidin entmischt aus Klinopyroxen auf. Das ungewöhnliche Vorkommen von Quarz-, Klinopyroxen- und Kalifeldspateinschlüssen in ideomorphen Granatkernen der Eklogite erscheint zunächst als Hinweis auf einen krustalen Ursprung, welcher allerdings im Kontrast zu den $\delta^{18} \mathrm{O}$-Werten der Eklogite steht. Mit Werten zwischen 5.18 - 5.47 liegen diese im Bereich des unkontaminierten Mantels und lassen damit auf eine Mantelherkunft schließen. Ohne die Herkunft der Eklogite näher zu betrachten, beschäftigt sich der erste Teil der Arbeit mit dem P-T-t-Pfad, den die Eklogitsuite beschreibt. Mit Hilfe von Thermobarometrie und dem rekonstruierten Kaliumgehalt in Klinopyroxen der präentmischten Sanidin führenden Eklogite, ließen sich zwei verschiedene Stadien der Eklogite im Erdmantel zurückverfolgen. Während die letzte Reequilibrierungsphase, bevor die Eklogite vom Kimberlit eruptiert wurden, bei etwa $950^{\circ} \mathrm{C}$ und $3.5 \mathrm{GPa}(110 \mathrm{~km}$ Tiefe) stattfand, deutet der ehemalige, erhöhte Kaliumgehalt der Sanidin Eklogite, welcher als Hochdruckindikator gilt, darauf hin, daß die Xenolithe aus einem Druckbereich von mindestens 6 GPa (min. 180 $\mathrm{km}$ Tiefe) stammen.

Der 2. Teil der Arbeit beschäftigt sich mit der Genese der Zero Eklogitxenolithe. Generell wird die Herkunft von Eklogitxenolithen in der Literatur noch immer kontrovers diskutiert, die dabei entweder als Hochdruck- oder Niedrigdruckkumulate interpretiert werden. Untersuchungen der Spurenelemente an Mineralen aller Eklogitparagenesen ergaben, daß es sich bei den Zero-Eklogiten um fraktionierte Kumulate handelt. Die Eklogite zeigen generell sehr niedrige Spurenelementkonzentrationen, wobei die "Seltenen Erden" entweder sehr nahe am primitiven Mantel liegen, oder dem Mantel gegenüber sogar abgereichert sind. Eine Anreicherung an "Leichten Seltenen Erden", die in vielen Eklogiten zu beobachten ist, läßt sich auf eine Metasomatose zu einem späten Zeitpunkt zurückführen. Positive Eu-Anomalien die durch den Hinweis auf Plagioklas im Protolith als Indikatoren einer Niedrigdruckgenese gelten, treten lediglich im Disthen Eklogit und im bimineralischen Eklogit Z323 auf, nicht aber in den anderen Eklogiten. Demgegenüber liefern erhöhte $\mathrm{Cr}$ und Ni Gehalte in einigen Orthopyroxen-führenden Eklogiten, Hinweise auf primären Olivin oder Cr-Spinel im Protolith. Die geringen Spurenelementkonzentrationen, inklusive der niedrigen $\mathrm{Nb}, \mathrm{Ta}, \mathrm{Zr}$ und $\mathrm{Hf}$ Gehalte scheinen charakteristisch für die Eklogitsuite zu sein. Um der Frage nachzugehen, ob es sich bei den Eklogiten um Hoch oder Niedrigdruckkumulate handelt, wurden Haupt- und Spurenelementmodellierungen kombiniert, die zeigen, dass die Eklogite durch fraktionierte Kristallisation von einem pikritischen Magma gebildet wurden, dessen maximale Entstehungstiefe bei $1.8 \mathrm{GPa}$ lag. Magmen aus größeren Tiefen sind $\mathrm{MgO}$ reicher und damit komatiitisch und führen weder bei fraktionierter Kristallisation bei Hochdruck noch bei niedrigen Drücken zu Kumulaten eklogitischer Zusammensetzung. Die modellierten Kumulate, die mit der Chemie der ZeroEklogite die größte Übereinstimmung zeigten, wurden bei maximalen Tiefen von 1.0-1.5 GPa fraktioniert. Weiterhin zeigte die Modellierung, daß für eine eklogitische Zusammensetzung zumindest geringe Mengen an Plagioklas notwendig sind und Protolithe von Eklogiten deshalb nicht außerhalb des Plagioklasstabilitätsfeldes gebildet wurden und von daher nicht, wie oft in der Literatur behauptet aus großen Tiefen stammen können. Die Rekonstruktion des P-T-t-Pfades der Eklogite läßt insofern Rückschlüsse auf die Geologische Situation am Westrand des Kaapvaal Kratons zu, als daß der Grund für die Eklogitisierung, bzw. den Versatz der Zero Eklogite von mindestens $150 \mathrm{~km}$ in die Tiefe des Erdmantels, die Kollision des Kheis-belts mit dem Westrand des Kaapvaal Kratons im Verlauf der Kheis Orogenese (vor ca. 1.75 Milliarden Jahren) war. 


\section{AN UNUSUALLY COMPLETE SUITE OF ECLOGITE TYPES 3 ECLOGITE XENOLITHS FROM THE ZERO KIMBERLITE, SOUTH AFRICA}

I. Petrography, Mineral CHEMistry AND OXYGEN ISOTOPES

1. INTRODUCTION 3

1.1 LOCALITY AND SAMPLE DESCRIPTION

2. ANALYTICAL METHODS

2.1. ELECTRON MICROPROBE (EPMA)

2.2 OXYGEN ISOTOPE ANALYSES

$\begin{array}{lll}2.3 & \text { RAMAN SPECTROSCOPY } & 7\end{array}$

3. CONSTITUENTS AND TEXTURES OF THE ECLOGITES 8

4. RESULTS

4.1. CHEMICAL COMPOSITION AND CLASSIFICATION OF THE ECLOGITES

4.2 THERMOBAROMETRY 20

4.3 EVALUATION OF PREVIOUS P/T CONDITIONS

4.3 DETERMINATION OF THE GARNET INCLUSIONS USING RAMAN SPECTROSCOPY 22

4.5 OXYGEN ISOTOPIC COMPOSITIONS OF THE ZERO ECLOGITES

5. DISCUSSION

5.1 THE SOURCE FOR "MANTLE ECLOGITES" IS STILL ENIGMATIC

5.2. THE ORIGIN OF DIFFERENT ZERO ECLOGITE TYPES 26

5.3. THE MANTLE HISTORY OF THE ECLOGITES RECONSTRUCTED ON THE P-T-T-PATH OF THE SANIDINE ECLOGITES

6. REFERENCES

II. THE SOURCE OF THE ZERO ECLOGITE XENOLITHS 33

INFERRED FROM TRACE ELEMENTS

1. INTRODUCTION

$\begin{array}{lll}\text { 1.1 ZERO ECLOGITES } & 34\end{array}$

2.1 TRACE ELEMENT COMPOSITION OF THE ECLOGITES

$\begin{array}{lll}2.1 .1 & \text { Garnet } & 38\end{array}$

2.1.2 Clinopyroxene 40

2.1.3 Accessory phases: sanidine and orthopyroxene 40

3. DISCUSSION $\quad 40$

$\begin{array}{llr}3.1 & \text { PARTITION COEFFICIENTS } & 40\end{array}$

3.2 TRACE ELEMENT WHOLE ROCK COMPOSITION 41

3.2.1 Sanidine and orthopyroxene bearing eclogites 44

3.2.2 Bimineralic eclogites and the kyanite eclogite 43

3.3 PROCESSES AND PROTOLITHS FOR THE ECLOGITES INDICATED BY TRACE ELEMENT ABUNDANCES 46

3.4 THE ORIGIN OF ZERO ECLOGITES EVIDENCED BY TRACE ELEMENTS

3.5 MODELS FOR THE FORMATION OF THE ZERO ECLOGITES

3.6 GEODYNAMIC ASPECTS

$\begin{array}{lr}\text { 4. REFERENCES } & 58\end{array}$

5. ACKNOWLEDGMENTS 


\title{
An unusually complete suite of eclogite types \\ Eclogite xenoliths from the Zero kimberlite, South Africa
}

\section{Petrography, mineral chemistry and oxygen isotopes}

\begin{abstract}
This first investigation of eclogite xenoliths sampled by the Zero kimberlite show that the suite is exceptional concerning kimberlite age and diversity of eclogite types. The Zero kimberlite intruded as part of a sequence of nondiamond bearing kimberlites within the oldest kimberlite province on the Kaapvaal craton (1600 Ma; Northern Cape Province, South Africa) towards the western craton margin. Distinct eclogite parageneses, including bimineralic eclogites, usually rare orthopyroxene-bearing eclogites with and without sanidine in addition to one kyanite eclogite occur in the suite. Garnets exsolved from clinopyroxene host occur in all Zero eclogites, whereas in orthopyroxene bearing eclogites, orthopyroxene and, if present, sanidine are also exsolved from clinopyroxene. That most eclogites occur with quartz, rutile and rarely K-feldspar inclusions in garnets might be taken to imply a crustal precursor. However, this is in conflict with the analyzed oxygen isotopic composition of the eclogites, which yield $\delta^{18} \mathrm{O}$ values of 5.18-5.47, close to values for the uncontaminated Earth's mantle. Irrespective of the original source of the eclogite suite, a complex history within the mantle can already be inferred from the exsolved constituents of the sanidine eclogites. Thermobarometrical results indicate the last $\mathrm{P} / \mathrm{T}$ condition prior to the kimberlite eruption was at $900-950{ }^{\circ} \mathrm{C}$ at $3.5 \mathrm{GPa}$. The previous stage was deduced from the reconstructed $\mathrm{K}_{2} \mathrm{O}$-content of clinopyroxene host prior to the exsolution of sanidine. High $\mathrm{K}_{2} \mathrm{O}$ contents in clinopyroxene, which apparently resulted from the breakdown of dehydrating phlogopite are typical of high pressures and can be used as a crude barometer. The $\mathrm{K}_{2} \mathrm{O}$ content of $0.2 \mathrm{wt} \%$ calculated by phase map analysis requires pressure conditions of 6-8 GPa. Hence the eclogites were carried to $180-210 \mathrm{~km}$ depth prior to their exhumation.
\end{abstract}

\section{Introduction}

Eclogites form a minor but important proportion of xenoliths emplaced from mantle depths into cratons by kimberlites, allowing investigation of the chemical composition and geodynamic processes of the ancient and modern upper mantle. Numerous case studies, mostly on bimineralic eclogite xenoliths consisting of garnet and clinopyroxene from Roberts Victor and Bellsbank (R.S.A), Orapa (Botswana), Udachnaya (Russia) and Koidu, (Sierra Leone) led to several models for eclogite classification and origins (Beard et al., 1996); Barth et al., 2001; Hatton, 1978; Jagoutz et al., 1984; Jacob and Jagoutz, 1994; Jerde et al.; 1993; Snyder et al., 1997; Viljoen et al. 1996). However, eclogite genesis is still debated and opinions are divided between two extreme views that describe them as relics of subducted oceanic crust (e.g. Helmstaedt and Doig, 1975; Jagoutz et al., 1984; MacGregor and Manton, 1986; Jacob and Jagoutz, 1994; Jagoutz et al., 1984) or as cumulates from melts crystallized at high-pressure that had never been close to Earth surface (e.g. O'Hara and Yoder, 1967; Hatton, 1978; Smyth et al., 1989; Snyder et al., 1993). A textural approach interpreting eclogites as melts and 
cumulates combined both hypotheses by distinguishing Group I eclogites, which might have formed through partial melting of subducted crust from Group II eclogites, representing the reaction products of the volatile-enriched aureole between Group I eclogites and the surrounding peridotite (MacGregor and Carter, 1970; MacGregor and Manton, 1986). The majority of diamond occurrences in kimberlites and lamproites are linked to eclogitic environments though eclogites occur less abundant compared to peridotitic mantle fragments. This has led to the assumption eclogite is unlikely to represent more than a few percent of the upper mantle volume (Schulze, 1989). The fact that diamond inclusions particularly from ultra-deep origin (>300 km) are also eclogitic (Stachel et al., 2000) implies that eclogites may provide important evidence about composition and evolution even of lower parts of the Earth's upper mantle.

Though a subduction origin for eclogites xenoliths was previously proposed (Ringwood and Green, 1966; Green and Ringwood, 1967a; Green and Ringwood, 1967b) important results which were used to advocate the subduction hypothesis came from stable oxygen isotopic studies (e.g. Garlick et al., 1971; MacGregor and Manton, 1986). Since the fractionation of oxygen isotopes is a strong function of temperature whereas pressure effects are negligible, $\delta^{18} \mathrm{O}$ values deviating from the restricted value for unaltered mantle peridotite of 5.5 $\pm 0.4 \%$ (Mattey et al., 1994) was apparently produced by hydrothermal alteration at different temperatures. Hence an origin as subducted crust was suggested for those eclogites xenoliths which show variable $\delta^{18} \mathrm{O}$ values (Jagoutz et al., 1984; Jacob and Jagoutz, 1994; Barth et al., 2001; Jacob and Foley, 1999) comparable to the range of oxygen isotopes observed in seawater-altered oceanic crust (e.g. Alt et al., 1986) and ophiolites (e.g. McCulloch et al. 1981; Gregory and Taylor, 1986). Based on the range in oxygen isotopes a crustal precursor was proposed for the Roberts Victor eclogite suite, for which cumulate gabbros (group I eclogites), which experienced high-temperature alteration, have been distinguished from low temperature altered oceanic basalts (group II eclogites, MacGregor and Manton, 1986) that are found in the shallowest portions of the oceanic crust. Since free silica and K-feldspar would be stable in eclogites formed by high-pressure metamorphism of quartz-normative tholeiitic basalts, which can only be derived from depths less than $1 \mathrm{GPa}$ (Green and Ringwood, 1967a, 1967b) a further subducted origin was suggested for those eclogites with accessory coesite and sanidine (Schulze et al., 2000). The occurrence of latter constituents is not compatible with a formation by fractional crystallization, since both phases would be expected only in the most evolved magmas but not in eclogitic composition.

That eclogite xenoliths can be affected by partial melting during subduction processes was shown by trace element studies on bimineralic eclogites from Udachnaya (Siberia) (Jacob and Foley, 1999) and on bimineralic eclogites from Koidu (Sierra Leone). The latter samples were subdivided into low $\mathrm{MgO}$ rocks, which are explained as partially melted remnants of oceanic crust and high $\mathrm{MgO}$ eclogites representing metamorphosed olivine gabbros and troctolites from basal parts of oceanic crust (Barth et al., 2001). Recent results suggest that many eclogites are residues after partial melting of amphibolites produced during the formation of trondjemites and tonalites in Archean times. In this respect they are proposed as residues from Archean continental crust formation (Rapp and Watson, 1995; Jacob and Foley, 1999; Barth et al., 2001).

Since the majority of eclogitic xenoliths from kimberlites studied to date are bimineralic, (consisting of garnet and clinopyroxene only) their geochemical studies are restricted. Furthermore, conventional radiogenic isotope and whole rock trace element analysis are complicated by the contamination due to the kimberlite melt. This means that models for their origin are forced to remain speculative to some extent, particularly because P-T estimates are rarely possible. Fortunately the Zero eclogite suite bears mineral phases additional to clinopyroxene and garnet, such as kyanite, quartz and particular orthopyroxene and sanidine that allow constraints on the P-T history of the eclogites directly prior to entrainment by the kimberlite to be made. Furthermore, these mineral parageneses places this eclogite suite somewhere transitional between 
those for which a subduction origin is favoured and those eclogites that are explained as high pressure crystallized igneous cumulates (Neal et al., 1990). Since Zero eclogites xenoliths occur with textures which resulted from sub-solidus exsolution of garnet from clinopyroxene it seems that a smooth transition from garnet pyroxenite to eclogite might be possible. The difference is outlined through the occurrence of either Tschermak's component in pyroxenites or jadeite component in eclogites. However, similar exsolution textures argue that eclogites have formed at distinct P-T conditions and might indicate the formation by fractional crystallization.

Due to the rich mineral inventory and special features, the Zero eclogites may help to shed light on the genesis of eclogite xenoliths from kimberlites. This investigation together with a companion paper focuses on the complete eclogite suite from the Zero kimberlite. The objective of the present paper, part I, is to investigate and present results on petrography and phase petrologic characteristics, Raman spectroscopy, thermobarometry, based on major elements determined by electron probe (EPMA) and oxygen isotopic measurements. Part II examines trace element chemistry and integrates all data to a consistent petrologic model for the genesis of the Zero eclogites.

\subsection{Locality and sample description}

The Zero kimberlite is one of 12 kimberlites located in the Kuruman region of the Northern Cape Province (RSA), situated close to the W-margin of the Kaapvaal craton (Fig. 1).

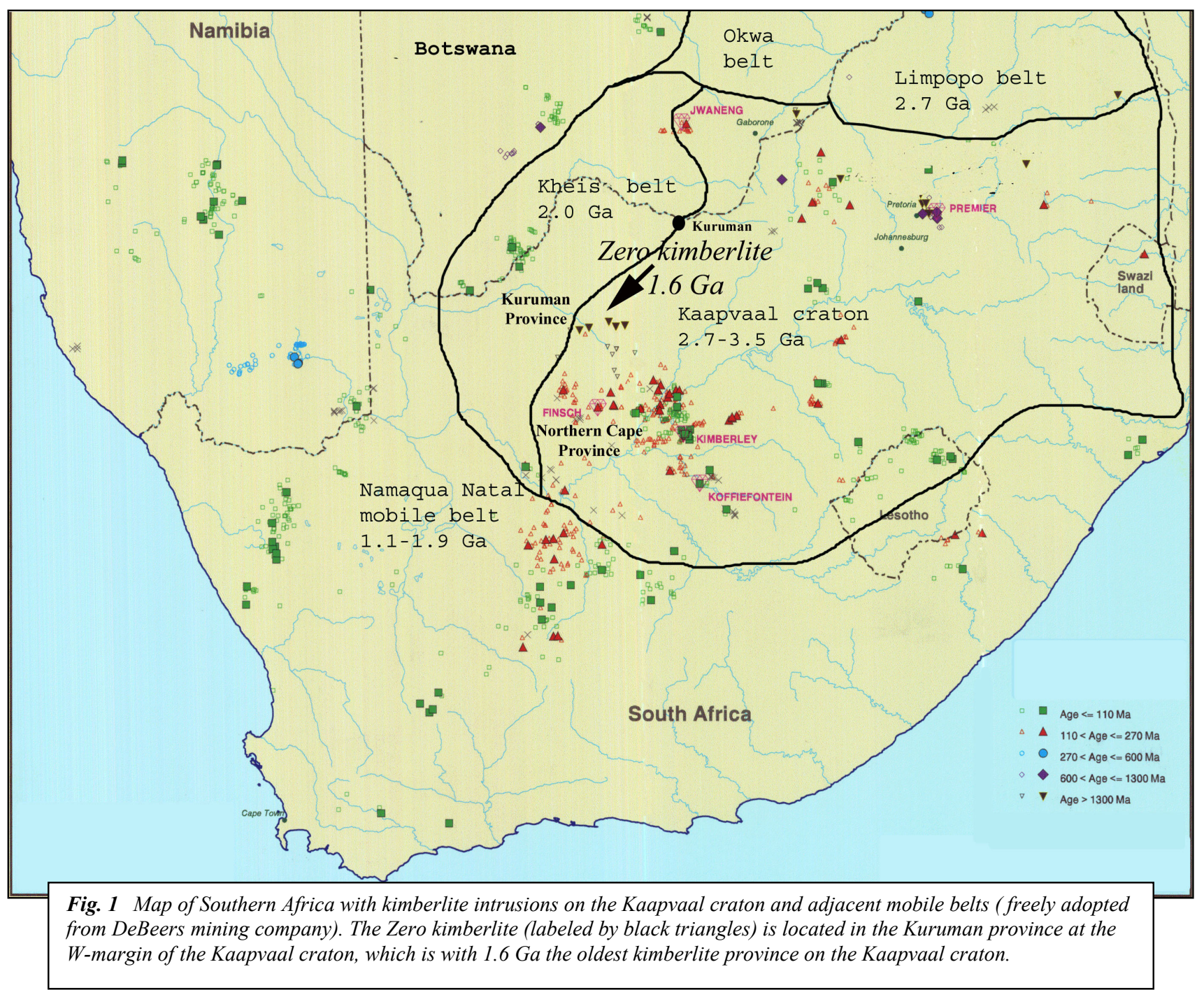


The non-diamondiferous Kuruman kimberlites (Riries, Bathlaros, Elston and Zero) yield ages of about 1.6 Ga (Shee et al., 1986) and hence represent the oldest kimberlite province on the Kaapvaal craton and second oldest worldwide (Kiviets et al., 1998). The variety of mantle xenoliths sampled by the Zero-kimberlite is remarkable since in addition to peridotites and pyroxenites, eclogites are unusually abundant. The peridotite xenoliths define a xenolith-geotherm (Smith et al., 1989) just above the diamond stability field and yield a geothermal gradient $>>40 \mathrm{~mW} / \mathrm{m}^{2}$ similar to higher gradients defined by off-craton kimberlites in the Gibeon and East Griqualand provinces (Mitchell, 1984; Boyd and Gurney, 1986). The tectonic setting of the Kuruman intrusives, which includes the Zero-pipe, is assumed to be typical for a cratonic margin, characterized by high heat flow and a thinner sub-cratonic lithosphere near the western edge of the craton $1600 \mathrm{Ma}$ ago (Shee et al., 1986).

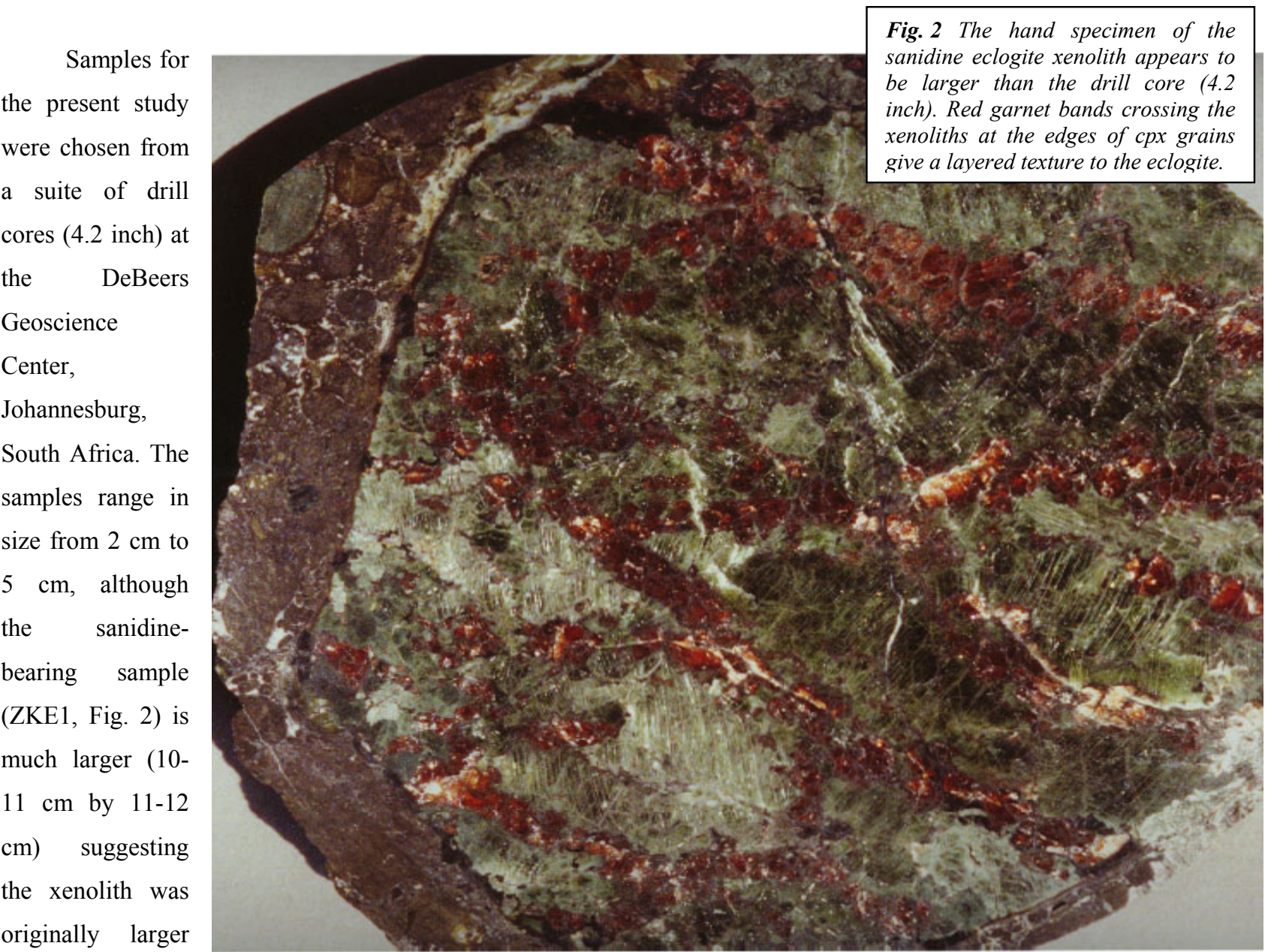

than the drill core. Different eclogite parageneses including sanidine- and orthopyroxene- bearing eclogites, bimineralic eclogites and the single kyanite eclogite occur, but all are dominated modally by clinopyroxene showing exsolved phases. Hence a smooth transition to pyroxenites, which are defined as products of igneous fractionation processes, might be possible. In hand specimen, garnets are dark reddish in color and clinopyroxenes pale green. Though sanidine and most orthopyroxene bearing samples are well preserved fine-grained oxides and sulphides occur in kelyphite rims around garnets, which occur in most Zero samples and are described from many xenolith localities (Fung and Haggerty, 1995). The latter alteration products are caused by decompression. Where carbonate filled cracks pervading the xenoliths occur a late infiltration of kimberlitic magma is apparent. However, reaction between the primary minerals and the host kimberlite is lacking, with the exception of sanidine. Sanidine, which occurs with abundant micro-inclusions, appears to be less resistant compared to the other minerals and provides a weak point for infiltration of the kimberlite magma. Thus, at sites where sanidine occurs connected with the kimberlite host, secondary phlogopite appears. A few bimineralic eclogites (Z298, Z185, Z257) show strong alteration along exsolution lamellae of clinopyroxene. However, retrograde reactions into plagioclase 
similar to those described from some Roberts Victor eclogites (Harte and Kirkley, 1997) can not be observed. Garnets are generally well preserved in all samples. For the purpose of investigating all parageneses for their chemical composition 5 bimineralic eclogites (Z184, Z239, Z257, Z298, Z323), 11 orthopyroxene bearing eclogites (Z175, Z185, Z188, Z330, Z263, Z217, Z332, Z341, Z291, Z202, Z469) plus 3 of them with sanidine (Z266, Z267, ZKE1) and 1 kyanite eclogite (Z356) were selected from a much larger collection. Thin sections were prepared partly at the DeBeers Geoscience Center and partly at the University of Göttingen.

\section{2. $\quad$ Analytical methods}

\subsection{Electron microprobe (EPMA)}

EPMA analysis of major-, minor-, and trace elements were performed on a JEOL 8900 at the Geochemisches Institut, Universität Göttingen equipped with 5 WDS spectrometers. Operating conditions for routine mineral analysis made on polished thin sections of the eclogite xenoliths were $15-20 \mathrm{kV}$ gun potential and acceleration voltage of 12-15 $\mu \mathrm{A}$ beam current with 15-30 seconds counting time on the peak of all measured elements. On average 10 analyses were performed on each mineral of all samples. For the purpose of determining zonation, traverses were made across individual grains for different constituents. Traces of $\mathrm{K}_{2} \mathrm{O}$ in clinopyroxene and $\mathrm{Na}_{2} \mathrm{O}$ in garnet were analyzed by increasing the probe current up to $60 \mu \mathrm{A}$ and increasing counting times to $120 \mathrm{~s}$, ensuring detection limits about $60 \mathrm{ppm}$ for $\mathrm{K}_{2} \mathrm{O}$ and $\mathrm{Na}_{2} \mathrm{O}$. The matrix correction phi-rho-zet was applied to process the raw counts. To reconstruct the whole rock composition, element mappings were performed of the complete xenoliths by recording $\mathrm{Al}, \mathrm{Mg}, \mathrm{Ca}, \mathrm{Fe}$ and $\mathrm{K}$ distributions within the eclogites and visualising the intensities of the characteristic x-rays of the scattering electron-beam. This technique offers a method of simultaneously determining the modal percentages of most constituent mineral phases of the eclogites. Element phase map analysis was used to assess the initial potassium content of the sanidine eclogites and to exclude secondary potassium bearing alteration products (e.g. phlogopite).

\subsection{Oxygen isotope analyses}

Clinopyroxenes and garnets were analyzed for oxygen isotopes using the laser fluorination technique at Royal Holloway University of London equipped with a $\mathrm{CO}_{2}$ Laser. Sample weights of handpicked and acid-leached mineral grains, free of inclusions and secondary alteration, ranged between 1 and $3 \mathrm{mg}$ for each analysis, which were all duplicated. The analyses were made by laser heating using a defocused Nd-Yag laser operating at $1.06 \mu \mathrm{m}$ in the presence of $\mathrm{ClF}_{3}$ at a pressure of 200 mbar. The oxygen isotope data were normalized to San Carlos olivine (4.88 \%o). Further details on the LF technique used are described by Mattey et al. (1994).

\subsection{Raman Spectroscopy}

Inclusions within the garnet grains were analyzed using Raman spectroscopy at the GeoForschungsZentrum Potsdam. The laboratory uses a Dilor XY Laser Raman Triple 800 mm spectrometer equipped with an Olympus optical microscope. The spectra are collected with a Peltier cooled CCD detector. At standard conditions the $514 \mathrm{~nm}$ line of a Coherent Ar Laser Model Innova 70-3 and a power of $150 \mathrm{~mW}$ of the argon laser are used for sample excitation. Raman spectroscopy has been used widely for identification of small fluid and solid inclusions and for the determination of the molecules 
structure (Rossmann, 1988). Hence polymorphic materials of the same chemical composition like coesite and quartz may be distinguished by their different spectra. The laser technique provides an efficient way to obtain the spectra of small specimens enclosed within transparent matrix.

\section{Constituents and textures of the eclogites}

1.) Orthopyroxene-bearing eclogites consisting of clinopyroxene, garnet and orthopyroxene with \pm rutile, quartz, phlogopite + ilmenite as accessories (samples: Z185, Z175, Z188, Z217, Z263, Z291, Z202, Z330, Z332, Z341, Z469).

1. a) Sanidine bearing subgroup: Similar to orthopyroxene-bearing eclogites, which occur with clinopyroxene, garnet, orthopyroxene and sanidine with rutile, quartz, phlogopite and ilmenite as accessories (samples: Z266, Z267, ZKE1). In all sanidine and orthopyroxene bearing samples, rutile inclusions occur in clinopyroxene.

2.) Bimineralic eclogites, consisting only of clinopyroxene and garnet (samples: Z185, Z239, Z257, Z298, Z323). Accessory minerals are lacking except in samples Z257 and Z298, which occur with rare rutiles in clinopyroxene. On the basis of chemical analyses Mg-rich eclogites (Z239 and Z298) may be distinguished from Ca-rich types (Z185 and Z323).

3.) A grospydite consists of clinopyroxene, garnet and kyanite with accessory Ba-feldspar (sample: Z356), which occurs without inclusions in clinopyroxene and garnet.

Different eclogite parageneses occur with distinct fabrics. Some eclogites show coarse lamellar textures (Fig. 3 (top) Z266, Z267, ZKE1, Z291, Z202, Z332, Z257, Z298, Z323) in contrast to those which occur with fine to medium granular textures (Fig. 3 (bottom) Z239, Z330) with straight edges and $120^{\circ}$ junctions (Harte and Gurney, 1975). The crystal size of clinopyroxene varies from sample to sample, but can be as large as $3 \mathrm{~cm}$ (Z341), which in this case produces the impression of a typical pyroxenite. Large clinopyroxene crystals showing exsolution lamellae dominate the eclogites, and are separated by chains of garnet giving them a necklace structure. Fine granular parts within the eclogites are made up of sub-spherical garnet and anhedral clinopyroxene with scattered exsolution lamellae. Nevertheless all eclogite parageneses show coarse, intermediate and fine garnet lamellae in clinopyroxene. In some samples, both lamellar and granular parts can be distinguished. Whether the exsolution occurs lamellar or granular is dependent on the initial grain size and differences in chemistry and modality of clinopyroxene (Fung and Haggerty, 1995). Similar exsolution intergrowths, which occur as common feature of all Zero eclogites, are due to their exsolution from clinopyroxene at low temperatures (or at high pressures), which is a common phenomenon in ultra-high and high-pressure rocks.

\section{Opx and sanidine bearing eclogites}

In contrast to different eclogite suites of kimberlites from the Kaapvaal- (Roberts Victor, Koidu) and Siberia cratons (Udachnaya, Mir) in which mostly bimineralic eclogites occur, it appears that orthopyroxene-bearing specimens are the dominant eclogite type in the Zero suite. The orthopyroxene bearing eclogites (including Z185, Z175, Z188, Z217, Z263, Z291, Z202, Z330, Z332, Z341 and Z469) consist mainly of granular clinopyroxene, garnet and orthopyroxene. Except samples Z330 and Z469, the eclogites occur with garnet and orthopyroxene exsolved from clinopyroxene. The coarse granular specimen Z469 and the more equi-granular sample Z330 show typical cumulate textures (Fig. 3 bottom) in contrast to samples Z291 and Z341, which have layered textures. With the exception of granular eclogites, garnets and orthopyroxene of the remaining samples occur interstitially arranged and appear in exsolution lamellae of variable thickness along thin bands. Both interstitial and exsolved orthopyroxene at clinopyroxene grain boundaries show continuous extinction under crossed polars, and are texturally similar to eclogites of Group I (Harte and Gurney, 1975). 
Accessory quartz, rutile and very rarely also K-feldspar inclusions less than $5 \mu \mathrm{m}$ in size occur in garnets of samples Z175, Z185, Z291, Z330 and Z332, whereas rutiles occur in clinopyroxene of all samples. In contrast, samples Z263, Z341 and Z469 occur without any inclusions in garnet. Phlogopite and ilmenite are secondary phases, which occur generally as alteration products either along exsolution lamellae in clinopyroxene or at xenolith margins. Apparently, due to the distinct garnet composition (and slightly higher $\mathrm{Cr}_{2} \mathrm{O}_{3}$ ) sample $\mathrm{Z} 217$ occurs in dark red color, and contains oriented ilmenite needles instead of rutile, which also occur in clinopyroxene. In the remaining samples, secondary ilmenite and phlogopite are observed mainly at rims of exsolution lamellae or xenolith margins.

The sanidine eclogites Z266, Z267 are small xenoliths but the bigger drilled sample ZKE1 (Fig. 2) has been split into several hand specimen and thin sections. ZKE1 show coarse granular and layered texture similar to some orthopyroxene bearing samples. Since clinopyroxene occurs in the latter sample in sizes up to $3.5 \mathrm{~cm}$ in longest dimension produces the impression of a pyroxenite. Garnet, orthopyroxene and sanidine occur along exsolution lamellae and in granular form at clinopyroxene grain boundaries (Fig. 4), separating the clinopyroxene grains from each other. Similar to orthopyroxene bearing eclogites without sanidine, garnet occurs generally in intergrowth with orthopyroxene. The fact that orthopyroxene and sanidine, which occur together with or occasionally enclosed in garnets along exsolution lamellae extinguish at the same angle, evidences that both exsolved from clinopyroxene. In opx bearing eclogites garnet appears to replace orthopyroxene since a.) exsolved garnet and orthopyroxene always occur together and show interlocked grain boundaries and b.) garnet is occasionally enclosed in orthopyroxene grains, but the opposite does not occur. Nevertheless, the sharp grain boundaries argue for the coupled exsolution of orthopyroxene and garnet from clinopyroxene caused by changed P/T conditions. Orthopyroxene apparently exsolved faster from clinopyroxene than garnet, which might be a result of differences in diffusion rates between $\mathrm{Fe}^{2+}$ and $\mathrm{Al}^{3+}$ depending on cation sizes (Sautter and Harte, 1988). However initial
Fig. 3 Photomicrographs of thin sections between crossed polars show two orthopyroxene bearing eclogites with layered (top, Z291) and cumulate textures (bottom, Z330). Top: Layered textures are provoked by exsolution lamellae of similar to Z330, which occur rather rarely, apparently, the exsolution took place at the grain boundaries due to initial smaller grain sizes.
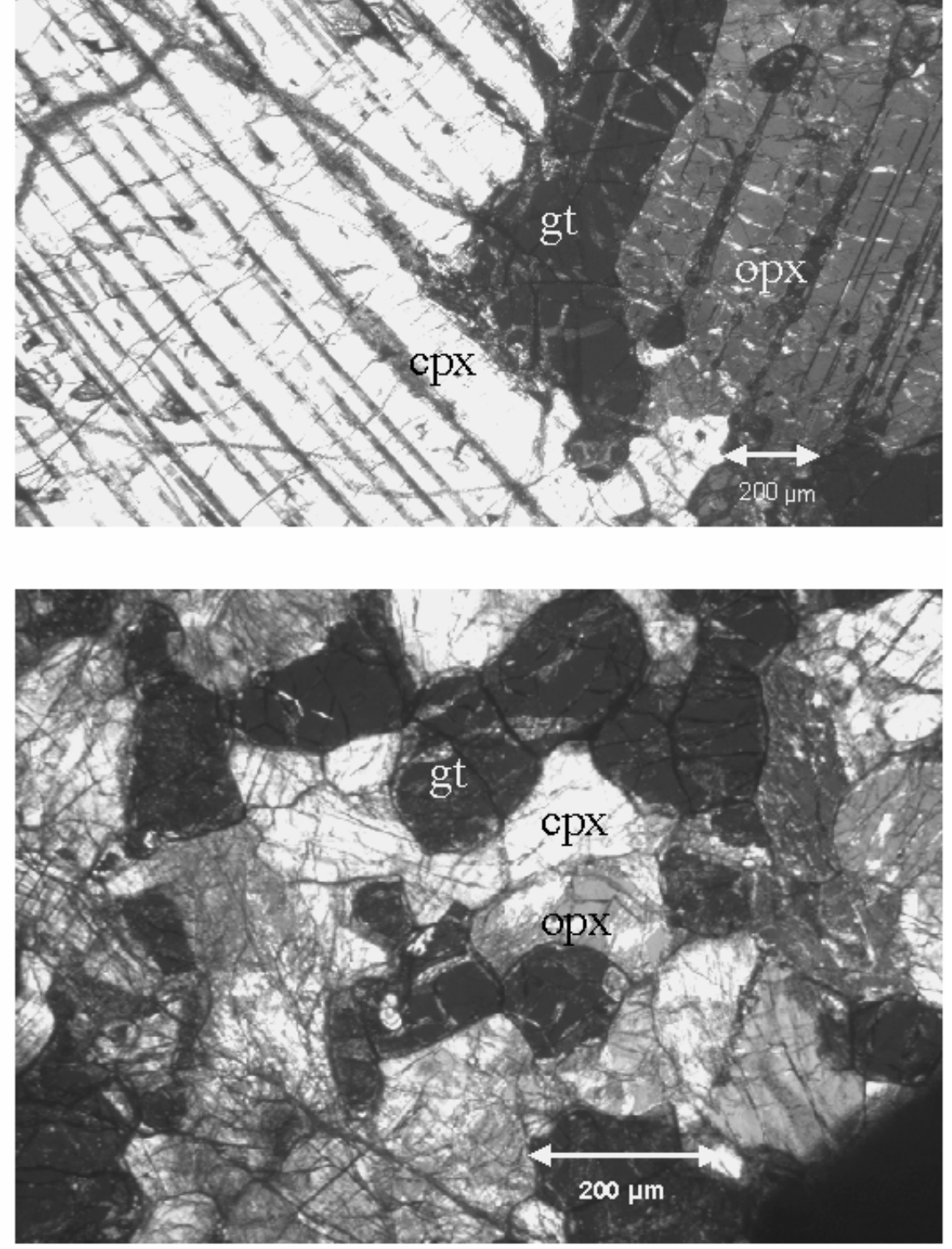
exsolution of orthopyroxene and garnet from clinopyroxene, which is a common feature in garnet pyroxenites, is due to the temperature and pressure dependent solubility of $\mathrm{Al}_{2} \mathrm{O}_{3}$ ( $\mathrm{Ca}$ Tschermak's) and $\mathrm{MgSiO}_{3}$ (enstatite) components within clinopyroxene (Herzberg, 1995). The MgO solubility in clinopyroxene decreases with decreasing temperature, whereas the $\mathrm{Al}_{2} \mathrm{O}_{3}$ solubility in clinopyroxene decreases with decreasing temperature and increasing pressure. Therefore the exsolutions from clinopyroxene may have formed during a period of decreasing temperature or increasing pressure or both. Solid-state diffusion is the driving force for the exsolution reaction, and is sensitive to prevailing temperature and pressure conditions (Sautter and Harte, 1988). The abundant occurrence of thin lamellae in one direction and coarser ones in different directions is apparently caused by the anisotropy properties of crystals in respect to diffusion.

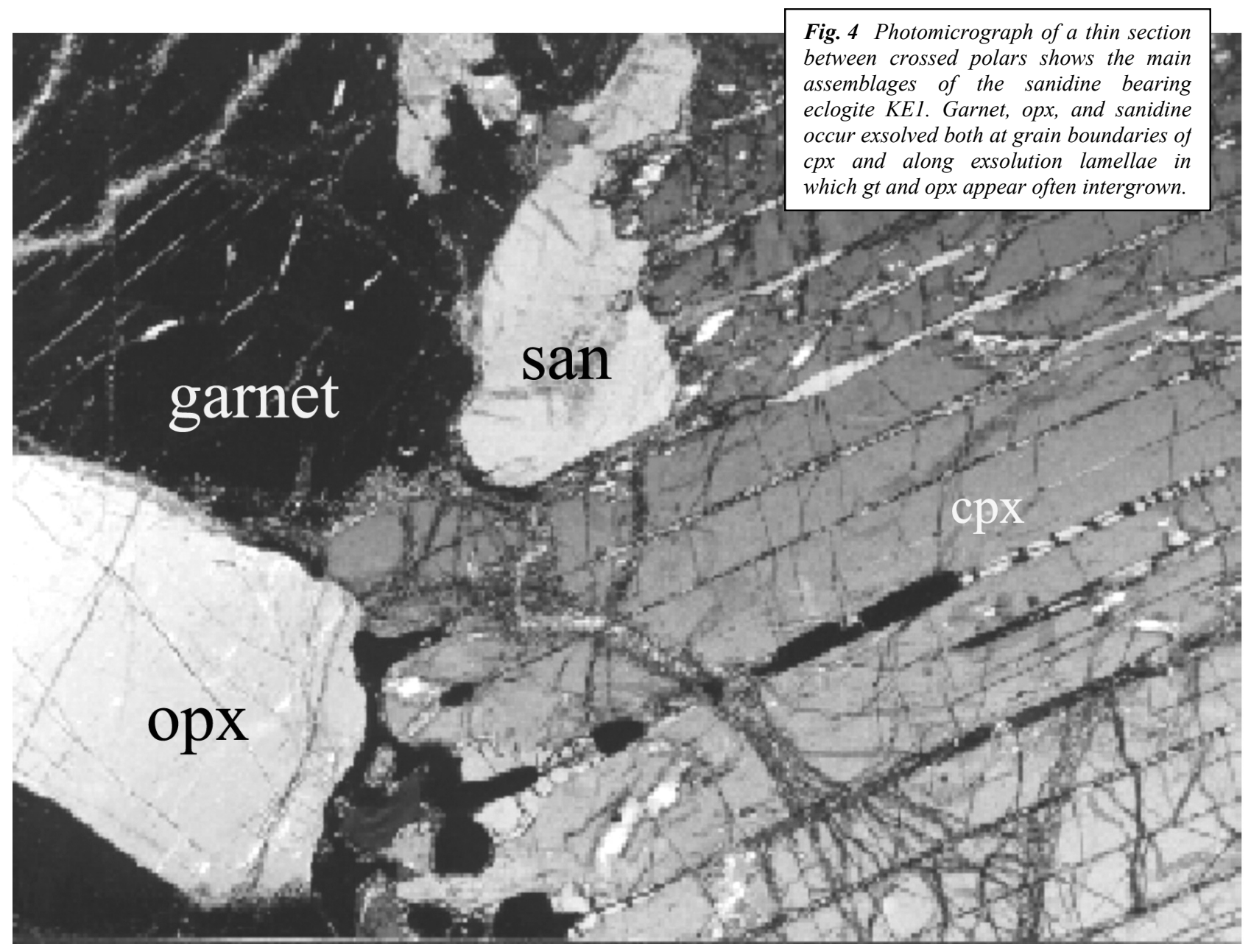

Clinopyroxene surrounding garnet bands, which traverses the xenolith gives the rock a layered texture. In contrast to partly elongated garnets within exsolution lamellae, garnets within the domains (Fig. 5) are euhedral. As in some orthopyroxene bearing eclogites the euhedral garnets contain abundant inclusions of quartz and rutiles, which are often intergrown, and less abundant feldspar and diopside inclusions occur. The latter inclusions have sizes between 5 to $10 \mu \mathrm{m}$ and occur significantly in cores but not in rims of the grains (Fig. 6a). The quartz inclusions occur with euhedral alpha quartz crystal shapes (Fig. 6b) in contrast to coesite occurrences described from Roberts Victor coesite eclogites (Mosenfelder, 1997). Most inclusions are surrounded by tiny dots less than $1 \mu \mathrm{m}$ in size, which are too small to be characterized by Raman spectroscopy, but might represent the residues of decrepitated fluid inclusions. Variations in the chemical composition between garnet cores, with inclusion and inclusion-free outer parts and between exsolved garnet from lamellae and granular garnets were not detected. 


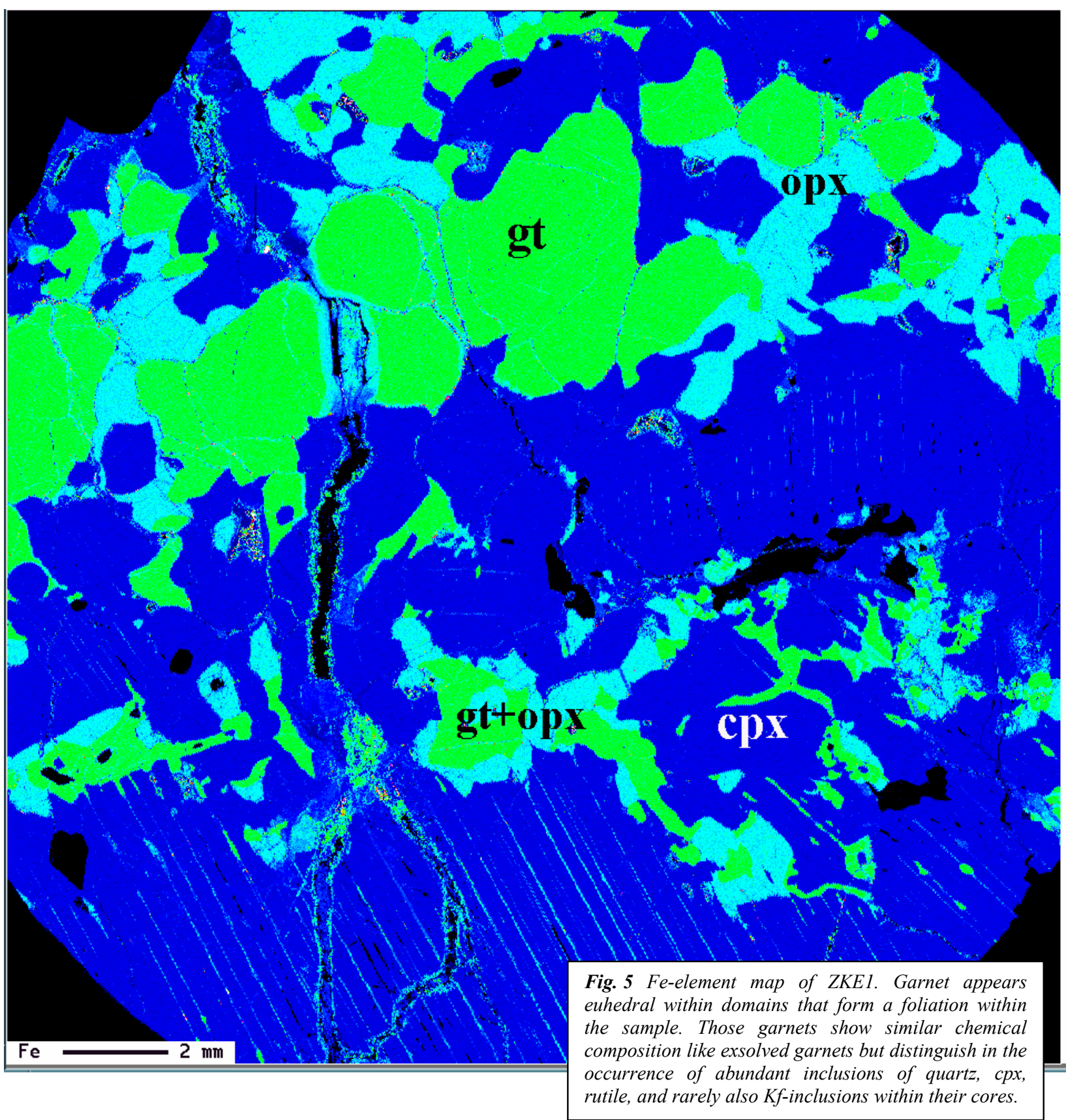

Similar to the sanidine free parageneses secondary phlogopite occurs connected with orthopyroxene or sanidine along exsolution lamellae or at xenolith rims. That sanidine and phlogopite might have formed through a K-Si-Mg-rich fluid or melt might be implied since both phases show accurate orientation of their grain boundaries. However, the similar crystal orientation of granular and lamellar sanidine proves that sanidine in fact exsolved from clinopyroxene, whereas phlogopite was formed later. According to thermodynamic calculations (Thermocalc) the coexistence of sanidine and phlogopite is likely under prevailing conditions $\left(900-950^{\circ} \mathrm{C}\right.$ at $\left.3.5 \mathrm{GPa}\right)$. Since phlogopite is not generally associated with the kimberlite, but occurs exclusively in exsolution lamellae where fluids found a path for percolation, argues for its formation by a metasomatic event prior to inclusion in kimberlite. A conceivable process producing secondary phlogopite might be a metasomatic reaction of sanidine in the presence of $\mathrm{H}_{2} \mathrm{O}$ or a water-rich melt or orthopyroxene with an alkaline fluid or melt. The same applies to ilmenite and sulphides, which may also be considered as late stage alteration products, either produced through a fluid or associated with the kimberlite melt. 


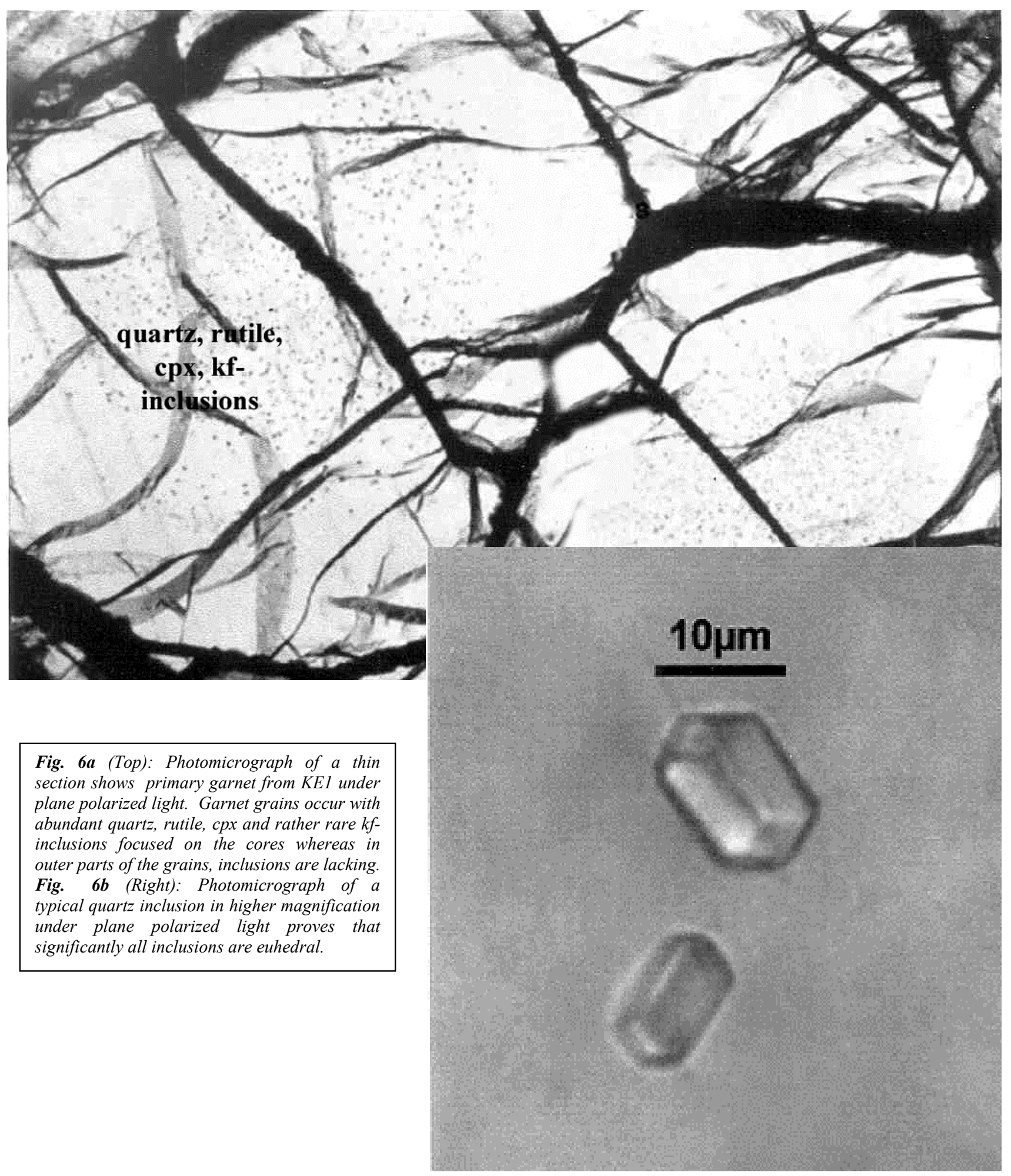

\section{Bimineralic eclogites}

Bimineralic eclogites consist of clinopyroxene and garnet only and except samples Z298 and Z257, which occur with small amounts of rutiles in clinopyroxene, accessory phases are lacking. Bimineralic eclogites occur with lamellar (Z185, Z257, Z323) and granular textures (Z298, Z239) (Harte and Gurney, 1975). In lamellar eclogites clinopyroxene crystals are generally larger than garnets, which occur in exsolution lamellae within clinopyroxene and in thin bands of interstitial grains. Sample Z323 consists of clinopyroxene mega-crysts with dense exsolution lamellae of garnet and small interstitial garnets (Fig. 7a). Sample Z185 contains anhedral, strongly exsolved clinopyroxene crystals separated by garnets, which form a 
prominent layering within the xenolith. In contrast, the granular sample Z298 shows anhedral, strongly exsolved clinopyroxene and large garnets from 4 to $9 \mathrm{~mm}$ in size. Sample Z239 exhibits a fine granular texture with clinopyroxene and garnet grains of similar sizes.

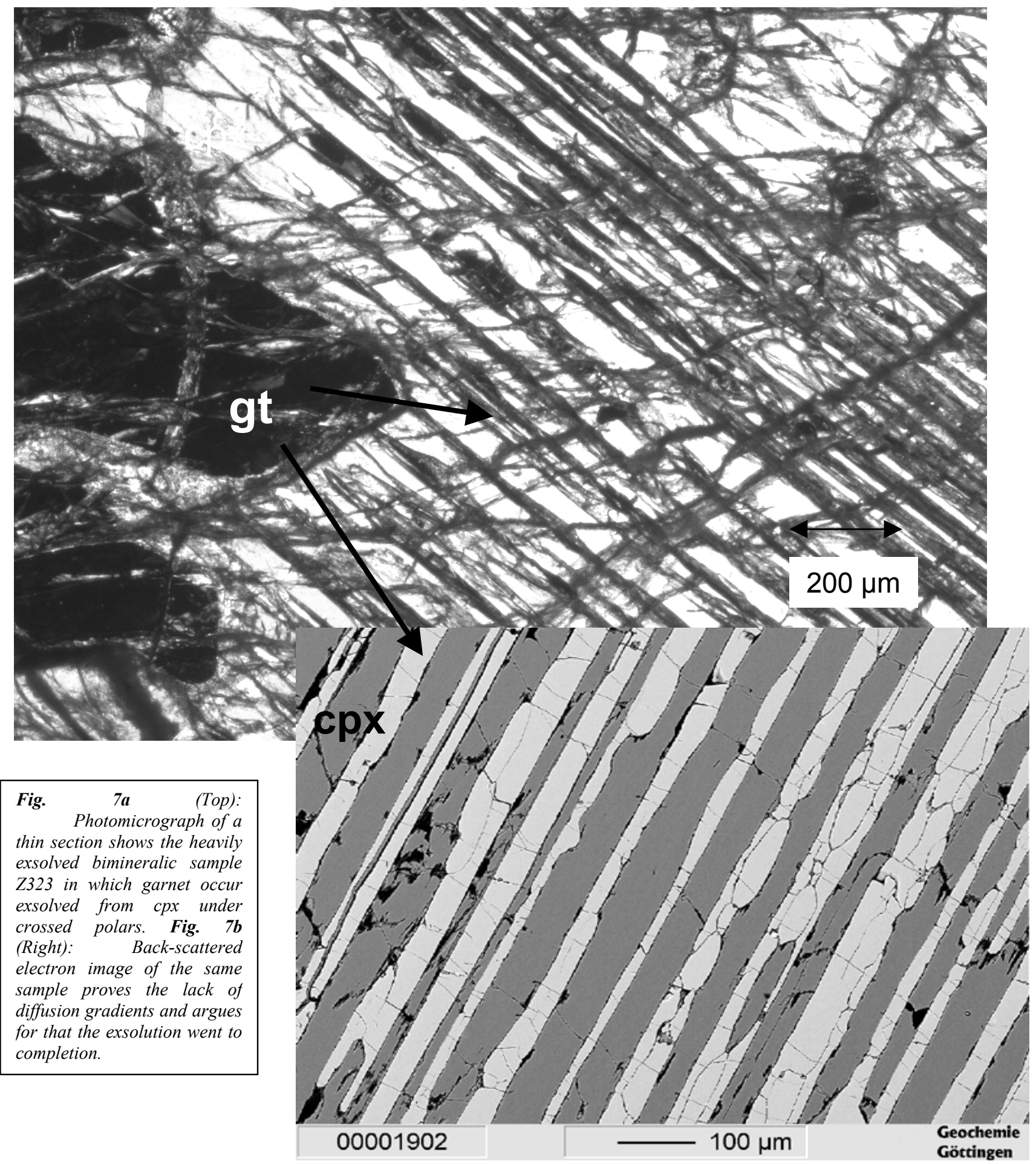




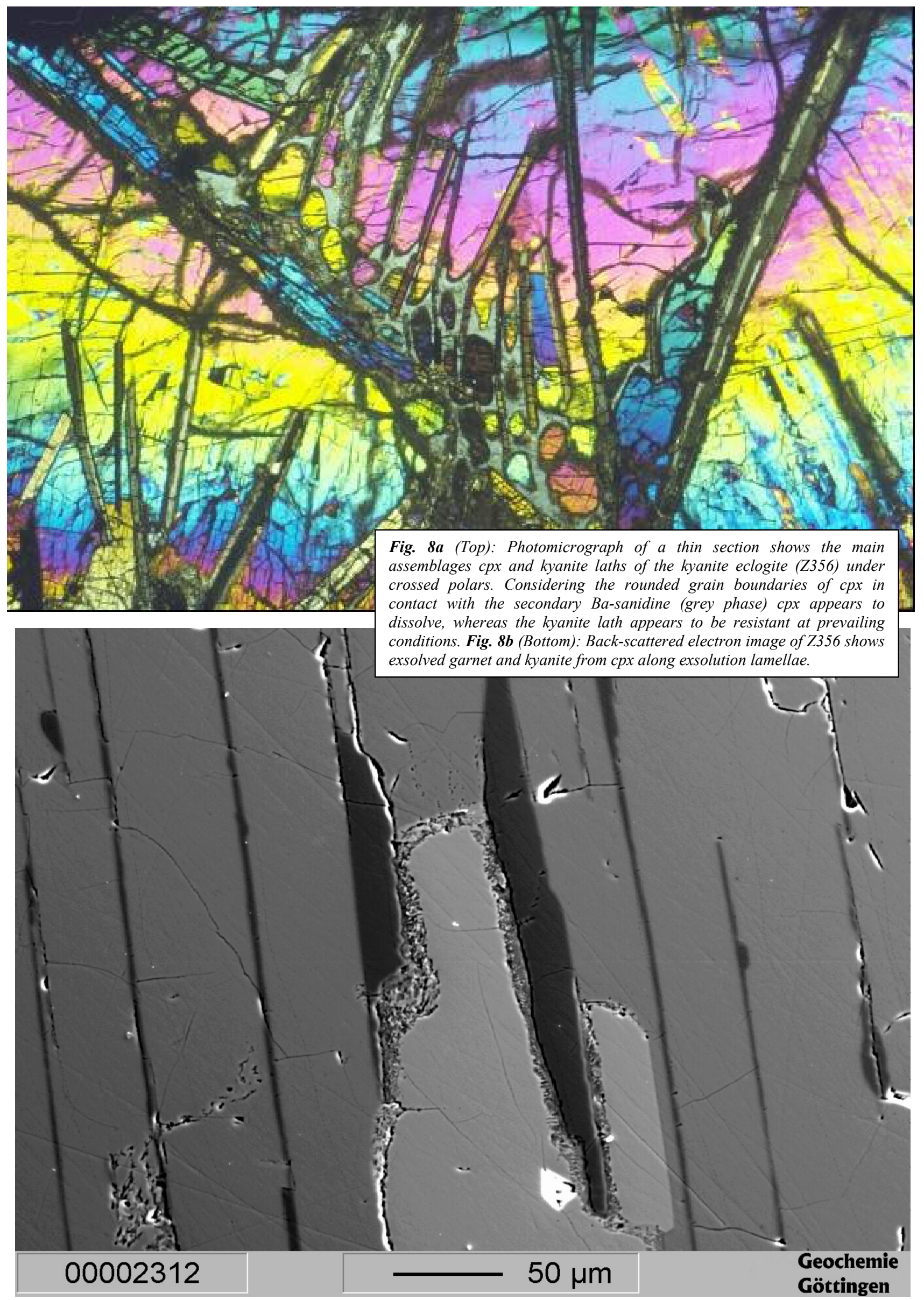




\section{Kyanite grospydite}

The only kyanite eclogite of the suite (Z356, Fig. 8a, b) is composed of omphacite, garnet and kyanite. Kyanite occurs both as lath-shaped single crystals and along exsolution lamellae in clinopyroxene (Fig. 8b). The eclogite is termed a grospydite (Bobrievich et al., 1960) since the coexisting garnet contains grossular component $>50 \mathrm{wt} \%$ (Table 1). Granular kyanite crystals occur as large elongated subhedral needles crosscutting garnet and clinopyroxene. The kyanite, which exsolved from clinopyroxene, occurs within regularly spaced and oriented lamellae. Garnet, which is less abundant (ca. $20 \%$ modal) occurs as small rods along exsolution lamellae exsolved from clinopyroxene. Sanidine occurs only as an accessory phase surrounding clinopyroxene and kyanite assemblages, at the grain boundaries of both phases (Fig. 8a). Kyanite laths remain unchanged in contact with the sanidine, whereas clinopyroxene, which occurs in rounded crystals, exhibits a slight brownish reaction rim. Nevertheless, it appears that clinopyroxene is no longer stable during the prevailing conditions. The reaction producing the kyanite laths involves the breakdown of plagioclase and Tschermak's rich clinopyroxene as initial composition, with prograde metamorphism.

$$
\begin{gathered}
\text { Ca-Tschermak }+ \text { albite }+ \text { anorthite } \rightarrow \text { omphacite }+ \text { grossular }+ \text { kyanite } \\
2 \mathrm{CaAl}^{\mathrm{VI}} \mathrm{Al}^{\mathrm{IV}} \mathrm{SiO}_{6}+\mathrm{NaAlSi}_{3} \mathrm{O}_{8}+\mathrm{CaAl}_{2} \mathrm{Si}_{2} \mathrm{O}_{8} \rightarrow \mathrm{NaAlSi}_{2} \mathrm{O}_{6}+\mathrm{Ca}_{3} \mathrm{Al}_{2} \mathrm{Si}_{3} \mathrm{O}_{12}+2 \mathrm{Al}_{2} \mathrm{SiO}_{5}
\end{gathered}
$$

\section{4. $\quad$ Results}

\subsection{Chemical composition and classification of the eclogites}

Average major and minor element compositions of garnet, clinopyroxene, orthopyroxene and sanidine from Zero eclogites are given in $\mathrm{wt}_{\mathrm{t}} \%$ oxides in Tables 1-3. Except the grospydite Z356, which has grossular rich garnets, the remaining Zero eclogites consist of pyrope rich garnets and omphacitic clinopyroxene with various jadeite contents. The orthopyroxene bearing eclogites show varying pyrope and grossular solid solutions with compositions $\operatorname{Py}_{72-50} \mathrm{Al}_{43-19} \mathrm{Gr}_{12-07}$. Associated omphacites, which occur as intergrowths with $\mathrm{Al}$ - and $\mathrm{Ca}-$ poor orthopyroxene $\left(\mathrm{Al}_{2} \mathrm{O}_{3}=0.8 \mathrm{wt} \% ; \mathrm{CaO}=0.4 \mathrm{wt}\right.$ \%), show deviating $\mathrm{MgO}$ and jadeite contents in the range $\mathrm{Wo}_{41-37} \mathrm{Hy}_{50-44} \mathrm{Jd}_{17-09}$. Similar to the latter samples the three orthopyroxene-bearing xenoliths with added sanidine occur with the average garnet composition of $\mathrm{Py}_{60} \mathrm{Al}_{32} \mathrm{Gr}_{08}$, and $12 \mathrm{w} \%$ jadeite content in omphacite. In contrast, garnet compositions of the bimineralic eclogites vary from $\mathrm{Py}_{70} \mathrm{Al}_{21} \mathrm{Gr}_{09}$ to $\mathrm{Py}_{46} \mathrm{Al}_{24} \mathrm{Gr}_{30}$ with $\mathrm{Mg} \#$ from 66 to 77. The garnet of the kyanite eclogite, which occurs exclusively in exsolution lamellae of clinopyroxene shows the average composition of $\mathrm{Gr}_{52} \mathrm{Al}_{13} \mathrm{Py}_{36}$. According to the classification of Bobrievich (Bobrievich et al., 1960) the latter sample is thus to be considered a grospydite $(\mathrm{Gr}>50)$. Compared to remaining Zero eclogites the omphacite from the grospydite shows with $24 \mathrm{wt} \%$ the highest jadeite content. Garnets of all paragenesis varies in $\mathrm{Ca} /(\mathrm{Ca}+\mathrm{Mg})$ from 0,19 to 0,61 which is accompanied with an obvious increase in $\mathrm{Ca} /(\mathrm{Ca}+\mathrm{Mg})$ of clinopyroxene, which is in turn associated with an increase in jadeite component. The highest jadeite contents occur in the bimineralic eclogites and in the kyanite eclogite, which show high $\mathrm{Mg} \#(86-95)$ and vary from 14 to 20 mole\% jadeite. 


\begin{tabular}{|c|c|c|c|c|c|c|c|c|c|c|c|c|c|c|c|c|c|c|c|c|}
\hline garnet & $\begin{array}{c}\text { Z184 } \\
\text { bi }\end{array}$ & $\begin{array}{c}\text { Z323 } \\
\text { bi }\end{array}$ & $\begin{array}{c}\text { Z257 } \\
\text { bi }\end{array}$ & $\begin{array}{c}\text { Z298 } \\
\text { bi }\end{array}$ & $\begin{array}{c}\text { Z239 } \\
\text { bi }\end{array}$ & $\begin{array}{l}\text { Z263 } \\
\text { opx }\end{array}$ & $\begin{array}{c}\text { Z217 } \\
\text { opx }\end{array}$ & $\begin{array}{c}\text { Z341 } \\
\text { opx }\end{array}$ & $\begin{array}{c}\text { Z469 } \\
\text { opx }\end{array}$ & $\begin{array}{c}\text { Z188 } \\
\text { opx }\end{array}$ & $\begin{array}{c}\text { Z185 } \\
\text { opx }\end{array}$ & $\begin{array}{c}\text { Z175 } \\
\text { opx }\end{array}$ & $\begin{array}{c}\text { Z332 } \\
\text { opx }\end{array}$ & $\begin{array}{c}\text { Z330 } \\
\text { opx }\end{array}$ & $\begin{array}{c}\text { Z291 } \\
\text { opx }\end{array}$ & $\begin{array}{c}\text { Z202 } \\
\text { opx }\end{array}$ & $\begin{array}{c}\text { Z266 } \\
\text { san }\end{array}$ & $\begin{array}{c}\text { Z267 } \\
\text { san }\end{array}$ & $\begin{array}{c}\text { ZKE1 } \\
\text { san }\end{array}$ & $\begin{array}{c}\text { Z356 } \\
\text { ky }\end{array}$ \\
\hline $\mathrm{SiO}_{2}$ & 41.21 & 40.90 & 41.08 & 42.45 & 42.03 & 41.55 & 40.57 & 40.56 & 41.59 & 41.09 & 41.91 & 41.36 & 40.05 & 41.26 & 41.89 & 40.93 & 41.18 & 40.40 & 40.87 & 40.94 \\
\hline $\mathrm{TiO}_{2}$ & 0.03 & 0.04 & 0.12 & 0.05 & 0.05 & 0.03 & 0.12 & 0.08 & 0.12 & 0.06 & 0.01 & 0.06 & 0.09 & 0.08 & 0.06 & 0.06 & 0.06 & 0.09 & 0.07 & 0.01 \\
\hline $\mathrm{Al}_{2} \mathrm{O}_{3}$ & 22.60 & 22.75 & 22.91 & 23.57 & 22.99 & 23.12 & 21.49 & 22.67 & 22.96 & 22.61 & 23.20 & 22.62 & 22.00 & 21.97 & 22.83 & 23.58 & 22.63 & 22.64 & 22.89 & 22.72 \\
\hline $\mathrm{Cr}_{2} \mathrm{O}_{3}$ & 0.10 & 0.22 & 0.28 & 0.11 & 0.41 & 0.15 & 0.73 & 0.11 & 0.24 & 0.16 & 0.11 & 0.29 & 0.10 & 1.21 & 0.42 & 0.25 & 0.21 & 0.28 & 0.23 & 0.09 \\
\hline $\mathrm{FeO}$ & 12.67 & 12.33 & 14.41 & 11.13 & 10.50 & 14.12 & 17.52 & 17.81 & 12.48 & 18.10 & 9.48 & 14.46 & 20.75 & 14.98 & 13.10 & 15.00 & 15.42 & 17.09 & 16.42 & 6.36 \\
\hline $\mathrm{MnO}$ & 0.42 & 0.34 & 0.39 & 0.37 & 0.30 & 0.52 & 0.45 & 0.68 & 0.31 & 0.62 & 0.30 & 0.43 & 0.58 & 0.36 & 0.31 & 0.43 & 0.46 & 0.54 & 0.49 & 0.31 \\
\hline $\mathrm{MgO}$ & 13.82 & 12.17 & 16.37 & 19.26 & 19.45 & 16.02 & 14.36 & 14.51 & 18.20 & 14.65 & 16.22 & 16.82 & 12.58 & 16.38 & 17.77 & 16.27 & 16.38 & 14.82 & 15.34 & 9.95 \\
\hline $\mathrm{CaO}$ & 9.47 & 11.80 & 5.09 & 4.68 & 4.70 & 5.81 & 5.28 & 4.63 & 4.72 & 4.36 & 9.62 & 4.47 & 4.69 & 4.63 & 4.32 & 4.33 & 4.43 & 4.56 & 4.55 & 19.61 \\
\hline $\mathrm{Na}_{2} \mathrm{O}$ & 0.01 & 0.01 & 0.03 & 0.02 & 0.02 & 0.02 & 0.03 & 0.01 & 0.03 & 0.02 & 0.01 & 0.02 & 0.01 & 0.03 & 0.02 & 0.04 & 0.01 & 0.01 & 0.02 & 0.00 \\
\hline total & 100.4 & 100.6 & 100.7 & 101.6 & 100.5 & 101.3 & 100.6 & 101.1 & 100.7 & 101.7 & 100.9 & 100.6 & 100.9 & 100.9 & 100.8 & 100.9 & 100.8 & 100.5 & 100.9 & 100.0 \\
\hline $\mathrm{Si}$ & 3.00 & 2.99 & 2.97 & 2.99 & 2.99 & 2.99 & 2.98 & 2.96 & 2.97 & 2.99 & 2.99 & 2.99 & 2.97 & 2.99 & 3.00 & 2.95 & 2.98 & 2.96 & 2.97 & 3.00 \\
\hline $\mathrm{Ti}$ & 0.00 & 0.00 & 0.01 & 0.00 & 0.00 & 0.00 & 0.01 & 0.00 & 0.01 & 0.00 & 0.00 & 0.00 & 0.00 & 0.00 & 0.00 & 0.00 & 0.00 & 0.00 & 0.00 & 0.00 \\
\hline $\mathrm{Al}$ & 1.94 & 1.96 & 1.95 & 1.95 & 1.93 & 1.96 & 1.86 & 1.95 & 1.93 & 1.94 & 1.95 & 1.93 & 1.92 & 1.88 & 1.93 & 2.01 & 1.93 & 1.96 & 1.96 & 1.96 \\
\hline $\mathrm{Cr}$ & 0.01 & 0.01 & 0.02 & 0.01 & 0.02 & 0.01 & 0.04 & 0.01 & 0.01 & 0.01 & 0.01 & 0.02 & 0.01 & 0.07 & 0.02 & 0.01 & 0.01 & 0.02 & 0.01 & 0.01 \\
\hline $\mathrm{Fe}$ & 0.77 & 0.76 & 0.88 & 0.66 & 0.63 & 0.85 & 1.08 & 1.09 & 0.75 & 1.11 & 0.57 & 0.88 & 1.29 & 0.91 & 0.79 & 0.91 & 0.94 & 1.05 & 1.00 & 0.39 \\
\hline $\mathrm{Mn}$ & 0.03 & 0.02 & 0.02 & 0.02 & 0.02 & 0.03 & 0.03 & 0.04 & 0.02 & 0.04 & 0.02 & 0.03 & 0.04 & 0.02 & 0.02 & 0.03 & 0.03 & 0.03 & 0.03 & 0.02 \\
\hline $\mathrm{Mg}$ & 1.50 & 1.33 & 1.76 & 2.02 & 2.06 & 1.72 & 1.57 & 1.58 & 1.94 & 1.59 & 1.73 & 1.81 & 1.39 & 1.77 & 1.90 & 1.75 & 1.77 & 1.62 & 1.66 & 1.09 \\
\hline $\mathrm{Ca}$ & 0.74 & 0.92 & 0.39 & 0.35 & 0.36 & 0.45 & 0.42 & 0.36 & 0.36 & 0.34 & 0.74 & 0.35 & 0.37 & 0.36 & 0.33 & 0.33 & 0.34 & 0.36 & 0.35 & 1.54 \\
\hline $\mathrm{Na}$ & 0.00 & 0.00 & 0.00 & 0.00 & 0.00 & 0.00 & 0.00 & 0.00 & 0.00 & 0.00 & 0.00 & 0.00 & 0.00 & 0.00 & 0.00 & 0.01 & 0.00 & 0.00 & 0.00 & 0.00 \\
\hline sum & 8.0 & 8.0 & 8.0 & 8.0 & 8.0 & 8.0 & 8.0 & 8.0 & 8.0 & 8.0 & 8.0 & 8.0 & 8.0 & 8.0 & 8.0 & 8.00 & 8.0 & 8.0 & 8.0 & 8.0 \\
\hline pyrope & 0.52 & 0.45 & 0.62 & 0.70 & 0.71 & 0.59 & 0.55 & 0.56 & 0.68 & 0.55 & 0.59 & 0.63 & 0.50 & 0.60 & 0.64 & 0.62 & 0.62 & 0.57 & 0.58 & 0.37 \\
\hline almand & 0.25 & 0.25 & 0.28 & 0.21 & 0.20 & 0.28 & 0.36 & 0.36 & 0.24 & 0.36 & 0.18 & 0.29 & 0.43 & 0.31 & 0.26 & 0.30 & 0.30 & 0.35 & 0.33 & 0.12 \\
\hline grossular & 0.23 & 0.30 & 0.10 & 0.09 & 0.09 & 0.13 & 0.10 & 0.08 & 0.08 & 0.08 & 0.23 & 0.09 & 0.08 & 0.10 & 0.10 & 0.08 & 0.08 & 0.08 & 0.09 & 0.51 \\
\hline $\mathrm{Mg \#}$ & 0.66 & 0.64 & 0.67 & 0.75 & 0.77 & 0.67 & 0.59 & 0.59 & 0.72 & 0.59 & 0.75 & 0.67 & 0.52 & 0.66 & 0.71 & 0.66 & 0.65 & 0.61 & 0.62 & 0.74 \\
\hline
\end{tabular}

Table 2 Major element compositions of clinopyroxene from all eclogite paragenesis determined by EPMA.

\begin{tabular}{|c|c|c|c|c|c|c|c|c|c|c|c|c|c|c|c|c|c|c|c|c|}
\hline $\operatorname{cpx}$ & $\begin{array}{c}\mathrm{Z} 184 \\
\text { bi }\end{array}$ & $\begin{array}{c}\text { Z323 } \\
\text { bi }\end{array}$ & $\begin{array}{c}\mathrm{Z} 257 \\
\text { bi } \\
\end{array}$ & $\begin{array}{c}\text { Z298 } \\
\text { bi } \\
\end{array}$ & $\begin{array}{c}\text { Z239 } \\
\text { bi }\end{array}$ & $\begin{array}{c}\text { Z263 } \\
\text { opx }\end{array}$ & $\begin{array}{c}\text { Z217 } \\
\text { opx }\end{array}$ & $\begin{array}{c}\text { Z341 } \\
\text { opx }\end{array}$ & $\begin{array}{c}\text { Z469 } \\
\text { opx }\end{array}$ & $\begin{array}{c}\text { Z188 } \\
\text { opx }\end{array}$ & $\begin{array}{c}\text { Z185 } \\
\text { opx }\end{array}$ & $\begin{array}{c}\text { Z175 } \\
\text { opx }\end{array}$ & $\begin{array}{c}\text { Z332 } \\
\text { opx }\end{array}$ & $\begin{array}{c}\text { Z330 } \\
\text { opx }\end{array}$ & $\begin{array}{c}\text { Z291 } \\
\text { opx }\end{array}$ & $\begin{array}{c}\text { Z202 } \\
\text { opx }\end{array}$ & $\begin{array}{c}\text { Z266 } \\
\text { san }\end{array}$ & $\begin{array}{c}\text { Z267 } \\
\text { san }\end{array}$ & $\begin{array}{c}\text { ZKE1 } \\
\text { san }\end{array}$ & $\begin{array}{c}\text { Z356 } \\
\text { ky }\end{array}$ \\
\hline $\mathrm{SiO}_{2}$ & 54.47 & 54.14 & 54.04 & 55.15 & 54.26 & 54.88 & 53.83 & 53.51 & 54.36 & 54.64 & 54.87 & 54.98 & 53.84 & 54.81 & 55.21 & 54.12 & 54.46 & 53.98 & 54.32 & 52.91 \\
\hline $\mathrm{TiO}_{2}$ & 0.06 & 0.07 & 0.23 & 0.08 & 0.11 & 0.09 & 0.14 & 0.15 & 0.21 & 0.18 & 0.04 & 0.11 & 0.11 & 0.16 & 0.11 & 0.08 & 0.08 & 0.11 & 0.11 & 0.01 \\
\hline $\mathrm{Al}_{2} \mathrm{O}_{3}$ & 5.74 & 8.69 & 3.17 & 3.59 & 2.78 & 4.32 & 1.79 & 2.58 & 2.99 & 3.35 & 8.06 & 3.06 & 2.55 & 3.05 & 3.47 & 3.39 & 2.80 & 2.69 & 2.84 & 11.47 \\
\hline $\mathrm{Cr}_{2} \mathrm{O}_{3}$ & 0.11 & 0.23 & 0.18 & 0.09 & 0.33 & 0.14 & 0.25 & 0.07 & 0.15 & 0.15 & 0.11 & 0.22 & 0.05 & 0.85 & 0.36 & 0.17 & 0.15 & 0.18 & 0.15 & 0.08 \\
\hline $\mathrm{FeO}$ & 3.02 & 2.80 & 4.34 & 3.64 & 3.11 & 3.97 & 5.97 & 7.07 & 4.37 & 6.56 & 1.82 & 4.03 & 7.61 & 4.34 & 3.55 & 4.46 & 4.52 & 6.55 & 5.01 & 1.13 \\
\hline $\mathrm{MnO}$ & 0.04 & 0.04 & 0.06 & 0.06 & 0.04 & 0.06 & 0.07 & 0.12 & 0.05 & 0.11 & 0.01 & 0.07 & 0.11 & 0.05 & 0.06 & 0.10 & 0.08 & 0.12 & 0.09 & 0.03 \\
\hline $\mathrm{NiO}$ & 0.04 & 0.04 & 0.05 & - & 0.07 & - & 0.07 & 0.03 & 0.09 & - & 0.08 & 0.07 & 0.04 & 0.08 & 0.10 & 0.04 & 0.04 & 0.05 & 0.05 & 0.05 \\
\hline $\mathrm{MgO}$ & 13.80 & 11.88 & 15.12 & 15.34 & 16.04 & 14.44 & 15.38 & 14.64 & 15.44 & 14.39 & 13.04 & 15.53 & 14.19 & 14.99 & 15.40 & 15.28 & 15.53 & 14.26 & 15.20 & 11.46 \\
\hline $\mathrm{CaO}$ & 20.30 & 18.59 & 20.33 & 20.49 & 21.13 & 19.94 & 20.56 & 19.58 & 20.59 & 18.86 & 19.34 & 20.32 & 19.15 & 19.57 & 20.11 & 19.69 & 19.95 & 18.78 & 20.12 & 19.03 \\
\hline $\mathrm{Na}_{2} \mathrm{O}$ & 2.46 & 3.47 & 1.96 & 2.31 & 1.71 & 2.63 & 1.39 & 2.14 & 2.11 & 2.57 & 3.01 & 1.87 & 1.89 & 2.20 & 2.01 & 2.04 & 1.82 & 2.48 & 1.85 & 3.54 \\
\hline $\mathrm{K} 2 \mathrm{O}$ & 0.01 & 0.01 & 0.01 & 0.00 & 0.01 & 0.01 & 0.01 & 0.01 & 0.01 & 0.01 & 0.02 & 0.01 & 0.01 & 0.03 & 0.02 & 0.01 & 0.02 & 0.05 & 0.02 & 0.02 \\
\hline total & 100 & 100 & 99 & 101 & 100 & 100 & 99 & 100 & 100 & 101 & 100 & 100 & 100 & 100 & 100 & 99 & 99 & 99 & 100 & 100 \\
\hline $\mathrm{Si}$ & 1.96 & 1.94 & 1.97 & 1.97 & 1.96 & 1.97 & 1.98 & 1.95 & 1.96 & 1.97 & 1.95 & 1.98 & 1.98 & 1.98 & 1.99 & 1.97 & 1.98 & 1.98 & 1.97 & 1.89 \\
\hline $\mathrm{Ti}$ & 0.00 & 0.00 & 0.01 & 0.00 & 0.00 & 0.00 & 0.00 & 0.00 & 0.01 & 0.00 & 0.00 & 0.00 & 0.00 & 0.00 & 0.00 & 0.00 & 0.00 & 0.00 & 0.00 & 0.00 \\
\hline $\mathrm{Al}$ & 0.24 & 0.37 & 0.14 & 0.15 & 0.12 & 0.18 & 0.08 & 0.11 & 0.13 & 0.1 & 0.3 & 0.1 & 0.11 & 0.13 & 0.15 & 0.15 & 0.12 & 0.12 & 0.12 & 0.48 \\
\hline $\mathrm{Cr}$ & 0.00 & 0.01 & 0.01 & 0.00 & 0.01 & 0.00 & 0.01 & 0.00 & 0.00 & 0.0 & 0.0 & 0.01 & 0.00 & 0.02 & 0.01 & 0.00 & 0.00 & 0.01 & 0.00 & 0.00 \\
\hline $\mathrm{Fe}$ & 0.09 & 0.08 & 0.13 & 0.11 & 0.09 & 0.12 & 0.18 & 0.22 & 0.13 & 0.20 & 0.0 & 0.12 & 0.23 & 0.13 & 0.11 & 0.14 & 0.14 & 0.20 & 0.15 & 0.03 \\
\hline $\mathrm{Mn}$ & 0.00 & 0.00 & 0.00 & 0.00 & 0.00 & 0.00 & 0.00 & 0.00 & 0.00 & 0.00 & 0.00 & 0.00 & 0.00 & 0.00 & 0.00 & 0.00 & 0.00 & 0.00 & 0.00 & 0.00 \\
\hline $\mathrm{Ni}$ & 0.00 & 0.00 & 0.00 & 0.00 & 0.00 & 0.00 & 0.00 & 0.00 & 0.00 & 0.00 & 0.00 & 0.00 & 0.00 & 0.00 & 0.00 & 0.00 & 0.00 & 0.00 & 0.00 & 0.00 \\
\hline $\mathrm{Mg}$ & 0.74 & 0.63 & 0.82 & 0.82 & 0.87 & 0.77 & 0.84 & 0.80 & 0.83 & 0.77 & 0.69 & 0.83 & 0.78 & 0.81 & 0.83 & 0.83 & 0.84 & 0.78 & 0.82 & 0.61 \\
\hline $\mathrm{Ca}$ & 0.78 & 0.71 & 0.79 & 0.78 & 0.82 & 0.77 & 0.81 & 0.76 & 0.79 & 0.73 & 0.74 & 0.79 & 0.75 & 0.76 & 0.77 & 0.77 & 0.78 & 0.74 & 0.78 & 0.73 \\
\hline $\mathrm{Na}$ & 0.17 & 0.24 & 0.14 & 0.16 & 0.12 & 0.18 & 0.10 & 0.15 & 0.15 & 0.18 & 0.2 & 0.13 & 0.13 & 0.15 & 0.14 & 0.14 & 0.13 & 0.18 & 0.13 & 0.25 \\
\hline sum & 4.0 & 4.0 & 4.0 & 4.0 & 4.0 & 4.0 & 4.0 & 4.0 & 4.0 & 4.0 & 4.0 & 4.0 & 4.0 & 4.0 & 4.0 & 4.0 & 4.0 & 4.0 & 4.0 & 4.0 \\
\hline $\mathrm{Al}[4]$ & 0.04 & 0.06 & 0.03 & 0.03 & 0.04 & 0.03 & 0.02 & 0.05 & 0.04 & 0.03 & 0.05 & 0.02 & 0.02 & 0.02 & 0.01 & 0.03 & 0.02 & 0.02 & 0.03 & 0.11 \\
\hline $\mathrm{Al}[6]$ & 0.21 & 0.31 & 0.10 & 0.12 & 0.08 & 0.15 & 0.05 & 0.06 & 0.08 & 0.11 & 0.29 & 0.11 & 0.09 & 0.11 & 0.13 & 0.11 & 0.10 & 0.09 & 0.10 & 0.37 \\
\hline diopside & 0.40 & 0.38 & 0.40 & 0.40 & 0.41 & 0.39 & 0.41 & 0.39 & 0.40 & 0.37 & 0.39 & 0.40 & 0.38 & 0.39 & 0.39 & 0.39 & 0.39 & 0.38 & 0.40 & 0.39 \\
\hline heden. & 0.45 & 0.42 & 0.48 & 0.46 & 0.48 & 0.45 & 0.50 & 0.48 & 0.47 & 0.47 & 0.44 & 0.48 & 0.50 & 0.48 & 0.48 & 0.48 & 0.49 & 0.47 & 0.49 & 0.41 \\
\hline jadeite & 0.15 & 0.20 & 0.12 & 0.14 & 0.11 & 0.16 & 0.09 & 0.13 & 0.13 & 0.15 & 0.17 & 0.12 & 0.12 & 0.13 & 0.12 & 0.13 & 0.11 & 0.15 & 0.12 & 0.20 \\
\hline $\mathrm{Mg} \#$ & 0.89 & 0.88 & 0.86 & 0.88 & 0.90 & 0.87 & 0.82 & 0.79 & 0.86 & 0.80 & 0.93 & 0.87 & 0.77 & 0.86 & 0.89 & 0.86 & 0.86 & 0.80 & 0.84 & 0.95 \\
\hline
\end{tabular}




\begin{tabular}{|c|c|c|c|c|c|c|c|c|c|c|c|c|c|c|c|}
\hline \multirow[t]{2}{*}{ Table 3} & \multicolumn{15}{|c|}{$\begin{array}{l}\text { Major element compositions of accessories including orthopyroxenes, sanidine and kyanite from eclogites determined by } \\
\text { EPMA. }\end{array}$} \\
\hline & $\begin{array}{c}\text { Z341 } \\
\text { opx }\end{array}$ & $\begin{array}{c}\text { Z469 } \\
\text { opx }\end{array}$ & $\begin{array}{c}\mathrm{Z188} \\
\text { opx }\end{array}$ & $\begin{array}{c}\mathrm{Z175} \\
\text { opx }\end{array}$ & $\begin{array}{c}\mathrm{Z332} \\
\text { opx }\end{array}$ & $\begin{array}{c}\text { Z330 } \\
\text { opx }\end{array}$ & $\begin{array}{c}\text { Z291 } \\
\text { opx }\end{array}$ & $\begin{array}{c}\mathrm{Z} 202 \\
\text { opx }\end{array}$ & $\begin{array}{c}\text { Z266 } \\
\text { opx }\end{array}$ & $\begin{array}{c}\text { Z267 } \\
\text { opx }\end{array}$ & $\begin{array}{c}\text { ZKE1 } \\
\text { opx }\end{array}$ & $\begin{array}{c}\mathrm{Z} 267 \\
\text { san }\end{array}$ & $\begin{array}{c}\text { ZKE1 } \\
\text { san }\end{array}$ & $\begin{array}{c}\mathrm{Z} 356 \\
\text { san }\end{array}$ & $\begin{array}{c}\text { Z356 } \\
\text { ky }\end{array}$ \\
\hline $\mathrm{SiO}_{2}$ & 53.69 & 56.47 & 55.84 & 57.24 & 54.61 & 56.41 & 56.47 & 53.69 & 56.14 & 56.01 & 55.99 & 63.73 & 64.44 & 61.60 & 37.03 \\
\hline $\mathrm{TiO}_{2}$ & 0.06 & 0.10 & 0.06 & 0.06 & 0.05 & 0.09 & 0.03 & 0.06 & 0.03 & 0.03 & 0.04 & 0.01 & 0.01 & 0.02 & 0.01 \\
\hline $\mathrm{Al}_{2} \mathrm{O}_{3}$ & 0.89 & 0.92 & 0.87 & 0.82 & 0.81 & 0.84 & 0.95 & 0.89 & 0.77 & 0.76 & 0.75 & 18.73 & 17.82 & 19.34 & 62.48 \\
\hline $\mathrm{Cr}_{2} \mathrm{O}_{3}$ & 0.02 & 0.02 & 0.03 & 0.02 & 0.02 & 0.14 & 0.05 & 0.02 & 0.03 & 0.03 & 0.02 & 0.00 & 0.01 & 0.00 & 0.14 \\
\hline $\mathrm{FeO}$ & 14.39 & 8.62 & 13.93 & 10.48 & 16.65 & 10.80 & 9.06 & 14.39 & 11.17 & 12.54 & 12.08 & 0.11 & 0.23 & 0.02 & 0.09 \\
\hline MnO & 0.24 & 0.12 & 0.19 & 0.08 & 0.20 & 0.12 & 0.10 & 0.24 & 0.15 & 0.19 & 0.16 & 0.00 & 0.00 & 0.02 & 0.02 \\
\hline $\mathrm{NiO}$ & 0.07 & 0.22 & 0.00 & 0.13 & 0.08 & 0.17 & 0.19 & 0.07 & 0.09 & 0.11 & 0.11 & 0.00 & 0.00 & 0.00 & 0.00 \\
\hline MgO & 29.30 & 33.60 & 29.58 & 31.87 & 27.38 & 31.51 & 32.15 & 29.30 & 31.27 & 30.73 & 30.73 & 0.01 & 0.35 & 0.00 & 0.02 \\
\hline $\mathrm{CaO}$ & 0.47 & 0.36 & 0.46 & 0.37 & 0.54 & 0.48 & 0.51 & 0.47 & 0.44 & 0.42 & 0.45 & 0.02 & 0.53 & 0.04 & 0.04 \\
\hline $\mathrm{Na}_{2} \mathrm{O}$ & 0.08 & 0.07 & 0.09 & 0.09 & 0.11 & 0.18 & 0.08 & 0.08 & 0.08 & 0.08 & 0.08 & 0.61 & 0.48 & 0.84 & 0.01 \\
\hline $\mathbf{K}_{2} \mathbf{O}$ & - & - & - & - & - & - & - & - & - & - & - & 16.10 & 15.81 & 13.87 & 0.01 \\
\hline $\mathrm{BaO}$ & - & - & - & - & - & - & - & - & - & - & - & 0.00 & 0.19 & 4.57 & 0.01 \\
\hline sum & 99.24 & 100.53 & 101.05 & 101.17 & 100.47 & 100.86 & 99.62 & 99.24 & 100.19 & 100.92 & 100.45 & 99.34 & 99.88 & 100.30 & 99.86 \\
\hline $\mathbf{S i}$ & 1.93 & 1.95 & 1.97 & 1.99 & 1.96 & 1.97 & 1.98 & 1.93 & 1.97 & 1.97 & 1.97 & 2.96 & 2.99 & 2.92 & 1.00 \\
\hline $\mathbf{T i}$ & 0.00 & 0.00 & 0.00 & 0.00 & 0.00 & 0.00 & 0.00 & 0.00 & 0.00 & 0.00 & 0.00 & 0.00 & 0.00 & 0.00 & 0.00 \\
\hline Al & 0.04 & 0.04 & 0.04 & 0.03 & 0.03 & 0.03 & 0.04 & 0.04 & 0.03 & 0.03 & 0.03 & 1.03 & 0.97 & 1.08 & 1.99 \\
\hline $\mathrm{Cr}$ & 0.00 & 0.00 & 0.00 & 0.00 & 0.00 & 0.00 & 0.00 & 0.00 & 0.00 & 0.00 & 0.00 & 0.00 & 0.00 & 0.00 & 0.00 \\
\hline $\mathrm{Fe}$ & 0.43 & 0.25 & 0.41 & 0.30 & 0.50 & 0.32 & 0.27 & 0.43 & 0.33 & 0.37 & 0.36 & 0.00 & 0.01 & 0.00 & 0.00 \\
\hline Mn & 0.01 & 0.00 & 0.01 & 0.00 & 0.01 & 0.00 & 0.00 & 0.01 & 0.00 & 0.01 & 0.00 & 0.00 & 0.00 & 0.00 & 0.00 \\
\hline $\mathbf{N i}$ & 0.00 & 0.01 & 0.00 & 0.00 & 0.00 & 0.00 & 0.01 & 0.00 & 0.00 & 0.00 & 0.00 & 0.00 & 0.00 & 0.00 & 0.00 \\
\hline Mg & 1.57 & 1.73 & 1.55 & 1.65 & 1.47 & 1.64 & 1.68 & 1.57 & 1.64 & 1.61 & 1.61 & 0.00 & 0.02 & 0.00 & 0.00 \\
\hline $\mathrm{Ca}$ & 0.02 & 0.01 & 0.02 & 0.01 & 0.02 & 0.02 & 0.02 & 0.02 & 0.02 & 0.02 & 0.02 & 0.00 & 0.03 & 0.00 & 0.00 \\
\hline $\mathrm{Na}$ & 0.01 & 0.00 & 0.01 & 0.01 & 0.01 & 0.01 & 0.01 & 0.01 & 0.01 & 0.01 & 0.01 & 0.05 & 0.04 & 0.08 & 0.00 \\
\hline $\mathbf{K}$ & - & - & - & - & - & - & - & - & - & - & - & 0.95 & 0.93 & 0.84 & 0.00 \\
\hline $\mathbf{B a}$ & - & - & - & - & - & - & - & - & - & - & - & 0.00 & 0.01 & 0.18 & 0.00 \\
\hline sum & 4.0 & 4.0 & 4.0 & 4.0 & 4.0 & 4.0 & 4.0 & 4.0 & 4.0 & 4.0 & 4.0 & 5.0 & 5.0 & 5.1 & 3.0 \\
\hline Mg\# & 0.78 & 0.87 & 0.79 & 0.84 & 0.75 & 0.84 & 0.86 & 0.78 & 0.83 & 0.81 & 0.82 & 15.94 & 15.96 & 15.83 & 10.00 \\
\hline
\end{tabular}

Table 4 Reconstructed whole rock major element compositions of eclogites determined by electron probe. Modal proportions were estimated optically for the bimineralic eclogites $(40 \mathrm{wt} \% \mathrm{gt}$ and $60 \mathrm{wt} \% \mathrm{cpx}$ ) and for all polyphase eclogites with the electron microprobe from re-integration of element maps and phase map analyses (opx-bearing eclogites: $37 \mathrm{wt} \% \mathrm{gt}$, and $58 w t \%$ cpx, 5 wt\% opx; sanidine eclogites: 3 wt \% gt, and 62 wt\% cpx, 4 wt\% opx, 1 wt\% sanidine; kyanite eclogite: 15 $w t \%$ gt, $76 w t \%$ cpx, $8 w t \%$ kyanite, 1 wt\% sanidine).

\begin{tabular}{|c|c|c|c|c|c|c|c|c|c|c|c|c|c|c|c|c|c|c|c|c|}
\hline & $\begin{array}{r}\mathbf{Z 1 8 4} \\
\text { bimin. }\end{array}$ & $\begin{array}{l}\mathbf{Z 3 2 3} \\
\text { bimin. } \\
\text { 40wt } \%\end{array}$ & 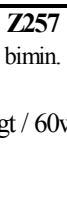 & $\begin{array}{l}\mathbf{Z 2 9 8} \\
\text { bimin. } \\
\% \text { cpx }\end{array}$ & $\begin{array}{r}\mathbf{Z 2 3 9} \\
\text { bimin. }\end{array}$ & $\begin{array}{c}\mathbf{Z 2 6 3} \\
\text { орx }\end{array}$ & \multicolumn{10}{|c|}{$37 \mathrm{wt} \% \mathrm{gt} / 58 \mathrm{wt} \% \mathrm{cpx} / 5 \mathrm{wt} \%$ opx } & \multicolumn{3}{|c|}{$\begin{array}{c}\text { Z266 } \\
\text { Z267 }\end{array}$} & \begin{tabular}{|c|}
$\mathbf{Z 3 5 6}$ \\
$\mathrm{ky}$ \\
$15 \mathrm{wt} \% \mathrm{gt}$
\end{tabular} \\
\hline $\begin{array}{c}\text { incl. in gt } \\
\text { incl. in cpx } \\
\text { texture }\end{array}$ & $\begin{array}{l}- \\
-\end{array}$ & - & $\begin{array}{c}\overline{-} \\
\text { rut }\end{array}$ & $\begin{array}{c}\overline{-} \\
\text { rut }\end{array}$ & $\begin{array}{c}- \\
- \\
\text { cum }\end{array}$ & $\begin{array}{c}- \\
\text { rut }\end{array}$ & $\begin{array}{l}\text { ilm } \\
\text { ilm }\end{array}$ & $\begin{array}{l}- \\
-\end{array}$ & $\begin{array}{c}- \\
- \\
\text { cum }\end{array}$ & $\begin{array}{c}- \\
\text { rut } \\
\text { cum }\end{array}$ & $\begin{array}{l}\text { rut,qu } \\
\text { rut } \\
\text { cum }\end{array}$ & $\begin{array}{l}\text { rut,qu } \\
\text { rut }\end{array}$ & $\begin{array}{c}\text { rut,qu } \\
\text { rut }\end{array}$ & $\begin{array}{l}\text { rut,qu } \\
\text { rut }\end{array}$ & $\begin{array}{l}\text { rut,qu } \\
\text { rut }\end{array}$ & $\begin{array}{c}\text { rut,qu } \\
\text { rut }\end{array}$ & $\begin{array}{l}\text { ru } \\
\text { rut }\end{array}$ & $\begin{array}{c}\text { qu,cpx } \\
\text { rut }\end{array}$ & rut & $\begin{array}{c}- \\
\text { cum }\end{array}$ \\
\hline $\mathrm{SiO2}$ & 49.2 & 48.8 & 48.9 & 50.1 & 49.4 & 50.0 & 49.0 & 48.7 & 49.7 & 49.7 & 49.9 & 50.1 & 50.1 & 48.8 & 50.3 & 49.5 & 50.2 & 49.7 & 50.1 & 49.9 \\
\hline $\mathrm{TiO} 2$ & 0.05 & 0.06 & 0.19 & 0.07 & 0.09 & 0.06 & 0.13 & 0.12 & 0.17 & 0.13 & 0.13 & 0.03 & 0.09 & 0.10 & 0.09 & 0.07 & 0.07 & 0.10 & 0.09 & 0.01 \\
\hline Al2O3 & 12.5 & 14.3 & 11.1 & 11.6 & 10.9 & 11.1 & 9.0 & 9.9 & 10.3 & 10.4 & 9.9 & 13.3 & 10.2 & 9.7 & 10.5 & 10.7 & 9.4 & 9.3 & 9.5 & 17.3 \\
\hline $\mathrm{Cr} 2 \mathrm{O3}$ & 0.10 & 0.23 & 0.22 & 0.10 & 0.36 & 0.14 & 0.41 & 0.09 & 0.18 & 0.14 & 0.95 & 0.11 & 0.24 & 0.07 & 0.37 & 0.20 & 0.17 & 0.20 & 0.17 & 0.09 \\
\hline $\mathrm{FeO}$ & 6.88 & 6.61 & 8.37 & 6.64 & 6.06 & 8.15 & 10.57 & 11.41 & 7.58 & 11.20 & 8.60 & 5.19 & 8.21 & 12.92 & 7.36 & 8.72 & 8.34 & 10.20 & 9.01 & 1.82 \\
\hline MnO & 0.19 & 0.16 & 0.19 & 0.18 & 0.14 & 0.24 & 0.22 & 0.33 & 0.15 & 0.30 & 0.17 & 0.13 & 0.20 & 0.29 & 0.16 & 0.21 & 0.21 & 0.26 & 0.22 & 0.07 \\
\hline $\mathrm{NiO}$ & 0.03 & 0.03 & 0.03 & 0.00 & 0.04 & 0.01 & 0.05 & 0.02 & 0.07 & 0.00 & 0.06 & 0.06 & 0.05 & 0.03 & 0.07 & 0.03 & 0.03 & 0.04 & 0.04 & 0.04 \\
\hline MgO & 13.8 & 12.0 & 15.6 & 16.9 & 17.4 & 15.8 & 15.8 & 15.3 & 17.4 & 15.2 & 16.3 & 15.1 & 16.8 & 14.3 & 17.1 & 16.3 & 16.3 & 15.0 & 15.7 & 10.2 \\
\hline $\mathrm{CaO}$ & 16.0 & 15.9 & 14.2 & 14.2 & 14.6 & 13.7 & 13.9 & 13.1 & 13.7 & 12.6 & 13.1 & 14.8 & 13.5 & 12.9 & 13.3 & 12.9 & 13.8 & 13.2 & 14.0 & 17.4 \\
\hline $\mathrm{Na} 2 \mathrm{O}$ & 1.48 & 2.09 & 1.19 & 1.39 & 1.03 & 1.54 & 0.82 & 1.25 & 1.24 & 1.50 & 1.29 & 1.76 & 1.10 & 1.11 & 1.18 & 1.32 & 1.14 & 1.55 & 1.16 & 2.70 \\
\hline $\mathrm{K} 2 \mathrm{O}$ & 0.02 & 0.01 & 0.01 & 0.00 & 0.01 & 0.01 & 0.01 & 0.01 & 0.01 & 0.01 & 0.02 & 0.01 & 0.01 & 0.01 & 0.01 & 0.01 & 0.17 & 0.19 & 0.17 & 0.16 \\
\hline $\mathrm{BaO}$ & 0.01 & 0.01 & 0.00 & 0.00 & 0.00 & 0.00 & 0.01 & 0.02 & 0.01 & 0.00 & 0.02 & 0.02 & 0.01 & 0.00 & 0.02 & 0.01 & 0.02 & 0.00 & 0.02 & 0.06 \\
\hline total & 100 & 100 & 100 & 101 & 100 & 101 & 100 & 100 & 101 & 101 & 100 & 101 & 100 & 100 & 101 & 100 & 100 & 100 & 100 & 100 \\
\hline Mg\# & 0.80 & 0.78 & 0.78 & 0.83 & 0.85 & 0.79 & 0.74 & 0.71 & 0.81 & 0.72 & 0.79 & 0.86 & 0.80 & 0.67 & 0.82 & 0.78 & 0.78 & 0.73 & 0.76 & 0.83 \\
\hline
\end{tabular}


The chemical similarity of granular and lamellar garnets in addition to the lack of chemical changes within garnet grains and exsolution lamellae is a sharing feature of all eclogite types suggesting the formation of each garnet lamella under constant conditions. Nevertheless, the lack of diffusion gradients in clinopyroxene and garnet, which is proved for all eclogite types by back scattered images (Fig. 7b, 8b, 9a, 9b) and line profiles imply that the exsolution went to completion. Zonings in the euhedral garnets are lacking, though they show abundant inclusions in cores with inclusion-free rims, which implies that the garnets are chemically balanced in spite of the textural disequilibrium indicated by the inclusions. The latter fact argues against different garnet generations and for a long period of reequilibration probably at high temperatures.

\section{Compared to eclogitic} garnets from Siberian- and Kaapvaal craton kimberlites, most Zero eclogite garnets are rather $\mathrm{Ca}$-poor and plot in the lower part of the $\mathrm{MgO}-\mathrm{FeO}-\mathrm{CaO}$ triangle. Exceptions are the garnets from the bimineralic eclogites Z185 and Z323, which plot in the middle of the garnet field and span generally the widest range in composition and $\mathrm{Mg \# .} \mathrm{It} \mathrm{appears} \mathrm{as} \mathrm{if} \mathrm{the} \mathrm{chemical}$ composition of the bimineralic eclogites is affected by the extent of garnet exsolution from clinopyroxene. Hence, sample Z323, which shows abundant thin closely spaced exsolution lamellae (Fig. 7a, b) with approximately equal proportions between the lamellae, has the highest jadeite and grossular contents. Thus it might be that exsolved garnets becomes progressively more grossularrich during the course of exsolution (Harte and Gurney, 1975). Exceptionally different occurs the grossular from the grospydite Z356, which plot outside the composition field for kyanite eclogites and grospydites
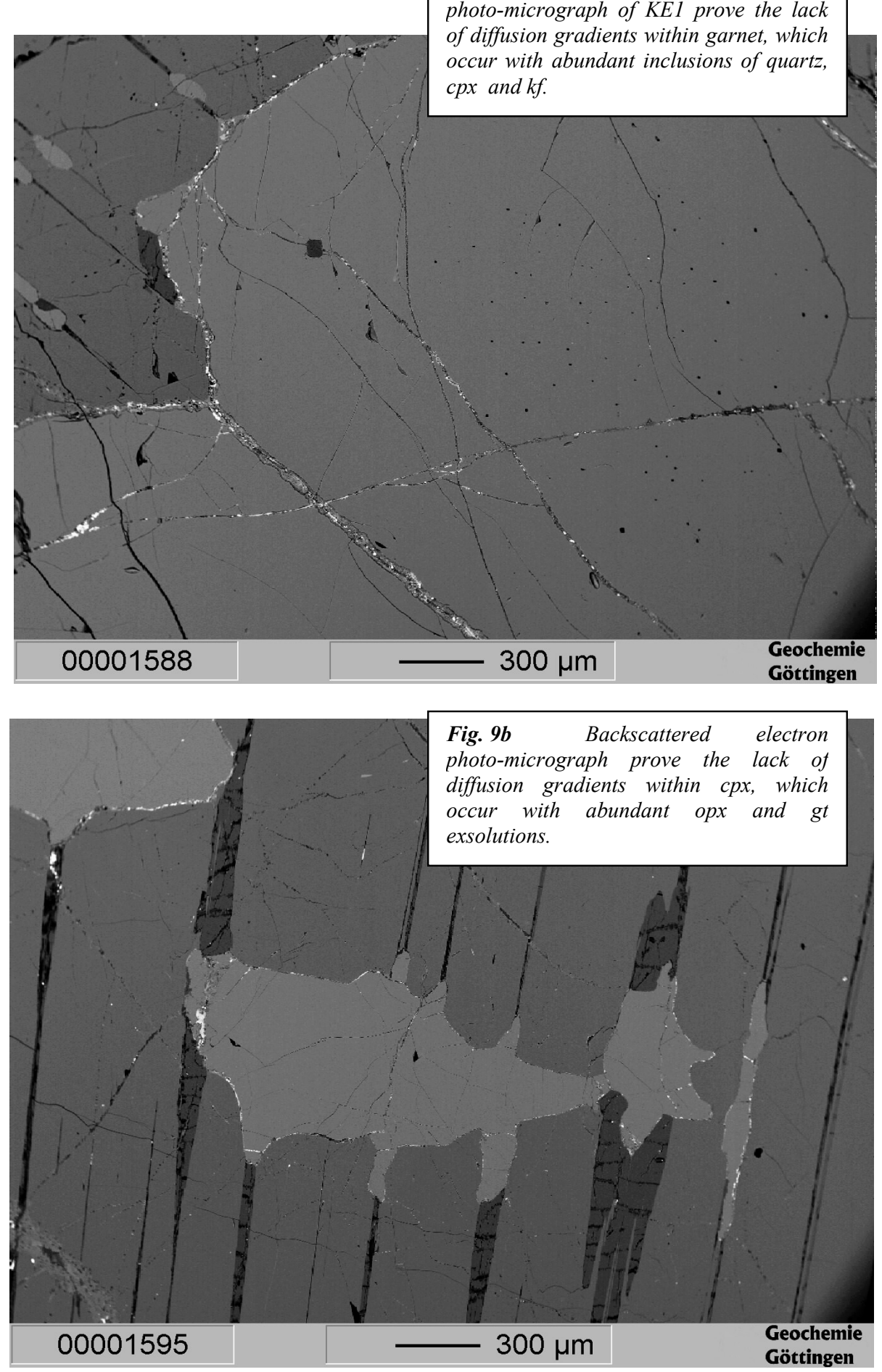
from the Siberia- and Kaapvaal craton, caused by the very low $\mathrm{FeO}$ content ( $1.5 \mathrm{wt} \%)$. 
Beyond the lack of plagioclase and olivine, the jadeite content distinguishes eclogites from Tschermak's rich pyroxenites. Therefore, the site of $\mathrm{Al}$ is crucial for the eclogite classification. Since $\mathrm{Al}_{2} \mathrm{O}_{3}$ correlates with $\mathrm{Na}_{2} \mathrm{O}$ content rather than with $\mathrm{CaO}$, the jadeite content $\mathrm{Al}^{(\mathrm{VI})}$ of Zero eclogites is evidenced. The latter observation is consistent with the low amount of

Tschermak's

component, which

varies in the bimineralic eclogites and the kyanite grospydite Z356 from 6-11 wt $\%$ and shows values less than 1 $\mathrm{wt} \% \quad \mathrm{Al}^{(\mathrm{IV})}$ in the remaining eclogites. Thus, according to the ratio of $\mathrm{Jd} / \mathrm{Ts}>2: 1$, which is used to distinguish eclogites from pyroxenites (Aoki and Shiba, 1973) most

Zero xenoliths can definitely be considered as eclogites with the exceptions of Z217, Z341 and Z469 (Fig. 10). Since the latter xenoliths occur at the

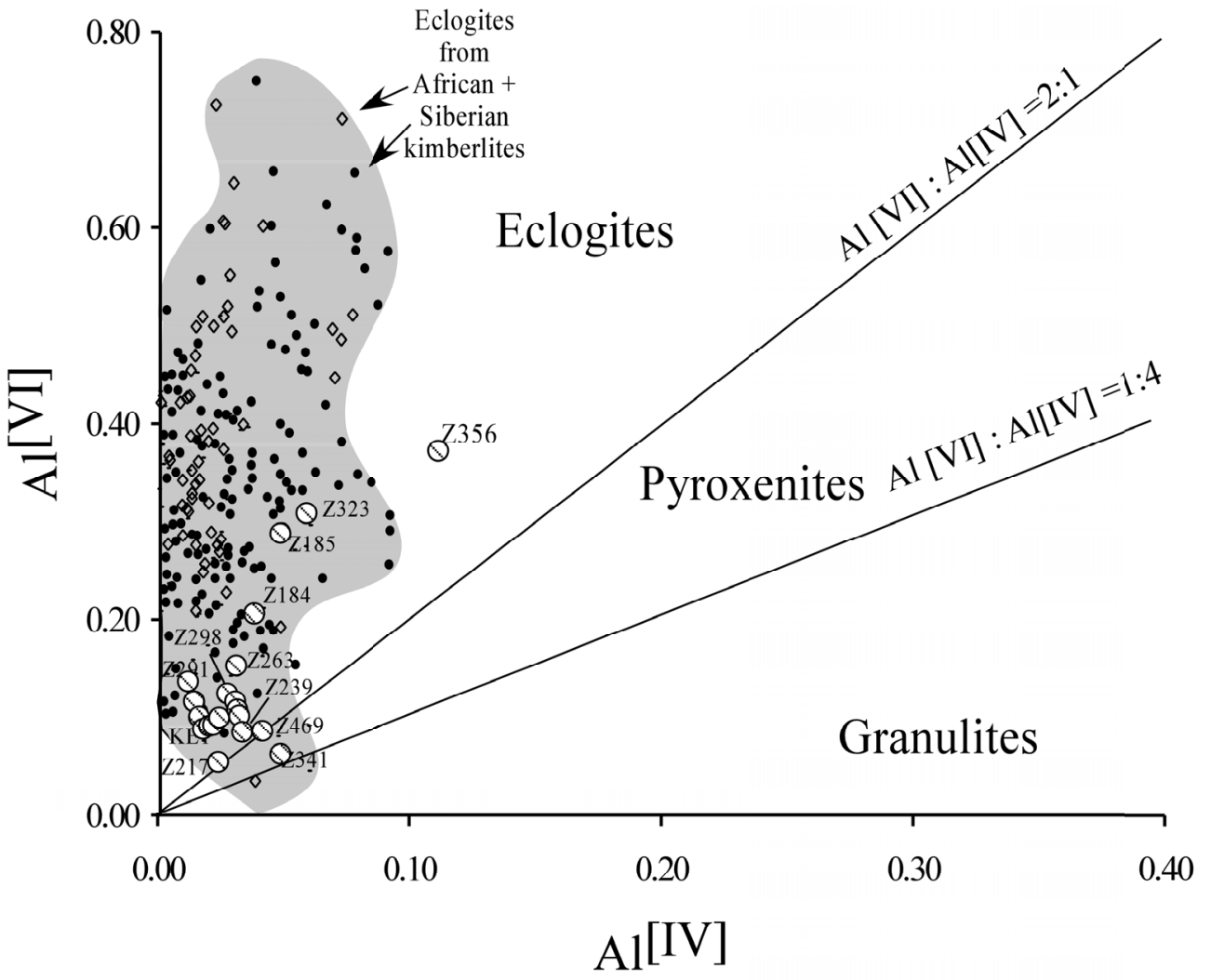

Fig. $10 \quad$ With the eclogite classification suggested by Aoki and Shiba (1973), which based on the coordination of Al, eclogites can be distinguished from pyroxenites. According to this classification, most Zero eclogites are to consider as eclogites except sample Z341, Z217 and Z469, which plot on the border or within the pyroxenite field.

edge of the eclogite

field, they should be considered as pyroxenites. Compared to jadeite-rich clinopyroxenes from different eclogite xenolith suites from the Kaapvaal craton (Roberts Victor, Koidu, Bellsbank \pm 24 mol\% jadeite) and Siberian craton (Udachnaya, Zagadochnaya, Mir; \pm 28 mol\% jadeite) most Zero eclogite omphacites occur with lower $\mathrm{Na}_{2} \mathrm{O}(1.3-2.6 \mathrm{wt} \%)$ and jadeite contents $(9-15 \mathrm{~mol} \%$ ). The kyanite grospydite Z356 and the bimineralic specimen Z323 represent with 20 mol\% the jadeite rich exceptions. In terms of the high $\mathrm{MgO}$ with low $\mathrm{Na}_{2} \mathrm{O}$ contents all Zero eclogites can be classified as Group A-B eclogites (Coleman et al., 1965, Taylor, 1989). With respect to the low $\mathrm{Na}_{2} \mathrm{O}$ content in garnet $(<0.09$ wt $\%)$ and $\mathrm{K}_{2} \mathrm{O}$ content in clinopyroxene $(<0.08 \mathrm{wt} \%)$, which are crucial indicators for a high-pressure derivation, the Zero eclogites are defined as group II eclogites (McCandless and Gurney, 1986), which are distinguished from group I eclogites with higher values. Nevertheless, the $\mathrm{K}_{2} \mathrm{O}$ content of clinopyroxene in equilibrium with sanidine exsolutions is with $40 \mathrm{ppm}$ rather low (but reasonable at prevailing conditions, $\mathrm{Na}_{2} \mathrm{O}$ in garnet was not detectable. The $\mathrm{MnO}$ and $\mathrm{TiO}_{2}$ levels are below $0.2 \mathrm{wt} \%$ in garnets and clinopyroxene of all eclogites though the $\mathrm{TiO}_{2}$ values are maximum values without an estimation of rutile inclusions. Furthermore, the $\mathrm{Cr}_{2} \mathrm{O}_{3}$ content of most eclogites is limited $\left( \pm 0.19 \mathrm{wt} \% \mathrm{Cr}_{2} \mathrm{O}_{3}\right)$ except in samples $\mathrm{Z330}$, Z217 and $\mathrm{Z} 239$, which occur with higher values of $0.4-1.7 \mathrm{wt} \% \mathrm{Cr}_{2} \mathrm{O}_{3}$ in garnet and $0.25-0.8 \mathrm{wt} \% \mathrm{Cr}_{2} \mathrm{O}_{3}$ in clinopyroxene. Trace elements are negligible in all phases, with the exception of the accessory sanidine from the kyanite grospydite Z356, which has $4.5 \mathrm{wt} \% \mathrm{BaO}$ and is thus to consider as a Ba-feldspar. 


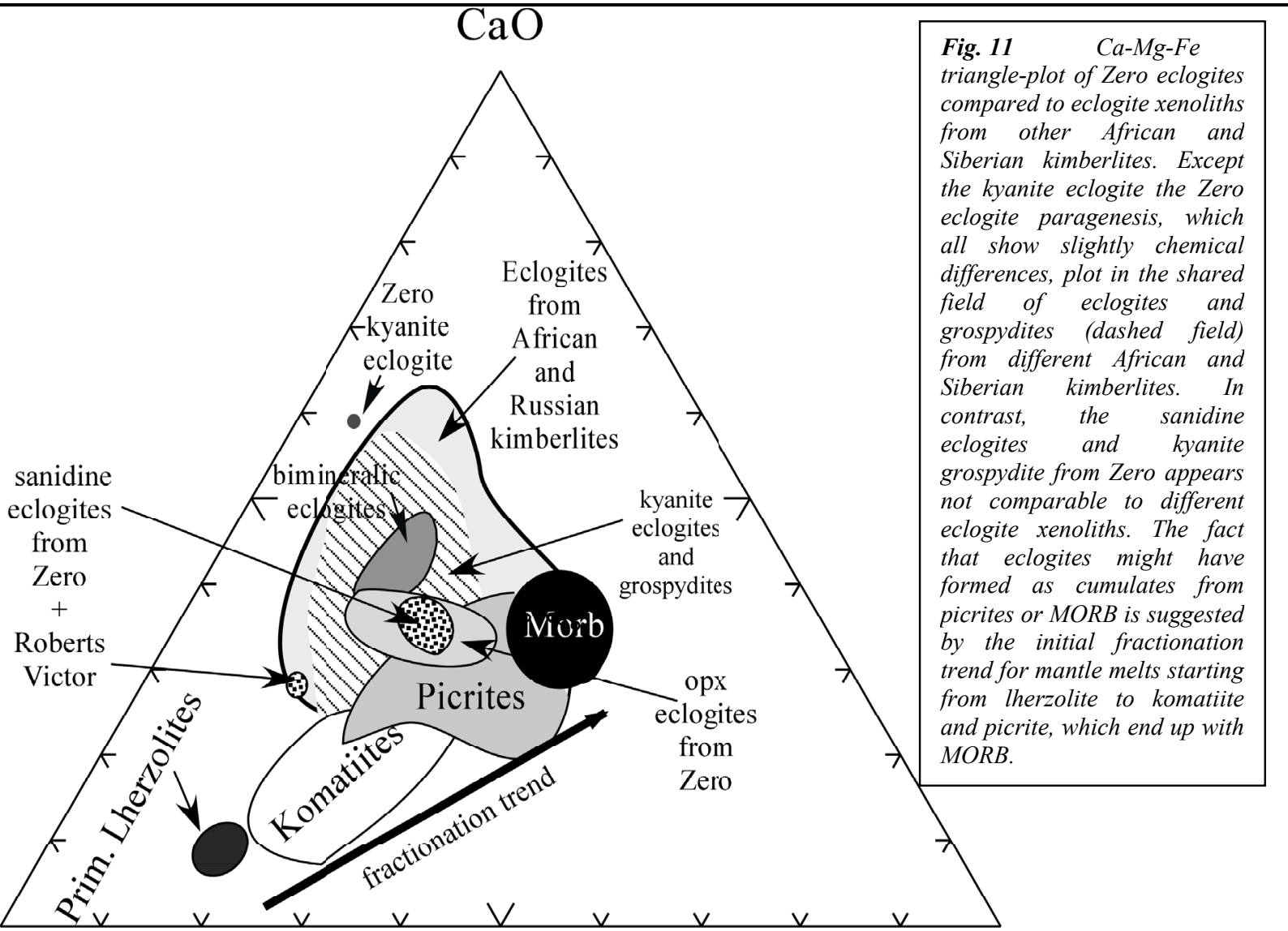

$\mathrm{MgO}$

$\mathrm{FeO}_{\text {tot }}$

\subsection{Thermobarometry}

Since eclogite xenoliths from most kimberlites are essentially bimineralic, the applied geo-thermometers are restricted to clinopyroxene-garnet pairs. The currently best-constrained thermometers for bimineralic eclogites are based on different calibrations of the temperature dependent distribution of $\mathrm{Fe} / \mathrm{Mg}$ between garnet and clinopyroxene (Krogh, 1988; Ellis and Green, 1979; Brey and Köhler, 1986) though it was originally intended for garnet peridotites. According to a recent assessment (Taylor, 1998) Krogh's (Krogh, 1988) calibration reproduces experimental temperatures of peridotitic compositions best though the Ellis and Green (1979) calibration is frequently used for abundant bimineralic eclogites and has thus the widest prevalence in the literature. Although almost every calculation is susceptible to compositional uncertainties (Taylor, 1998), which might yield unpredictable variations, the reliability of the $\mathrm{Fe}^{2+} / \mathrm{Mg}^{2+}$ exchange temperatures is reduced by the uncertainty associated with $\mathrm{Fe}^{3+} / \mathrm{Fe}_{\text {tot }}$ estimation. The latter calculation of $\mathrm{Fe}^{3+} / \mathrm{Fe}_{\text {tot }}$ requires a perfect stoichiometry, and this cannot be assessed by microprobe data alone. However, since $\mathrm{Fe}^{3+} / \mathrm{Fe}_{\text {tot }}$ ratios are typically higher in clinopyroxene than in garnet, the use of $\mathrm{Fe}^{2+}=\mathrm{Fe}_{\mathrm{tot}}-\mathrm{Fe}^{3+}$ atomic fractions in thermometric calculations will provide minimum temperatures. If all iron accommodated in clinopyroxene is taken as ferrous, the temperatures may be on average $100^{\circ} \mathrm{C}$ higher than temperatures estimated without calculated $\mathrm{Fe}^{2+} / \mathrm{Fe}_{\mathrm{tot}}$. The presence of orthopyroxene in the Zero eclogites enables the application of calibrations of the temperature dependent $\mathrm{Ca}$ partitioning between clinopyroxene and orthopyroxene or the orthopyroxene solvus alone, which becomes narrower as temperature increases (Brey et al., 1986; Brey and Köhler, 1990; Nickel and Green, 1985). Due to the fact that a barometer can not be applied for nondiamondiferous bimineralic eclogites, pressure conditions are usually estimated by projecting the clinopyroxene and garnet temperatures onto the continental geotherm, which is either calculated or described by associated peridotite xenoliths. If 
orthopyroxene is present the partitioning of Al between orthopyroxene and garnet, which occurs as a function of pressure can be used as barometer (Nickel and Green, 1985, Brey and Köhler, 1990) according the reaction:

$$
\mathrm{Mg}_{2} \mathrm{Si}_{2} \mathrm{O}_{6}+\mathrm{MgAlAISiO}_{6} \Leftrightarrow \mathrm{Mg}_{3} \mathrm{Al}_{2}\left(\mathrm{SiO}_{4}\right)_{3}
$$

\subsection{Evaluation of previous $P / T$ conditions}

Enabled through the occurrence of orthopyroxene, different thermometers and barometers were used to judge previous equilibration conditions for the Zero eclogites. Depending on the constituents, the Fe/ $\mathrm{Mg}$ thermometer calibrated by Ellis and Green (1979) was used for all eclogites, whereas the $\mathrm{Ca}$ thermometer and the $\mathrm{Al}$ in orthopyroxene barometer was used for the orthopyroxene bearing eclogites.

temperature $\left[{ }^{\circ} \mathrm{C}\right]$

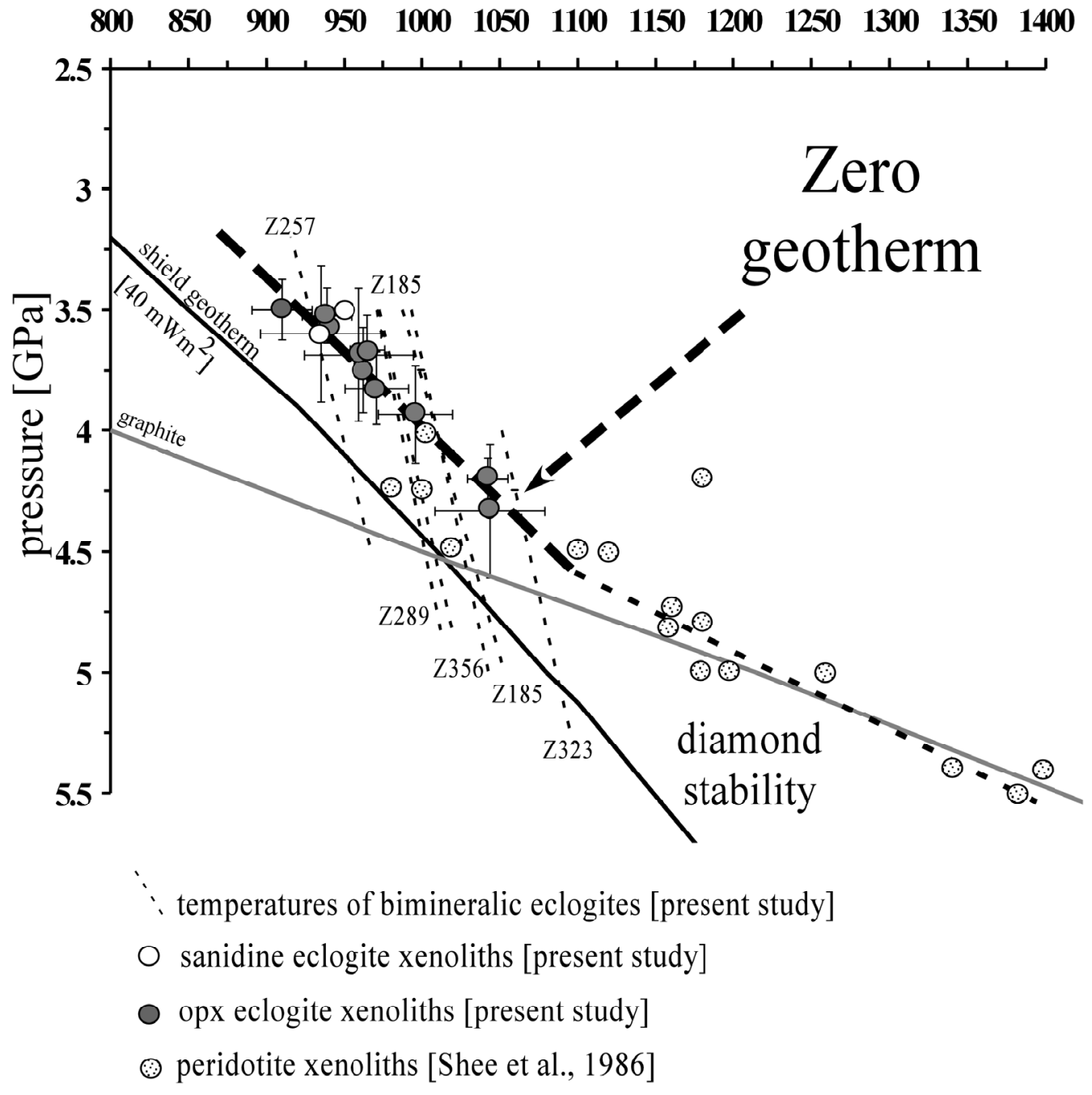

Fig. 12 PT-plot of the Zero xenoliths show the last conditions of the eclogites prior to the kimberlite eruption. Plotted are intersections of temperatures, which based on Fe/Mg exchange between cpx and gt calibrated by Krogh (1988) and pressures estimated from Al content in opx, calibrated by Brey and Köhler (1990). Error bars are illustrated, not for accuracy, but for those samples that showed a wide discrepancy between temperatures calculated with total ferrous and $\mathrm{Fe}^{2+}$ to emphasize a feasible range of PT-conditions from which the eclogites might be derived. The Zero geotherm described by the PT conditions of the xenoliths (marked by the dashed black line through the samples) appears slightly above the shield geotherm $\left(40 \mathrm{mWm} \mathrm{m}^{2}\right)$ from Pollack and Chapman (1977) in consistence to the relatively hot geotherm described by peridotite xenoliths from the Zero kimberlite (Shee et al. 1986), previously. 
On the strength of the chemical equilibration achieved in the eclogites, average major element data were applied for the evaluation of previous P-T estimates, and give values in the range $\mathrm{T}=930-950^{\circ} \mathrm{C}$ at $\mathrm{P}=3.5-4.0 \mathrm{GPa}$ for most eclogites. Since the $\mathrm{Fe} / \mathrm{Mg}$ exchange thermometer is dependent on the $\mathrm{Fe}^{3+}$ contents, temperatures were calculated either with $\mathrm{Fe}_{\mathrm{tot}}$ or $\mathrm{Fe}^{2+}$

$\left(\mathrm{Fe}^{2+}=\mathrm{Fe}_{\text {tot }}-\mathrm{Fe}^{3+}\right)$. The estimated temperatures of all eclogites at $3.5 \mathrm{GPa}$ span a wide range from $711^{\circ} \mathrm{C}$ to $1090^{\circ} \mathrm{C}$ with all $\mathrm{Fe}$ in the ferrous state $\left(\mathrm{Fe}^{2+} / \mathrm{Mg}^{2+}\right)$ and 752 to $1084^{\circ} \mathrm{C}$ with $\mathrm{Fe}_{\text {tot }}$, whereas $\mathrm{Ca}$ in orthopyroxene show values between 752 and $1088^{\circ} \mathrm{C}$. In most eclogites, the temperatures estimated with the Ca-thermometer, which is assumed to be more appropriate to peridotites compared to $\mathrm{Fe} / \mathrm{Mg}$ temperatures, show a correlation with the Fe/Mg temperatures estimated with Fe as total ferrous (Z188, Z263, Z266, ZKE1). Otherwise, the Ca in orthopyroxene temperatures fall within the gap between the E\&G temperatures with $\mathrm{Fe}_{\text {tot }}$ and $\mathrm{Fe}^{2+}$. Thus, the use of reduced $\mathrm{Fe}^{2+}$ for the calculation evidently yields minimal temperatures. Nevertheless, a considerable amount of $\mathrm{Fe}^{3+}$, which is usually higher in clinopyroxene than in garnet, increases the uncertainty of the calculated temperatures. The temperature differences between the distinct approaches are given in table 4 for each sample. The intersections of pressures and temperatures yield a slightly higher geothermal gradient (Fig. 12) for the eclogites than the calculated $40 \mathrm{~mW} / \mathrm{m}^{2}$ shield geotherm (Pollack and Chapman, 1977); this is consistent with the geothermal gradient ascertained on peridotite xenoliths from the Zero kimberlite (Shee et al., 1986). Two bimineralic eclogites (Z323 and Z184), the orthopyroxene eclogite Z291 and the kyanite eclogite Z356 show slightly higher temperatures in contrast to the remaining eclogites. In a plot comparing the latter samples with the estimated pressures for the orthopyroxene bearing eclogites, a slightly greater depth is implied. Following the common procedure of plotting the Fe/Mg temperatures on the assumed shield geotherm $\left(40 \mathrm{~mW} / \mathrm{m}^{2}\right)$ would even imply pressures within the diamond stability field.

\subsection{Determination of the garnet inclusions using Raman Spectroscopy}

Mainly small quartz but also rare K-feldspar and clinopyroxene inclusions enclosed in garnet grains, situated beneath the sample surface, have been identified with in-situ Raman-spectroscopy, equipped with the laser technique. Ramanspectroscopy has been used widely to distinguish between $\mathrm{SiO}_{2}$ polymorphs, on the basis of characteristic Raman spectra. Thus quartz, which consists of 4 modes $\left(202.5,355,462,1085 \mathrm{~cm}^{-1}\right.$; Fig. 13a) at atmospheric pressure (Dean et al., 1982) can be distinguished from coesite, which occurs with 5 bands $\left(205,271,355,425,521 \mathrm{~cm}^{-1 ;}\right.$ Fig. 13a). Since Raman lines react sensitively to pressure and temperature effects they yield decisive information on the compressed state of a mineral and the pressure condition, which may be determined by shifts to different wave numbers (Sobolev and Shatsky, 1990). Using Raman spectroscopy $\alpha$-quartz inclusions were detected in garnets, though with respect to the prevailing $\mathrm{P} / \mathrm{T}$ condition $\left( \pm 950^{\circ} \mathrm{C},<4 \mathrm{GPa}\right)$ coesite was anticipated to be stabile, since quartz transforms to coesite between $800^{\circ} \mathrm{C}$ and $1400^{\circ} \mathrm{C}$ at 2.5-3.0 GPa (Akaogi et al., 1995). Compared to Raman lines from non-deformed $\alpha$-quartz the detected Raman frequencies deviate moderately and are shifted to wave numbers $227.2,354.8$ and $472.2 \mathrm{~cm}^{-1}$ (13, bottom). Pressure conditions can be calculated using the measured frequency shifts of the most pressure sensitive 206 and $464 \mathrm{~cm}^{-1}$ Raman lines from the frequencies at ambient conditions. Applying the shift barometer (Schmidt and Ziemann, 2000) the frequency shift to 227.2 $\mathrm{cm}^{-1}$ implies that the internal pressure for the quartz inclusions within the sanidine eclogite ZKE1 corresponds to $9 \mathrm{~kb}$ at $24^{\circ} \mathrm{C}$ (R. Thomas, pers. comm.). Unfortunately, due to non-linear temperature dependence, the shift barometer is calibrated only near room temperatures, but provided that the crystallization temperature was considerably higher elevated pressure can be assumed. However, a well-calibrated isochore for the quartz/coesite phase transition does not yet exist. 
However, the question whether the modified Raman lines towards high-pressure conditions might imply that previously existing coesite or stishoevite transformed into quartz remains unanswered. Against this presumption might argue that the inclusions occur without decompression cracks at their grain boundaries, which are commonly described from different coesite eclogites (Mosenfelder, 1997). However, the lack of transformation cracks can be attributed to the small inclusion size, between 5 to $10 \mu \mathrm{m}$ in diameter, so that they could not generate sufficient tension through phase transition to rupture the garnets. Nevertheless, the survival of coesite is generally linked to its inclusion in phases that can sustain a high internal pressure during decompression, and to entirely dry conditions (Mosenfelder, 1997), since the availability of several ppm fluid promotes the rapid transformation.

Although the $\mathrm{SiO}_{2}$ inclusions should be preserved as high-pressure modification it is likely that they changed into quartz from coesite or stishoevite during the period around $1.6 \mathrm{Ga}$.
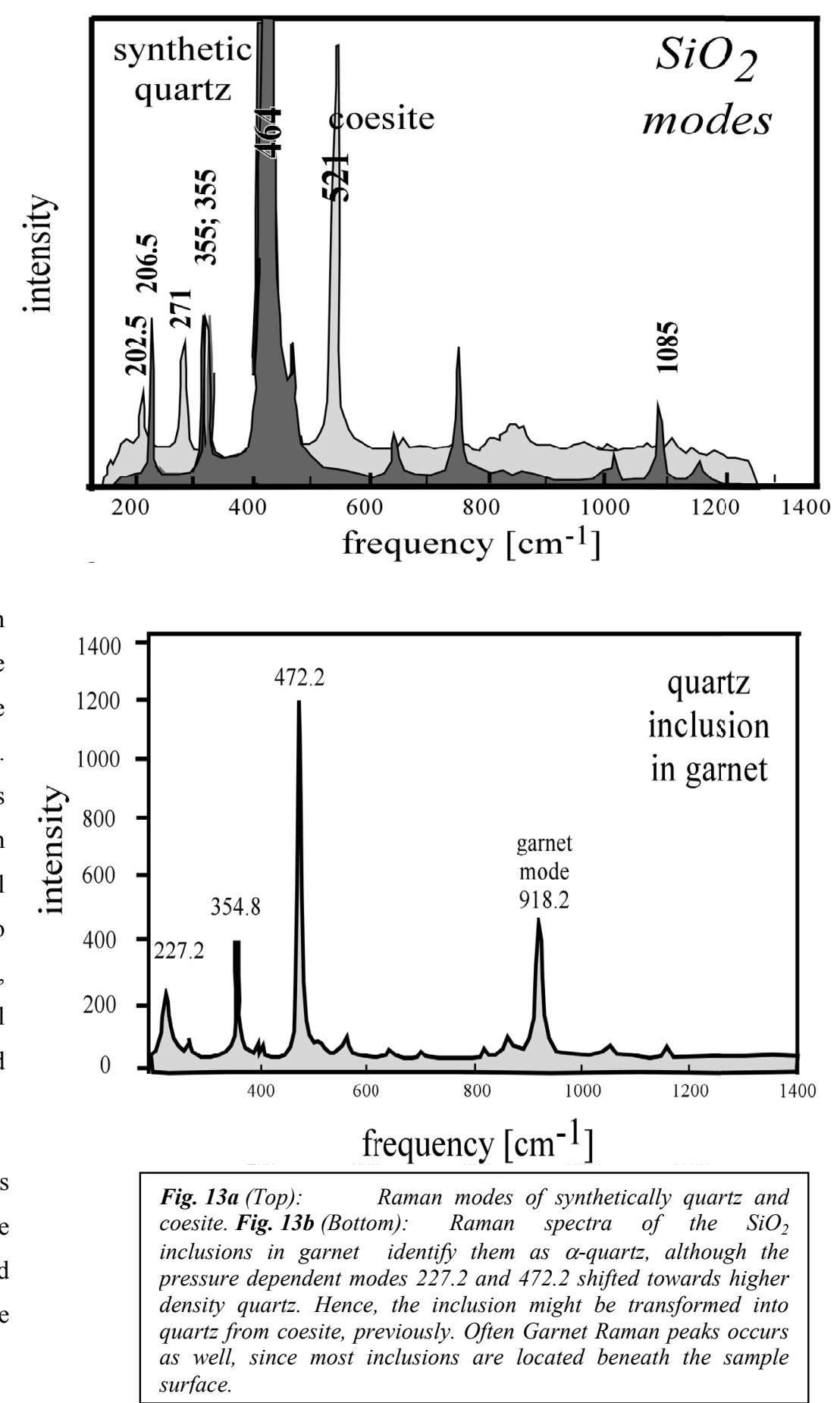

\subsection{Oxygen isotopic compositions of the Zero eclogites}

Laser fluorination oxygen isotope data of garnet and coexisting clinopyroxene were obtained for 2 sanidine eclogites (Z267, ZKE1), 2 orthopyroxene eclogites (Z291, Z469) and 2 bimineralic samples (Z257, Z239) summarized in table 5. Unfortunately, for analytical reasons it was not possible to analyze the kyanite grospydite Z356. The eclogites show $\delta^{18} \mathrm{O}$ values of 5.08 to $5.51 \%$ for clinopyroxene and 5.15 to $5.57 \%$ for garnet and have a mean value of $5.3 \%$ t \pm 0.09 for clinopyroxene and $5.36 \% \pm 0.09$ for garnet. Hence all measured $\delta^{18} \mathrm{O}$ values fall within the narrow range for the uncontaminated mantle and signify mantle derivation. The deviation between clinopyroxene and garnet is with $0.04 \%$ on average rather small. Although the fractionation under equilibrium conditions between clinopyroxene and garnet is anticipated to be positive (Gregory and Taylor, 1986; Rosenbaum et al., 1994) most Zero samples show inverse 
fractionation. This might be due to the insignificant fractionation between clinopyroxene and garnet (near to zero) and thus the fractionation merely appears as negative but occurs within the error range of 0.13 to $0.15 \%$. A reasonable explanation for the narrow fractionation between both constituents might be due to that garnet exsolved from clinopyroxene in different crystal orientations. Thus, in spite of careful mineral separation, exsolved micro-garnets remained within clinopyroxene crystals and therefore clinopyroxene, which should be enriched in $\delta^{18} \mathrm{O}$ compared to lighter garnet, might be less enriched due to small amount of lighter garnet within the clinopyroxene.

\begin{tabular}{|cc|cc|cc|}
\hline \multicolumn{2}{|c|}{ sanidine-bearing eclogites } & \multicolumn{2}{|c|}{ opx-bearing eclogites } & \multicolumn{2}{|c|}{ bimineralic eclogites } \\
\hline \hline & & & & \\
sample & $\boldsymbol{\delta}^{\mathbf{1 8}} \mathbf{O}$ & sample & $\boldsymbol{\delta}^{\mathbf{1 8}} \mathbf{O}$ & sample & $\boldsymbol{\delta}^{\mathbf{1 8}} \mathbf{O}$ \\
\hline \multirow{2}{*}{ ZKE1 cpx } & 5.19 & Z469 cpx & 5.35 & Z257 cpx & 5.30 \\
ZKE1 gt & 5.18 & Z469 gt & 5.45 & Z257 gt & 5.35 \\
& & & & & \\
Z267 cpx & 5.21 & Z291 cpx & 5.19 & Z239 cpx & 5.39 \\
Z267 gt & 5.27 & Z291 gt & 5.22 & Z239 gt & 5.47 \\
\hline
\end{tabular}

Table 5 Oxygen isotopes of garnet and cpx from sanidine eclogites, opx-bearing eclogites and bimineralic eclogites.

\section{Discussion}

Since whole rock analyses of xenoliths generally suffer from kimberlitic infiltration effects (Barth et al., 2001), the bulk compositions were calculated using the mineral analyses in modal proportions. Whole rock compositions for bimineralic eclogites (table 4) were calculated using modal proportions estimated by optical microscopy (40\% cpx and $60 \%$ gt). Modal proportions of orthopyroxene (37\% gt, 58\% clinopyroxene, 5\% orthopyroxene) and sanidine eclogites (33\% gt, 62\% clinopyroxene, $4 \%$ orthopyroxene, $1 \%$ san) were determined by phase map analysis of element mappings performed by EPMA (Zack, 2000). Variations in whole rock chemistry are reflected in different garnet compositions of different eclogite types range from $\mathrm{Py}_{71} \mathrm{Al}_{20} \mathrm{Gr}_{09}$ to $\mathrm{Py}_{37} \mathrm{Al}_{12} \mathrm{Gr}_{51}$.

The whole rock compositions of the eclogites span a wide range in $\mathrm{MgO}$ content between $10 \mathrm{wt} \%$ - > $17 \mathrm{wt} \%$ and $\mathrm{Mg \#}$ between 67 and 83 and thus are not generally divisible into high and low $\mathrm{MgO}$ eclogites, as described from eclogite xenoliths from the Koidu kimberlite (Barth et al., 2001). In terms

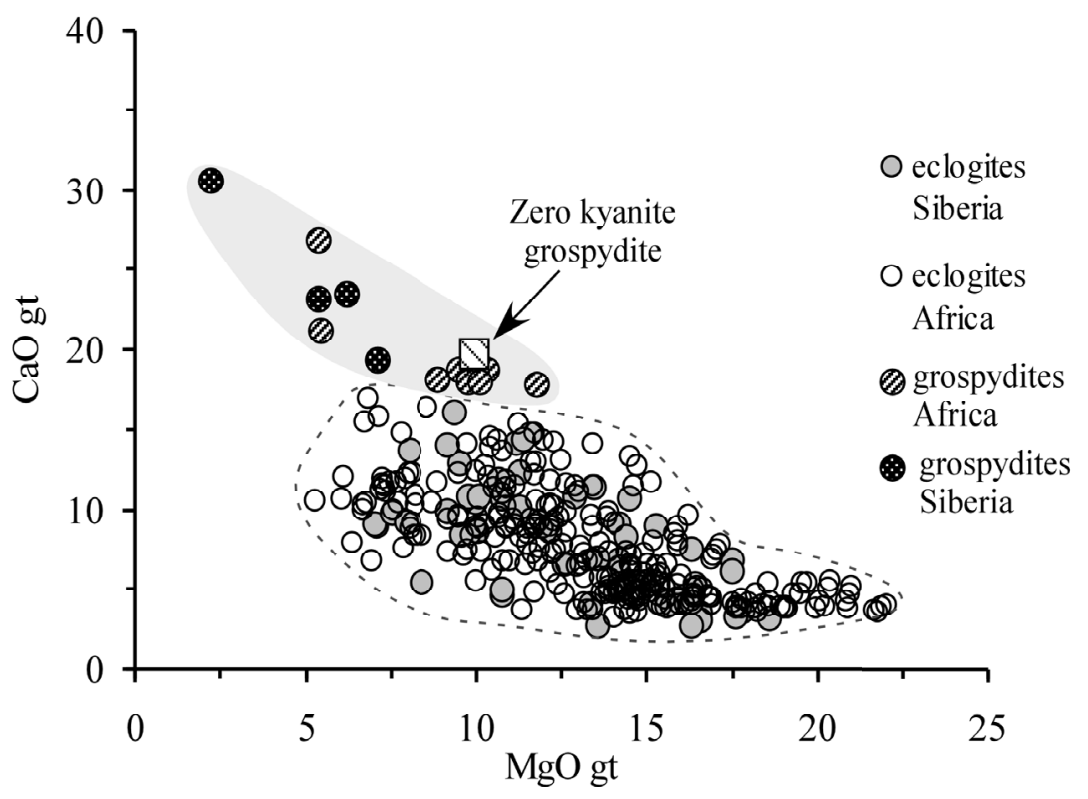

Fig. 14 Plot of $\mathrm{CaO}$ versus $\mathrm{MgO}$ of garnets from grospydites and eclogites from different kimberlites. 
of $\mathrm{MgO} / \mathrm{CaO}$ ratios, two different bimineralic eclogite types can be distinguished. Whereas the bimineralic eclogites $\mathrm{Z323}$ and Z184 occur with the lowest MgO contents (12 - 13 wt\%), bimineralic samples Z257, Z239 and Z298 show higher values (15 $17 \mathrm{wt} \%$ ) rather comparable to $\mathrm{MgO}$ rich orthopyroxene bearing samples Z469 and Z291 ( $<17 \mathrm{wt} \%)$. The kyanite grospydite show the lowest $\mathrm{MgO}$ content (10 wt\%), caused by the increased grossular contentbut has the highest $\mathrm{Mg \# ,} \mathrm{due} \mathrm{to} \mathrm{the}$ unusually low $\mathrm{FeO}$ content. The remaining bimineralic eclogites and orthopyroxene eclogites show intermediate $\mathrm{MgO}$ contents (13-15 wt \%).

\subsection{The source for "mantle eclogites" is still enigmatic}

In the research of the source of eclogite xenoliths, oxygen isotopes have a key position as fingerprints for near surface processes, judging a low-pressure origin for them. The fractionation of oxygen isotopes occurs mainly as a function of temperature, whereas the pressure dependence is negligibly small ( $<2 \%$; Clayton et al., 1975). The fractionation of oxygen isotopes at low temperatures is most significant, so that they give an excellent indication for near-surface processes. The fractionation under mantle temperatures is restricted and the majority of clinopyroxene from peridotite xenoliths shows $\delta^{18} \mathrm{O}$ values of $5.57 \pm 0.36 \%$ (Mattey et al., 1994). However, most $\delta^{18} \mathrm{O}$ values of all known eclogite xenoliths fall outside the peridotite range and are similar to $\delta^{18} \mathrm{O}$ values found in ophiolites that have been subjected to hydrothermal alteration (Alt, 1995; Muehlenbachs, 1986). As on ophiolite profiles, the occurrence of eclogites showing mantle like $\delta^{18} \mathrm{O}$ values may not completely exclude seawater alteration of the protoliths. Hence, oxygen isotopes are the most reliable tracers if deviating $\delta^{18} \mathrm{O}$ values occur, since these can only be produced at near-surface conditions and proving definitely hydrothermal activity in a crustal precursor (Jagoutz et al., 1984; Garlick et al., 1971; MacGregor and Carter, 1970; MacGregor and Manton, 1986; Jacob et al., 1994). In contrast, in the case of the Zero eclogites, the unique occurrence of exclusively mantle-like $\delta^{18} \mathrm{O}$ values (about 5.1-5.5\%) does not prove or disprove a high-pressure origin, since hydrothermal activity within ophiolites and thus the $\delta^{18} \mathrm{O}$ profiles with depth is still not well understood.

Nevertheless, the occurrence of quartz and K-feldspar in most Zero eclogites might appear as evidence for a recycled origin since partial melts from peridotite should not be saturated in quartz at any pressure higher than $8 \mathrm{GPa}$ (Green and Falloon, 1998), and these constituents are generally assumed not to be primary components of the Earth's mantle. Currently, the occurrence of quartz and sanidine in eclogites is supposed to be produced by metamorphism of seawater-altered crust formed by the reaction: plagioclase $\rightarrow$ jadeite $+\mathrm{SiO}_{2}$ or by metasomatism at a late stage. The exsolution of $\mathrm{SiO}_{2}$ from initial majorite-component would be possible but can be excluded since garnet does not show silica in excess and is also unlikely due to the exceptionally high-pressure conditions required (above $12 \mathrm{GPa}$ ), corresponding to a depth near the transition zone. For phase-petrologic reasons these so called "mantle eclogites" are still enigmatic, since they are discussed as high pressure cumulates crystallized within the upper mantle from peridotite generated magmas (O'Hara and Yoder, 1967; MacGregor and Carter, 1970). Although high-pressure experiments proved that eclogites could have been generated from partial melts of peridotite (Takahashi, 1986), melting of peridotite at high-pressure does not produce basaltic melts (Falloon and Green, 1988). Considering that eclogite xenoliths are frequently associated with diamond partial melting of peridotite must occur at pressures exceeding 3.5 GPa, which is not a feasible process for producing bimineralic eclogites, since such high-pressure generated melts become increasingly $\mathrm{MgO}$ rich with increasing pressure and would crystallize into an assemblage containing olivine. One interpretation explained garnet and clinopyroxene as cumulates, whereas olivine crystallization was prevented through reaction with the residual melt (Hatton and Gurney, 1987). Furthermore, olivine-free bimineralic eclogites can not be generated by fractional crystallization of garnet lherzolite melts, since the eutectic solidus melting reaction of olivine + garnet + clinopyroxene would produce melts at pressures exceeding $3.3 \mathrm{GPa}$, which shifts to 
the peritectic reaction olivine + clinopyroxene + garnet $\rightarrow$ orthopyroxene + melt with increasing melting. Another reason, which argue against the high-pressure derivation is the higher minimum melting temperature of eclogite, compared to garnet lherzolite at $30 \mathrm{kbar}$ (O'Hara and Yoder, 1967).

\subsection{The origin of different Zero eclogite types}

The restricted isotopic values indicate that the Zero eclogites have probably never been close to the Earth's surface, however, the quartz and K-feldspar inclusions bear witness for derivation from the phlogopite or phengite stability at pressures below $8 \mathrm{GPa}$. In consideration of the latter facts the occurrence of orthopyroxene bearing eclogite xenoliths might argue that the Zero suite represent basal cumulates from an oceanic crust, since orthopyroxene eclogites occur as cyclic units in lower parts of layered intrusions (Irvine, 1970) and cumulate sequences of ophiolites (Jackson et al., 1975). Similar orthopyroxene bearing eclogites, which appear rather rarely in kimberlites, are described from Roberts Victor and Jagersfontein kimberlites (Hatton and Gurney, 1987). However, extensive orthopyroxene exsolution from clinopyroxene has been recognized in granulite xenoliths from the Monastery mine. Similar exsolution features, suggesting a sub-solidus mantle history, were described from orthopyroxene eclogites of the Sunndal-Grubse orogenic terrain (Norwegian Caledonides), which have been interpreted as mantle-derived partial melts (Lappin and Smith, 1977). Rocks similar to the sanidine eclogites showing K-feldspar exsolved from clinopyroxene hosts are also described from Kotchetav diamondiferous rocks (Sobolev and Shatsky, 1990). Subducted K-cpx-rich rocks, formed either as cumulates from phengite and dolomite melting in the down-going slab (such as the Kokchetav garnet clinopyroxenites made up of 70-80 vol.\% of Krich diopside) or through the percolation of UHP K-rich fluids within eclogitic bodies.

In search of a conceivable source for eclogites enriched in orthopyroxene associated with bimineralic eclogites, the disequilibrium evoked through subduction of oceanic crust to eclogite facies conditions and surrounding lherzolite or peridotite might be taken into account (Yaxley and Green, 1998). According to these experiments the migration of andesitic to basaltic partial melts of eclogite bodies entrained into peridotite may cause increasing modal orthopyroxene in the wall rock and can result in a body of bimineralic eclogite mantled by orthopyroxenite or orthopyroxene enriched peridotite, showing lower Mg\# than normal mantle. Similar mineralogical zoning has been described from many peridotite massifs but has generally been attributed to high-pressure crystallization of deeper-derived melts.

Grospydites and kyanite eclogites, which have been described from Bellsbank, Roberts Victor, Bobbejaan, Zagadochnaya and Udachnaya kimberlites, are considered to be late stage differentiates of high-pressure igneous fractional crystallization (Smyth and Caporuscio, 1984) either from primary mantle melts or to be formed by partial melting of subducted material (Harte and Gurney, 1975; Lappin, 1978). The ultimate source for the subducted material has been explained either as high-pressure accumulation of hyper-aluminous clinopyroxene or low-pressure accumulation of plagioclase (Garlick et al., 1971; MacGregor and Carter, 1970; MacGregor and Manton, 1986; Shervais et al., 1988). Justified by the high $\mathrm{Mg} /(\mathrm{Mg}+\mathrm{Fe})$ ratios, the kyanite eclogites were advocated as early accumulation of liquidus pyroxenes followed by re-equilibration by cooling at pressures above 3 GPa (Smyth et al., 1989). According to Lappin (1978) the rarity of the kyanite eclogites compared to bimineralic eclogites, which consisted of Tschermak's rich clinopyroxene, orthopyroxene and kyanite, is due to their being produced from residual, rapidly evolved liquids of small volumes. Similar Ca enrichment has been

suggested to be an igneous trend with some minor sub-solidus adjustment, resulting in the chemical composition of a grospydite was recognized in garnets of the layered eclogites from Roberts Victor. Kyanite eclogites associated with granulites and bimineralic eclogites from Mbuji Mayi kimberlite are interpreted as sampled from the granulite/eclogite transition zone of 
a deep crustal section apparently produced from a plagioclase and Al- rich diopside precursor (Fadili and Demaiffe, 1999). Garnet and kyanite granulites are explained as the lower crustal equivalent of metamorphosed gabbro-norites and anorthosites. Prolonged cooling could have generated different eclogites and thus bimineralic eclogites might be derived from the gabbro noritic precursor whereas kyanite eclogites derived from the plagioclase rich anorthositic precursor (Fadili and Demaiffe, 1999). However due to the lack of experimental evidence for a high-pressure cumulate origin the low pressure derivation is favoured by Jacob et al. (1998) who argued that kyanite eclogite might represent re-crystallized low-pressure Si-Al-rich melts of melted oceanic crust (Jacob and Foley, 1999).

Apart from plagioclase, the protolith of $\mathrm{Z} 356$ was apparently rich in Ca-Eskola end-member $\left(\mathrm{Ca}_{7} \mathrm{Al}_{2} \mathrm{Si}_{4} \mathrm{O}_{12}\right)$, which is indicated by the abundant exsolutions of kyanite. The vacancy abundance indicated by the Ca-Eskola component $\left(\mathrm{Ca}_{0.5} \mathrm{Vac}_{0.5} \mathrm{AlSi}_{2} \mathrm{O}_{6}\right)$, is correlated with pressure and the coexistence of an aluminous phase, such as kyanite, rather than the bulk composition of the assemblage (Harlow, 1999). Since Ca Eskola is unstable below 3 GPa but stabilized at high temperature near the solidus, derivation of the clinopyroxenes at near liquidus temperatures is evidenced. However, the unusual composition of the kyanite eclogite Z356, which shows high Mg\#, appears not to be comparable to kyanite eclogites or grospydites from different kimberlites or to any kind of melt from the mantle. Hence the distinct position of Z356 within the $\mathrm{MgO}-\mathrm{FeO}-\mathrm{CaO}$ plot (Fig. 11) might result from a mixture between primary cumulating and metasomatising melt or was caused by a loss of partial melt after the cumulate formation. The breakdown of plagioclase and primary clinopyroxene rich in Tschermaks component produced kyanite and less aluminous rich clinopyroxene and grossular rich garnet. The Ba-feldspar in sample Z356 might be produced by a metasomatising melt percolating through the xenolith, which is unlikely to be caused by the kimberlitic melt itself since otherwise hydrous minerals would have been produced, but these are lacking in the kyanite eclogite.

\subsection{The mantle history of the eclogites reconstructed on the P-T-t-path of the sanidine eclogites}

Although the initial igneous environment for the eclogites remains to be proved, which is subject of the following study, focusing on thermobarometry (at $\pm 950^{\circ} \mathrm{C} / 3.5 \mathrm{GPa}$ ) and the original $\mathrm{K}_{2} \mathrm{O}$ content of clinopyroxene, a complex mantle history can be inferred from various exsolution reactions of the sanidine eclogites, and these are apparently valid for the complete suite. That eclogites have formed at higher temperatures is implied by garnet and orthopyroxene exsolutions resulting from cooling of Tschermak's rich clinopyroxene enriched in hypersthene (Fujii and Takahashi, 1976). However, the preliminary P-T stage of pre-exsolved homogeneous clinopyroxene can be ascertained on the exsolutions of sanidine from cpx and by referring to the behavior of potassium at mantle conditions. Increased $\mathrm{K}_{2} \mathrm{O}$-contents in clinopyroxene are a crucial indication of high-pressure conditions since $\mathrm{K}_{2} \mathrm{O}$ bearing clinopyroxenes from different parts of the upper mantle, found enclosed in diamonds, have confirmed that $\mathrm{K}$ can be incorporated into the clinopyroxene structure despite the large ionic radius (1.51 $\AA$; Harlow, 1997). Recent high pressure studies on the behavior of $\mathrm{K}_{2} \mathrm{O}$ at mantle conditions established that $\mathrm{K}_{2} \mathrm{O}$ becomes more compatible in clinopyroxene with increasing pressure, which can thus be used as a potential barometer for high-pressure rocks (Schmidt, 1996).

According to multi-anvil melting experiments on $\mathrm{K}_{2} \mathrm{O}$-rich basalts, sanidine breaks down above $6 \mathrm{GPa}$. In the pressure regime up to $10 \mathrm{GPa}$, where the high-pressure phase $\mathrm{K}$-hollandite $\left(\mathrm{KAlSi}_{3} \mathrm{O}_{8}\right.$-phase with hollandite structure) appears, clinopyroxene remains the main $\mathrm{K}_{2} \mathrm{O}$-bearing phase, which $\mathrm{K}_{2} \mathrm{O}$-content increases with proceeding sanidine breakdown and decreases in correspondence to K-hollandite crystallization (Schmidt and Poli 1998, Wang and Takahashi, 1999). In contrast, the $\mathrm{K}_{2} \mathrm{O}$ content in garnet does not increase until pressures above $22.5 \mathrm{GPa}$. A useful barometer is given 


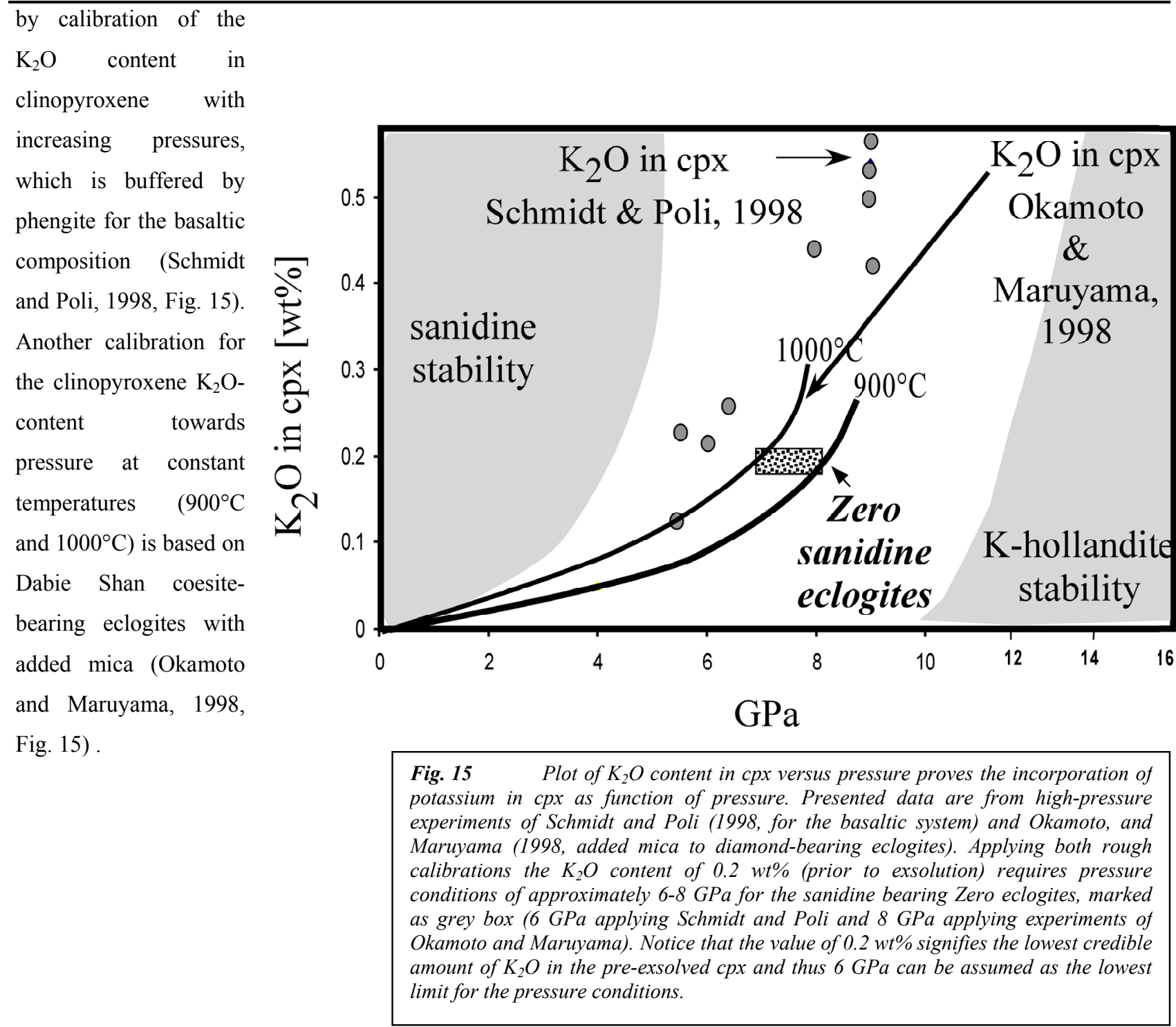

\subsection{Zero eclogite suite was carried to greater depths}

For the purpose of comprehending derivation depth, the $\mathrm{K}_{2} \mathrm{O}$-content of Zero sanidine eclogites was re-constructed with the assistance of phase maps performed by EPMA. In order to eliminate alteration sanidine was discriminated from different $\mathrm{K}_{2} \mathrm{O}$ phases including secondary phlogopite. Based on approximately $1 \mathrm{wt} \%$ granular and lamellar sanidine for the whole rock composition $0.2 \mathrm{wt} \% \mathrm{~K}_{2} \mathrm{O}$ content was estimated. Provided that a part of $\mathrm{K}_{2} \mathrm{O}$ has already been changed to phlogopite the value signifies the lowest credible amount of $\mathrm{K}_{2} \mathrm{O}$ for the precursor. Nevertheless, the protolith of the sanidine bearing eclogites might have been much higher in $\mathrm{K}_{2} \mathrm{O}$ content before dehydration. Using the barometer the $\mathrm{K}_{2} \mathrm{O}$ content of $0.2 \mathrm{wt} \%$ requires a minimum depth equivalent to $6-8 \mathrm{GPa}$, illustrated as the black field in Fig. 15. Due to these findings, the Zero eclogites must have been carried to depths of 180-240 km, and might be in conflict with the assumption that K-rich melts or fluids are connected with diamond formation.

Irrespective of the exact location and genesis of the protoliths, the eclogitic precursor must have been brought to greater depth prior to exhumation and thus might have been subducted. Fig. 16 shows the P-T-t-path for the Zero eclogites and how eclogites might have been formed. Due to the unknown source the crystallization depth within the sub-crustal 
lithosphere (Stage I) is still not defined closely, whereas stage II was reconstructed with $\mathrm{K}_{2} \mathrm{O}$ content in clinopyroxene and stage III has been calculated with thermobarometry. The starting point is a protolith probably consisting mainly of Al-rich clinopyroxene and phlogopite, which was brought to depths of 6-8 GPa (stage II). During the subduction, phlogopite broke down and garnet was produced from phlogopite. It can be assumed that the fluid released from the dehydration probably contained dissolved $\mathrm{Si}^{4+}$ and $\mathrm{K}^{+}$expelled from phlogopite, and was partly trapped in the newly formed garnets as fluid inclusions. These primary garnets formed in stage II are preserved within the layered garnet domains (Fig. 5), which occur in euhedral crystals with abundant inclusions. Since this occurred at about $8 \mathrm{GPa}$, the incorporation of $\mathrm{K}_{2} \mathrm{O}$ into the clinopyroxene structure was possible and homogeneous K-bearing clinopyroxene coexisted with primary garnet. Stage III is indicated by the re-equilibration reactions; garnet, orthopyroxene and sanidine exsolved from clinopyroxene due to decreasing $\mathrm{T}$ and $\mathrm{P}$ around $950^{\circ} \mathrm{C}$ and $3.5 \mathrm{GPa}$. That reequilibration took place during a long time period probably at high temperatures is evidenced by the lack of diffusion gradients in eclogites (Sautter and Harte, 1988). Since sufficient time passed for diffusional reequilibration, a rapid event like the kimberlite eruption can, on no account, be responsible for the exsolution processes.

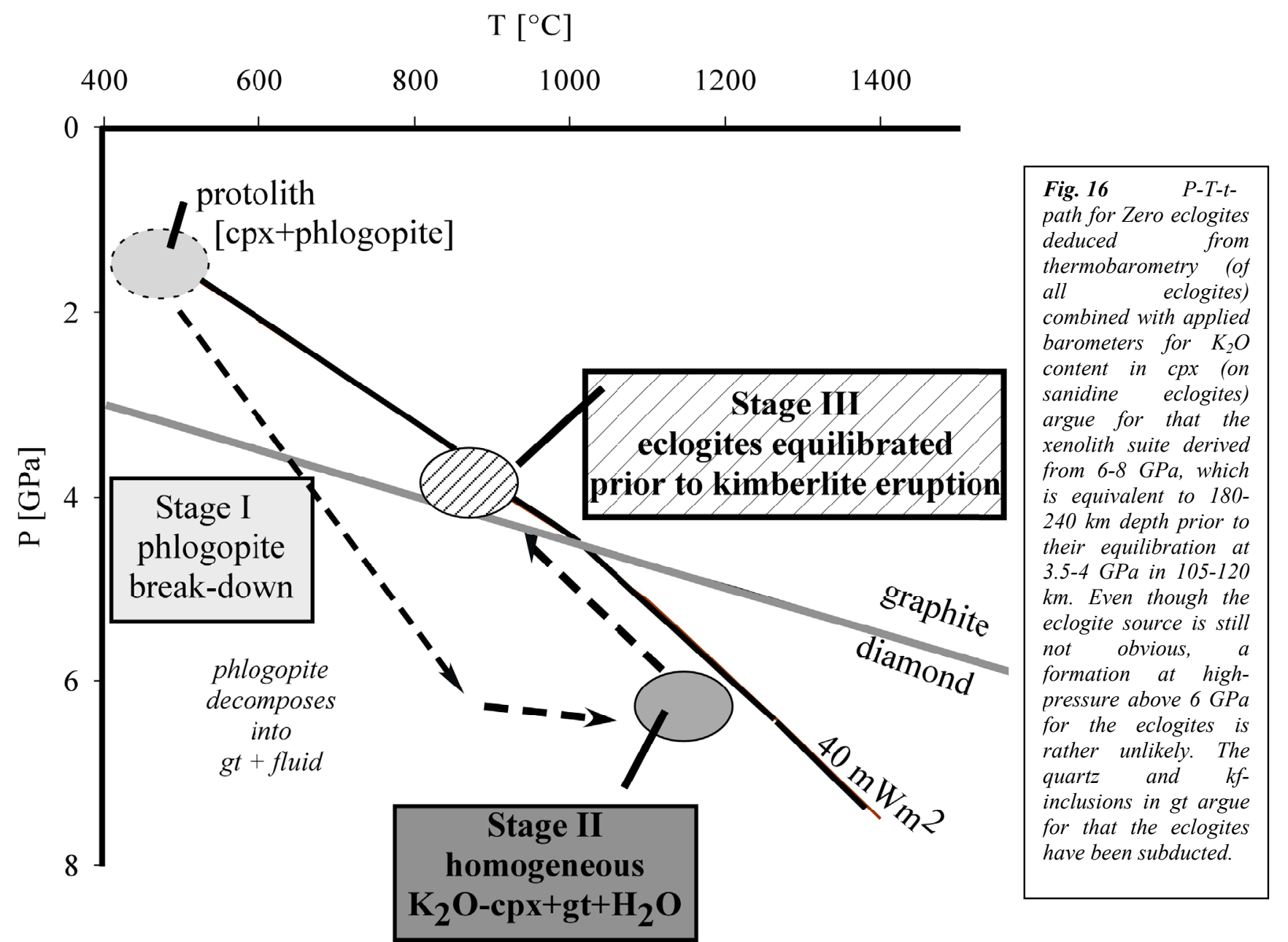

The former $\mathrm{K}_{2} \mathrm{O}$ solubility in clinopyroxene indicate the high pressure conditions (Okamoto and Maruyama, 1998; Schmidt, 1996) and are thus the key to the interpretation given here. Nevertheless, it might be possible that the latter model can be applied only to the sanidine eclogites and might not approach the source for the remaining eclogites. However, considering that orthopyroxene bearing eclogites occur with similar garnet fabrics and inclusions argue for a similar origin at least for these samples, which might have lost almost all $\mathrm{K}_{2} \mathrm{O}$ during dehydration. However whether the Zero eclogites 
are genetically linked is not constrained temporarily, but is likely since a.) they were sampled together, b.) they show similar trends in mineral and rock compositions, and c.) all of them show the same exsolution textures and similar reequilibration temperatures.

Since the Zero suite bears some affinities to pyroxenites, caused by the predominance of cpx, this might argue for their origin as cumulate sequence. They consisted of basal $\mathrm{MgO}$ rich cumulates and plagioclase rich cumulates at the top of the sequence, which might be a feasible explanation for the associated occurrence of orthopyroxene and bimineralic eclogites and the kyanite eclogite. The latter observation confirms the similarity between eclogites and pyroxenites which have been linked to basaltic magmas passing through the mantle (Frey and Green, 1974). Possibly all cumulates were metasomatized to different extents, although mineralogical changes as consequence of intensive metasomatism are observed only at the $\mathrm{MgO}$ rich base of the cumulate sequence, where sanidine-bearing eclogites might have formed. Whether the loss of partial melts may have changed the chemistry of the bimineralic and, in particular the kyanite eclogites, remains to be demonstrated.

\section{References}

Akaogi, M., Yusa, H., K.Shiraishi and Suzuki, T., 1995. Thermodynamic properties of a quartz, coesite, and stishovite and equillibrium phase relations at high pressures and high temperatures. Journal of Geophysical Research, 100(B11): 22,337-22,347.

Alt, J.C., Muehlenbachs, K. and Honnorez, J., 1986. An oxygen isotopic profile through the upper kilometer of the oceanic crust, DSDP Hole 504B. Earth Planet. Sci. Lett., 80: 217-229.

Alt, J. C. 1995. Subseafloor processes in Mid-ocean ridge hydrothermal systems. Seafloor hydrothermal systems: physical, chemical, biological and geological interactions. S. E. Humphris, R. A. Zierenberg, L. S. Mullineaux and R. E. Thomson. Washington, AGU: 85-114.

Aoki, K. and Shiba, I., 1973. Pyroxenes from lherzolite inclusions of Itinomegata, Japan. Lithos, 6: 41-51.

Barth, M., Rudnick, R.L., Horn, I., McDonough, W.F., Spicuzza, M., Valley, J.W. and Haggerty, S.E., 2001. Geochemistry of xenolithic eclogites from West Africa, part I: A link between low MgO eclogites and Archean crust formation. Geochim. Cosmochim. Acta, 65: 1499-1527.

Beard, B.L., Fraracci, K.N., Taylor, L.A., Snyder, G.A., Clayton, R.N., Mayeda, T.K. and Sobolev, N.V., 1996. Petrography and geochemistry of eclogites from the Mir kimberlite, Yakutia, Russia. Contrib. Mineral. Petrol., 125: 293-310.

Bobrievich, A.P., Smirnov, G.I. and V.S.Sobolev, 1960. On the mineralogy of xenoliths of the grossular-pyroxene-disthene rock (grospydite) from kimberlites of Yakutia (in Russian). Geol. i. Geophysika, 3: 18-24.

Boyd, F. and Gurney, J., 1986. Diamonds and the African lithosphere. Science, 272: 472-477.

Brey, G.P. and Köhler, T., 1990. Geothermobarometry in four-phase lherzolites. II. New thermobarometers and practical assessment of existing thermobarometers. Journal of Petrology, 31: 1353-1378.

Brey, G.P., Köhler, T. and Nickel, N.G., 1990. Geothermobarometry in four-phase lherzolites I. Experimental results from 10 to $60 \mathrm{~kb}$. Journal of Petrology, 31: 1353-1378.

Brey, G.P., Nickel, K.G. and Kogarko, L., 1986. Garnet-pyroxene equilibria in the system $\mathrm{CaO}-\mathrm{MgO}-\mathrm{Al}_{2} \mathrm{O}_{3}-\mathrm{SiO}_{2}(\mathrm{CMAS})$ : prospects for simplified ( $\mathrm{T}$-independent) lherzolite barometry and an eclogite-barometer. Contributions to Mineralogy and Petrology, 92: 448-455.

Clayton, R.N., Goldsmith, J.R., Karel, V.J., Mayeda, T.K. and Newton, R.C., 1975. Limits on the effect of pressure on isotopic fractionation. Geochim. Cosmochim. Acta, 39: 1197-1201.

Coleman, R.G., Lee, D.E., Beatty, L.B. and Brannock, W.W., 1965. Eclogites and eclogites: their differences and similarities. Geol. Soc. Am. Bull., 76: 483-508.

Dean, K.J., Sherman, W.F. and Wilkinson, G.R., 1982. Temperature and pressure dependence of the Raman active modes of vibration of a-quartz. Spectrochimica Acta, 38A: 1105-1108.

Ellis, D.J. and Green, D.H., 1979a. An experimental study of the effect of Ca upon garnet-clinopyroxene Fe-Mg exchange equilibria. Contrib. Mineral. Petrol., 71: 13-22.

Fadili, S.E. and Demaiffe, D., 1999. Petrology of eclogite and granulite nodules from the Mbuji Mayi kimberlites (Kasai, Congo): Significance of kyanite-omphacite intergrowth. Proceedings of the 7th kimberlite conference: 205-213.

Falloon, T. and Green, D., 1988. Anhydrous partial melting of peridotite from 8 to $35 \mathrm{~kb}$ and the petrogenesis of MORB. J. Petrol., Special Lithospheric Issue: 379-414.

Frey, F.A. and Green, D.H., 1974. The mineralogy, geochemistry and origin of lherzolite inclusions in Victorian basanites. Geochim. Cosmochim. Acta, 38: 1023-1059.

Fujii, T. and Takahashi, E., 1976. On the solubility of alumina in orthopyroxene coexisting with olivine and spinel in the system MgO-A12O3-SiO3. Min. J. Japan, 8: 149-156. 
Fung, A. and Haggerty, S., 1995. Petrography and mineral compositions of eclogites from the Koidu Kimberlite Komplex, Sierra Leone. Journal Geophys. Res., 100: 20451-20473.

Garlick, G.D., MacGregor, I.D. and Vogel, D.E., 1971. Oxygen isotope ratios in eclogites from kimberlites. Science, 172: 1025-1027.

Green, D.H. and Falloon, T.J., 1998. Pyrolite: A Ringwood concept and its current expression. In: I. Jackson (Editor), The Earth's mantle. Cambridge University Press, Melbourne, pp. 311-380.

Green, D.H. and Ringwood, A.E., 1967a. An experimental investigation of the gabbro to eclogite transformation and its petrological applications. Geochemica Cosmochemica Acta, 31: 767-833.

Green, D.H. and Ringwood, A.E., 1967b. The genesis of basaltic magmas. Contrib. Mineral. Petrol., 15: 103-190.

Gregory, R.T. and Taylor, H.P., 1986. Possible non-equilibrium ${ }^{18} \mathrm{O} /{ }^{16} \mathrm{O}$ effects in mantle nodules, an alternative to the Kyser-O'Neal-Carmichel ${ }^{18} \mathrm{O} /{ }^{16} \mathrm{O}$ geothermometer. Contrib.Mineral. Petrol., 93: 124-135.

Harlow, G.E., 1997. Potassium in clinopyroxene at high pressure and temperature: An experimental study. American Mineralogist, 82: 259-269.

Harlow, G.E., 1999. Interpretation of Kcpx and CaEs in clinopyroxene from diamond inclusions and mantle samples. Proceedings of the seventh International Kimberlite Conference.

Harte, B. and Gurney, J.J.G., 1975. Evolution of clinopyroxene and garnet in an eclogite nodule from the Roberts Victor kimberlite pipe, South Africa. Phys. Chem. Earth, 9: 367-387.

Harte, B. and Kirkley, M.B., 1997. Partitioning of trace elements between clinopyroxene and garnet: data from mantle eclogites. Chem. Geology, 136: 1-24.

Hatton, C.J., 1978. The geochemistry and origin of xenoliths from the Roberts Victor mine. Ph.D. Thesis, University of Cape Town.

Hatton, C.J. and Gurney, J.J., 1987. Roberts Victor eclogites and their relation to the mantle. in: Nixon, P.H. (ed) Mantle Xenoliths;. 453-463.

Helmstaedt, H. and Doig, R., 1975. Eclogite nodules from the Colorado plateau - samples of subducted Franciscan type oceanic lithosphere. Phys. Chem. Earth, 9: 95-111.

Herzberg C. (1978) Pyroxene geothermometry and geobarometry: Experimental and thermodynamic evaluation of some subsolidus phase relations involving pyroxenes in the system $\mathrm{CaO}-\mathrm{MgO}-\mathrm{Al} 203-\mathrm{SiO} 2$. Geochim. Cosmochim. Acta 42, 945-957.

Irvine, T., 1970. The ultramafic rocks of the Muskox intrusions, Northwest Territories, Canada. in Wyllie: Ultramafic and related rocks: $38-45$.

Jackson, E., Green, H. and Moores, E., 1975. The Vourinos ophiolite, Greece: Cyclic units of lineated cumulates overlying harzburgite tectonite:. Geol. Soc. Am. Bull., 86: 390-398.

Jacob, D., Jagoutz, E., Lowry, E., Matthey, D. and Kudrajavtseva, G., 1994. Diamondiferous eclogites from Siberia: remnants of Archean oceanic crust. Geochimica et Cosmochimica Acta, 58: 5191-5207.

Jacob, D.E. and Foley, S.F., 1999. Evidence for Archean oceanic crust with low high field strength element signature from diamondiferous eclogite xenoliths. Lithos, 48: 317-336.

Jagoutz, E., Dawson, J.B., Hoernes, S., Spettel, B. and Wänke, H., 1984. Anorthositic oceanic crust in the Archean Earth. 15th Lunar Planet. Sci. Conf.: 395-396. (abs).

Kiviets, G.B., Phillips, D., Shee, S.R., Vercoe, S.C., Barton, E.S., Smith, C.B. and Fourie, L.F., $1998 .{ }^{40} \mathrm{Ar} /{ }^{39} \mathrm{Ar}$ dating of yimengite from the Turkey Well kimberlite, Australia: the oldest and the rarest. 7th International Kimberlite Conf., Ext. Abstract: 432-433.

Klemme, S., O'Neal H. S. C., Schnelle W., and Gmelin E. (2000) The heat capacity of $\mathrm{MgCr}_{2} \mathrm{O}_{4}, \mathrm{FeCr}_{2} \mathrm{O}_{4}$ and $\mathrm{Cr}_{2} \mathrm{O}_{3}$ at low temperatures and derived thermodynamic properties. Am. Mineralogist: 85, 1686-1693.

Krogh, E., 1988. "The Garnet-Clinopyroxene FeMg geothermometer; a reinterpretation of existing experimental data." Contrib. Mineral. Petrol. 99: 44-48.

Lappin, M.A., (1974). "Eclogites from the Sundal-Grubse Ultra-mafic Mass, Almklovdalen, Norway and the T-P History of the Almklovdalen Masses.” J. Petrol. 15(3): 567-601.

Lappin, M.A., 1978. The evolution of a Grospydite From the Roberts Victor Mine, South Africa. Contrib. Mineral. Petrology, 66: 229-241.

Lappin, M. and D. Smith, 1977. "Mantle equilibrated Orthopyroxene Eclogite Pods from the Basal Gneisses in the Selje District, Western Norway." J. Petrol. 19(3): 530-584.

MacGregor, I.D. and Carter, J.L., 1970. The chemistry of clinopyroxenes and garnets of eclogite and peridotite xenoliths from the Roberts Victor mine, South Africa. Phys. Earth Planet. Int., 3: 391-397.

MacGregor, I.D. and Manton, W.I., 1986. Roberts Victor eclogites: ancient oceanic crust. J. Geophys. Res., 91(B14): 1406314079 .

Mattey, D.P., Lowry, D., MacPherson, C.G. and Chazot, G., 1994. Oxygen isotope composition of mantle minerals by laser fluorination analysis: homogeneity in peridotites, heterogeneity in eclogites. Min. Mag., 58A: 573-574.

Mattey, D.P., Lowry, D. and Macpherson, C., 1994. Oxygen isotope composition of mantle peridotite. Earth and Planetary Science Letters, 128: 231-241.

McCandless, T.E. and Gurney, J.J., 1986. Sodium in garnet and potassium in clinopyroxene: Criteria for classifying mantle eclogites. Univ. Cape town Kimb. Res. Group, Int. Rept.(10): 60p.

McCulloch, M. T., R. T. Gregory, et al., 1981. "Sm-Nd, Rb-Sr and 18O/16O isotopic systematics in an oceanic crustal section: evidence from the Samail ophiolite." J. Geophys. Res. 86: 2721-2735. 
Mitchell, R., 1984. Mineralogy and origin of carbonate-rich segregations in a composite kimberlite sill. N Jb Miner Abh, 150: $185-197$.

Mosenfelder, J.L., 1997. Kinetics of the coesite to quartz transformation. Earth and Planetary Science Lett., 153.

Muehlenbachs, K., 1986. Alteration of the oceanic crust and the ${ }^{18} \mathrm{O}$ history of seawater. Reviews in Mineralogy. J. W. Valley, H. P. Taylor and J. R. O'Neill. Washington D.C., Mineral. Soc. America. 16: 425-444.

Neal, C., L. Taylor, et al., 1990. "Eclogites with oceanic crustal and mantle signatures from the Nellsbank kimberlite, South Africa part 2: Sr, Nd and O isotope geochemistry." Earth Planet. Sci. Lett. 99: 362-379.

Nickel, K.G. and Green, D.H., 1985. Experimental geothermobarometry for garnet peridotites and implications for the nature of the lithosphere, kimberlites and diamonds. Earth planet Sci. Lett., 73: 158-70.

O`Hara, M.J. and Yoder, H.S., 1967. Formation and fractionation of basic magmas at high pressures. Scott. J. Geol., 3: 67117.

Okamoto, K. and Maruyama, S., 1998. Multi-anvil re-equilibration experiments of a Dabie Shan ultrahigh-pressure eclogite within the diamond-stability fields. The Island Arc, 7: 52-69.

Pollack, H. and Chapman, D., 1977. On the regional variation of heat flow, geotherms, and lithospheric thickness. Tectonophysics, 38: 279-296.

Rapp, R.P. and Watson, E.B., 1995. Dehydration melting of metabasalt at 8-32 kbar: implications for continental growth and crust-mantle recycling. J. Petrol., 36: 891-931.

Ringwood, A. and Green, D., 1966. An experimental investigation of the gabbro-eclogite transformation and some geophysical implications. Tectonophysics, 3: 383-427.

Rosenbaum J. M., Walker D., and Kyser K. (1994) Oxygen isotope fractionation in the mantle. Geochimica et Cosmochimica acta 58(21), 4767-4777.

Rossman G., 1988. Vibrational Spectroscopy of hydrous components in: Rev. in Mineralogy 18: Spectroscopic Methods in Mineralogy and Geology: 195-206.

Sautter, V. and Harte, B., 1988. Diffusion gradients in an Eclogite Xenolith from the Roberts Victor Kimberlite Pipe: 1. Mechanism and evolution of Garnet Exsolution in $\mathrm{Al}_{2} \mathrm{O}_{3}$-rich Clinopyroxene. Journal of Petrology, 29: 1325-1352.

Schmidt, C. and Ziemann M, A., 2000. "In-situ Raman spectroscopy of quartz: A pressure sensor for the hydrothermal diamond anvil cell experiments at elevated temperatures." American Mineralogist 85: 1725-1734.

Schmidt, M. W., 1996. Experimental constraints on recycling of potassium from subducted oceanic crust. Science, 272: 1927-1930.

Schmidt, M.W. and Poli, S., 1998. Experimentally based water budgets for dehydrating slabs and consequences for arc magma generation. Earth and Planetary Science Letters, 124: 105-118.

Schulze, D.J., 1989. Constraints on the abundance of eclogite in the upper mantle. J. Geophysical Res., 94: 4205-4212.

Schulze D. J., Valley J. W., and Spicuzza M., 2000. Coesite eclogites from the Roberts Victor kimberlite, South Africa. Lithos 54, 23-32. Shee, S.R., Bristow, J.W., Bell, D.R., Smith, C.B., Allsopp, H.L. and Shee, P.B., 1986. The petrology of kimberlites, related rocks and associated mantle xenoliths from the Kuruman province, South Africa. Proceedings of the Fourth International Kimberlite Conference, Perth 1986: 60-82.

Shervais, J.W., Taylor, L.A., Lugmair, G.W., Clayton, R.N., Mayeda, T.K. and Korotev, R., 1988. Archean oceanic crust and the evolution of sub-continental mantle: eclogites from Southern Africa. Geol. Soc. Amer. Bull., 100: 411-423.

Smith, C.B., Gurney, J.J., Harris, J.W., Robinson, D.N., Shee, S.R. and Jagoutz, E., 1989. Sr and Nd isotopic systematics of diamond-bearing eclogitic xenoliths and eclogite inclusions in diamond from southern Africa. In: J. Ross et al. (Editors), Kimberlites and related rocks. GSA Special Publication No. 14, Perth, pp. 853-863.

Smyth, J.R. and Caporuscio, F.A., 1984. Petrology of a suite of eclogite inclusions from the Bobbejaan kimberlite: II. Primary phase compositions and origin. In: J. Kornprobst (Editor), Kimberlites II: The Mantle and Crust-Mantle Relationships. Elsevier, New York, pp. 121-132.

Smyth, J.R., Caporuscio, F.A. and McCormick, T.C., 1989a. Mantle eclogites: evidence of igneous fractionation in the mantle. Earth Planet. Sci. Lett., 93: 133-141.

Sobolev and Shatsky, V.S., 1990. Diamond inclusions in garnets from metamorphic rocks. Nature, 343: $742-746$.

Stachel, T., Harris, J.W., Brey, G.P. and Joswig, W., 2000. Kankan diamonds (Guinea) II: lower mantle inclusion parageneses. Contrib. Mineral. Petrol, 140: 16-27.

Takahashi, E., 1986. Melting of a dry peridotite KLB-1 up to $14 \mathrm{GPa}$ : Implication on the origin of peridotite upper mantle. Journal of Geophysical Research, 91(B9): 9367-9382.

Taylor, L.A. and Neal, C.R 1989. Eclogites with oceanic crustal and mantle signatures from the Bellsbank kimberlite, South Africa, partI: Mineralogy, petrography and whole rock chemistry. J.Geol. 97(5), 551-567.

Taylor, W.R., 1998. An experimental test of some geothermometers and geobarometer formulations for upper mantle peridotites with application to the thermobarometry of fertile lherzolite and garnet websterite. Neues Jahrbuch für Mineralogie, Abhandlungen, 172: 381-408.

Wang, W. and Takahashi, E., 1999. Subsolidus and melting experiments of a K-rich basaltic composition to 27 GPa: Implication for the behavior of potassium in the mantle. American Mineralogist, 84: 357-361.

Yaxley, G.M. and Green, D.H., 1998. Reactions between eclogite and peridotite: mantle refertilisation by subduction of oceanic crust. Schweiz.Mineral.Petrogr. Mitt., 78: 243-255.

Zack, T., 2000. Trace element mineral analysis in high pressure metamorphic rocks from Trescolmen, Central Alps. Contribution of Min. Pet.(Göttingen, Univ.,Diss). 


\title{
II. The source of the Zero eclogite xenoliths inferred from trace elements
}

\begin{abstract}
The eclogite suite from the $\sim 1.6$ Ga Zero kimberlite is mineralogically unusually diverse, bears evidence for multiple P-T-tstages and is characterized by mantle-like oxygen isotopic compositions. In-situ trace element analyses of minerals show that sanidine bearing, orthopyroxene bearing, bimineralic and kyanite eclogites, have REE abundances close to, or even more depleted than, primitive mantle, demonstrating that they originated from a fractionated igneous source. Most eclogites show enrichment in LREE to different extents caused by a metasomatic imprint at a late stage. The kyanite eclogite and one bimineralic eclogite occur with slight positive Eu-anomalies, whereas in the remaining eclogites no indication of plagioclase in the protolith is present. High $\mathrm{Ni}$ and $\mathrm{Cr}$ contents of some orthopyroxene bearing eclogites indicative that olivine and chromium-spinel were present in the protolith. Low trace element abundance including low $\mathrm{Nb}, \mathrm{Ta}, \mathrm{Zr}$ and $\mathrm{Hf}$ appears to be characteristic for the eclogite suite. According to trace element modeling combined with modeled crystal accumulation from potential parental magmas we can show that the protolith of the eclogites were generated by igneous fractionation from picritic magma generated at $1.8 \mathrm{GPa}$. The best model for the Zero eclogites resulted from crystallization of the picrite at 11.5 GPa, indicating development of the eclogite protolith in the upper mantle, suggesting a formation within the subcontinental lithosphere. That the resulted cumulate consisted of spinel and clinopyroxene in the presence of plagioclase has significant implications for the genesis of the Zero eclogite. Although the presence of plagioclase in the protolith is not indicated in the trace element pattern by Eu- anomalies in most Zero eclogites, the modeled trace element patterns show that small amounts of plagioclase were present in the protolith, but in insufficient amounts to lead to noticeable positive Eu anomalies. The requirement for plagioclase is in contrast to the hypothesis for crystallization at mantle pressures. The metamorphic history of the Zero eclogites can be used to constrain geodynamic processes at the western margin of the Kaapvaal craton during the early Proterozoic. The eclogitic protoliths were formed at about 30-45 km, and then were brought to depths of at least 180-240 km (6-8 GPa), witnessing that sub-continental lithosphere was displaced at least 150 $\mathrm{km}$ deeper into the mantle. Construction of the P-T-t-path draws largely on sanidine bearing eclogites, which originated from metasomatic veins consisting of phlogopite and clinopyroxene pervading cumulates prior to metamorphism. The eclogitization of the metasomatised protolith was caused by the collision of the Kheis terrane ( $2 \mathrm{Ga}$ ) with the Kaapvaal craton $(2.7 \mathrm{Ga})$ at the western margin of the craton. As the eclogite protolith was metasomatised prior to the eclogitization, it is likely that the protolith formed in a magma chamber situated underneath the Kheis belt which was later underplated prior to the collision with the Kaapvaal craton. Hence, the geological situation argues that the Zero eclogites should not be notably older than the Kheis belt, which is about $2 \mathrm{Ga}$.
\end{abstract}

\section{Introduction}

However, apart from the $\delta^{18} \mathrm{O}$ values for unchanged Earth mantle some facts about the Zero eclogites including the mafic compositions and relatively low jadeite contents compared to different eclogite xenolith suites might argue for the direct mantle derivation. The plutonic igneous crystallization at high temperature followed by sub-solidus exsolution is 
further supported by the exsolution textures which are shared feature of all eclogite types and occurred in response to changing $\mathrm{P} / \mathrm{T}$ conditions caused by the unmixing of clinopyroxene and $\mathrm{Al}_{2} \mathrm{O}_{3}$ at lower temperatures (Frey, 1980).

Thus, the associated exsolution of orthopyroxene and garnet from cpx could indicate high temperature processes but might just result from adiabatic ascent of the eclogites. However, a complex mantle history was inferred for the Zero eclogites on the basis of thermobarometry of all eclogite xenoliths combined with a pressure estimation on the sanidine eclogites in which sanidine exsolutions from clinopyroxene prove the preceding existence of high- $\mathrm{K}_{2} \mathrm{O}$ clinopyroxenes. According to this, the eclogites derived previously from pressure conditions of 6-8 GPa equivalent to $180-240 \mathrm{~km}$ before they equilibrated for a relevant time at $950^{\circ} \mathrm{C} / 3.5-4.0 \mathrm{GPa}$ on average hence in $105-120 \mathrm{~km}$ depth prior to the kimberlite eruption. These findings indicate equilibration under lithospheric conditions for the eclogites although the high-pressure mantle origin contradict to the occurrence of quartz, clinopyroxene, rutile and K-feldspar inclusions in garnets of the eclogites, which may not represent primary mantle phases. In order to assess possible models for the source of the multistage evolution of "mantle eclogites" from the Zero kimberlite we focused on the trace element abundance of the wellpreserved xenoliths.

Though trace elements partitioning behavior is still discussed and described as caused by thermodynamics (Gaetani and Grove, 1995) and as function of size of the substituting ion controlled by the crystal chemistry, the optimum size of the site and the rigidity of the crystal lattice (Wood and Blundy, 1997) trace elements are essential for modeling primarily igneous processes. However, since several trace elements may be important markers for evaluating subduction related dehydration, metamorphism and partial melting as well as metasomatic or hydrothermal events the partitioning of trace elements between coexisting phases appear as well as useful fingerprint to reconstruct the genesis of metamorphic rocks. However, since the eclogites passed through various P-T-t-conditions within the mantle, possible processes need to be distinguished from the kimberlite incorporation itself, which might also have changed the mineralogy and the chemical signatures of the eclogites.

The understanding of trace element abundance by application of experimentally determined partition coefficients is, however, complex since trace element partitioning between minerals and melt is primarily controlled by the major element chemistry of the minerals (Beattie, 1994; Blundy and Wood, 1994; Onuma et al., 1968), and bulk rock chemistry, which are in turn related to pressure and temperature. Systematic changes in cpx/gt partitioning for trace elements to be related to changes in major element composition and in particular to changes in $\mathrm{Ca} /(\mathrm{Ca}+\mathrm{Mg})$ or $\mathrm{Ca} /\left(\mathrm{R}^{2+}\right)$ in garnet and clinopyroxene was shown on eclogite xenoliths from Roberts Victor (Harte and Kirkley, 1997). Furthermore, Westrenen et al., (1999) have shown that trace element partitioning varies substantially as function of composition along solid solution series in garnet.

Recent trace element studies on eclogite xenoliths from different kimberlites Udachnaya (Jacob and Foley, 1999), Koidu (Sierra Leone; (Barth, 2001) and Roberts Victor (Jacob et al., 2002) demonstrate that eclogites representing former ocean crust formed as lavas or in a magma chamber, and often represent residues after partial melting during the subduction process. The trace element compositions of different eclogite parageneses of the present study might represent a useful contribution to the debated models of eclogites origin and yield further information for the interpretation of the geological setting situation at the western margin of the Kaapvaal craton.

\subsection{Zero eclogites}

The eclogites studied come from the Zero kimberlite, which occurs as one of the 12 non-diamondiferous kimberlites from the Kuruman province at the western craton margin (Northern Cape Province, South Africa), representing the oldest kimberlites on the Kaapvaal craton (1.6 Ga; Shee et al., 1986). Other than the age, the diversity of eclogite parageneses is a notable feature of the Zero pipe. In addition to the common bimineralic eclogites (clinopyroxene and garnet), rare 
orthopyroxene bearing, and orthopyroxene plus sanidine bearing eclogites and one kyanite eclogite occur. All samples have clinopyroxene as the most abundant mineral and garnet exsolution from clinopyroxene, which might imply a pyroxenitic protolith. In eclogites with orthopyroxene and sanidine, both constituents have been exsolved from clinopyroxene. A more detailed description of the petrography and mineralogy is given in the previous study.

\section{Analytical methods}

Trace element analysis were performed by laser ablation ICP MS at Memorial University of Newfoundland using a frequency quadrupled $266 \mathrm{~nm}$ wavelength Nd:YAG laser, integrated with an enhanced sensitivity Fisons PQII + "S" ICP MS. Operating conditions were optimized by laser pulse energies from 0.5-1.5 mJ of (always at $10 \mathrm{~Hz}$ ). The laser beam was defocused between $100-400 \mu \mathrm{m}$ above the sample to reduce fractionation effects and to reach a regular energy distribution on the mineral surface, which leads to smooth ablation behavior. Ca content analyzed by EPMA was used as internal standard for garnet and clinopyroxene while NIST SRM 610 and 612 glasses doped with abundant trace elements were used as external standards. Detailed information about analytical procedures and settings, laser source and data reduction can be found in Longerich et al. (1996; Horn et al., 1997). The detection limits are highly dependent upon pit diameters, a 2 fold decrease in pit diameter and depth results in almost a 10 fold increase in detection limits. With pit sizes between $40-100 \mu \mathrm{m}$ measurements in regular polished thin sections, detection limits are different for each spot analysis resulting on average of $40 \mathrm{ppb}$ for REE, LILE and HFSE. If mineral inclusions were analyzed accidentally they could easily eliminated from data reduction by inspection of each measurement in time resolved mode.

Caused by the unusual ablation behavior, sanidine properly did not lead to the usual well-defined laser pits, but tends to ablate catastrophically under the laser beam. Hence the trace element analyses of small sanidine exsolutions are plagued by inaccuracies in the time integrated counting signals provoked by contamination of material from grain boundaries or cracks. Therefore, analyses of trace elements in small sanidine exsolutions were performed by secondary ion mass spectrometry (SIMS) at GFZ Potsdam. By using a finely focused primary ion beam (-O) and positive secondary ions a small percentage of the investigated material is ionized and ions are accelerated into a mass spectrometer where they are separated according to their mass-charge ratio. An important characteristic of SIMS is its high sensitivity by a small spot size (data presented in Table 3). The ability to count individual ions results in detection limits in the parts-per-billion range for many elements. The Cameca ims $6 \mathrm{f}$ has a realistic limit of detection for most elements in the range of 1 to $100 \mathrm{ppb}$. Such determinations have a typical spatial resolution of 10 to 20 micrometers. The natural reference material was measured during the same analytical session in order to correct for variations in ion yields, which depend on the chemistry and the structure of the matrix.

\section{Results}

\subsection{Trace element composition of the eclogites}

Trace element compositions of garnet, clinopyroxene, sanidine and orthopyroxene were analyzed with 250 measurements from 2 sanidine eclogites (ZKE1, Z267), 6 orthopyroxene (Z291, Z332, Z341, Z217, Z330, Z469) bearing eclogites, 4 bimineralic samples (Z298, Z257, Z239, Z323) and the kyanite eclogite (Z356). Detection limit-filtered LAM trace element data for cpx and garnet of all Zero eclogite types are given in table 1 and 2, LAM and SIMS data for sanidine are given in table 3 (most orthopyroxene data have been below detection limits and are thus not tabulated). 
Table $1 \quad$ Trace element composition of garnets (in ppm) determined by LA-ICP-MS

\begin{tabular}{|c|c|c|c|c|c|c|c|c|c|c|c|c|c|c|}
\hline garnet & ZKE1 & $\mathrm{Z} 267$ & $\mathrm{Z188}$ & $\mathrm{Z} 217$ & $\overline{Z 291}$ & $\mathrm{Z330}$ & Z332 & $\mathrm{Z341}$ & Z469 & Z298 & Z239 & $\mathrm{Z} 257$ & Z323 & Z356 \\
\hline $\mathbf{n}$ & 32 & 7 & 4 & 4 & 6 & 3 & 7 & 4 & 2 & 3 & 4 & 6 & 5 & 4 \\
\hline$\overline{\mathbf{B a}}$ & 0.219 & 0.027 & 0.018 & 0.014 & 0.014 & 0.008 & 0.047 & 0.798 & 0.361 & 0.105 & 0.008 & 0.008 & 0.006 & 0.031 \\
\hline Th & 0.006 & 0.012 & 0.010 & 0.020 & 0.009 & 0.011 & 0.003 & 0.077 & 0.045 & 0.019 & 0.059 & 0.014 & 0.012 & 0.110 \\
\hline $\mathbf{U}$ & 0.004 & 0.009 & 0.026 & 0.025 & 0.029 & 0.015 & 0.003 & 0.044 & 0.021 & 0.053 & 0.140 & 0.026 & 0.049 & 0.241 \\
\hline Nb & 0.037 & 0.043 & 0.063 & 0.136 & 0.053 & 0.051 & 0.014 & 0.094 & 0.057 & 0.144 & 0.142 & 0.073 & 0.171 & - \\
\hline Ta & 0.000 & 0.002 & 0.001 & 0.001 & 0.002 & 0.000 & 0.001 & 0.002 & 0.001 & 0.005 & 0.003 & 0.001 & 0.001 & 0.000 \\
\hline La & 0.022 & 0.020 & 0.041 & 0.011 & 0.017 & 0.014 & 0.100 & 0.071 & 0.532 & 0.016 & 0.058 & 0.011 & 0.036 & 0.165 \\
\hline $\mathrm{Ce}$ & 0.151 & 0.090 & 0.296 & 0.080 & 0.107 & 0.103 & 0.567 & 0.206 & 1.534 & 0.059 & 0.495 & 0.094 & 0.179 & 0.752 \\
\hline $\mathbf{P b}$ & 0.056 & 0.024 & 0.097 & 0.082 & 0.066 & 0.042 & 0.023 & 0.410 & 0.198 & 0.083 & 0.020 & 0.026 & 0.207 & 0.104 \\
\hline Pr & 0.026 & 0.027 & 0.102 & 0.027 & 0.029 & 0.033 & 0.052 & 0.056 & 0.057 & 0.012 & 0.130 & 0.034 & 0.090 & 0.099 \\
\hline $\mathrm{Sr}$ & 0.250 & 0.137 & 0.119 & 0.069 & 0.074 & 0.058 & 0.024 & 0.343 & 5.735 & 0.071 & 0.180 & 0.094 & 0.131 & 0.473 \\
\hline Nd & 0.254 & 0.322 & 0.707 & 0.435 & 0.216 & 0.311 & 0.042 & 0.353 & 0.327 & 0.137 & 0.891 & 0.368 & 0.674 & 0.175 \\
\hline Sm & 0.183 & 0.282 & 0.367 & 0.687 & 0.253 & 0.326 & 0.167 & 0.400 & 0.256 & 0.116 & 0.287 & 0.353 & 0.206 & 0.087 \\
\hline $\mathbf{Z r}$ & 0.520 & 1.373 & 0.647 & 3.483 & 0.869 & 1.851 & 0.184 & 2.879 & 2.645 & 1.218 & 0.897 & 2.367 & 0.197 & 0.048 \\
\hline Hf & 0.022 & 0.026 & 0.032 & 0.117 & 0.036 & 0.043 & 0.026 & 0.067 & 0.081 & 0.000 & 0.039 & 0.051 & 0.008 & 0.003 \\
\hline $\mathbf{E u}$ & 0.158 & 0.170 & 0.248 & 0.596 & 0.199 & 0.216 & 0.208 & 0.278 & 0.164 & 0.109 & 0.162 & 0.244 & 0.149 & 0.131 \\
\hline $\mathbf{T i}$ & 817 & 1003 & 762 & 2211 & 502 & 924 & 689 & 902 & 1201 & 725 & 444 & 1291 & 471 & 23.211 \\
\hline Gd & 0.619 & 0.814 & 1.035 & 1.957 & 1.051 & 0.806 & 0.849 & 1.356 & 0.651 & 0.389 & 0.613 & 0.864 & 0.342 & 0.205 \\
\hline $\mathbf{T b}$ & 0.193 & 0.231 & 0.312 & 0.537 & 0.302 & 0.189 & 0.253 & 0.356 & 0.176 & 0.093 & 0.132 & 0.193 & 0.079 & 0.067 \\
\hline Dy & 1.873 & 2.302 & 2.729 & 4.043 & 2.725 & 1.507 & 2.441 & 3.094 & 1.538 & 0.801 & 1.134 & 1.404 & 0.619 & 0.685 \\
\hline $\mathbf{Y}$ & 13.26 & 13.73 & 18.57 & 28.43 & 17.39 & 9.65 & 15.95 & 20.71 & 9.98 & 5.02 & 4.03 & 7.73 & 4.54 & 5.50 \\
\hline Ho & 0.52 & 0.60 & 0.75 & 0.97 & 0.67 & 0.35 & 0.59 & 0.73 & 0.36 & 0.20 & 0.28 & 0.34 & 0.16 & 0.24 \\
\hline Er & 1.81 & 2.17 & 2.31 & 2.90 & 2.24 & 1.19 & 1.99 & 2.50 & 1.25 & 0.63 & 0.88 & 1.06 & 0.57 & 0.78 \\
\hline $\mathbf{T m}$ & 0.29 & 0.35 & 0.38 & 0.41 & 0.31 & 0.17 & 0.28 & 0.35 & 0.17 & 0.09 & 0.15 & 0.16 & 0.09 & 0.12 \\
\hline $\mathbf{Y b}$ & 1.97 & 2.55 & 2.86 & 2.70 & 2.10 & 1.17 & 2.01 & 2.39 & 1.26 & 0.50 & 0.99 & 1.09 & 0.76 & 0.93 \\
\hline Lu & 0.34 & 0.41 & 0.44 & 0.38 & 0.34 & 0.18 & 0.33 & 0.35 & 0.19 & 0.09 & 0.15 & 0.18 & 0.14 & 0.13 \\
\hline Sc & 258 & 64 & 88 & 93 & 105 & - & 136 & 378 & 155 & 96 & - & - & 84 & 164 \\
\hline $\mathbf{V}$ & 90 & 87 & 75 & 196 & 74 & 206 & 229 & 64 & 68 & 63 & 43 & 99 & 57 & 28 \\
\hline $\mathrm{Cr}$ & 1344 & 1402 & 1473 & 5681 & 1355 & 7373 & 726 & 1244 & 1000 & 612 & 2347 & 1260 & 1573 & 511 \\
\hline Mn & 7316 & 5832 & 9731 & 6430 & 9031 & 5759 & 8086 & 8749 & 4754 & 4955 & 4708 & 3583 & 5036 & 6910 \\
\hline Co & 75 & 74 & 68 & 66 & 57 & 77 & 69 & 59 & 49 & 69 & 66 & 58 & 50 & 55 \\
\hline $\mathrm{Ni}$ & 22 & 41 & 348 & 25 & 26 & 43 & - & 28 & 79 & 29 & 26 & 44 & 22 & 45 \\
\hline XGrs & 0.090 & 0.083 & 0.082 & 0.10 & 0.10 & 0.10 & 0.08 & 0.08 & 0.08 & 0.09 & 0.09 & 0.10 & 0.30 & 0.509 \\
\hline
\end{tabular}

Table 2 Trace element composition of cpx (in ppm) determined by LA-ICP-MS

\begin{tabular}{|c|c|c|c|c|c|c|c|c|c|c|c|c|c|c|}
\hline cpx & ZKE1 & Z267 & $\mathrm{Z188}$ & $\mathrm{Z} 217$ & Z291 & $\overline{Z 330}$ & $\mathrm{Z332}$ & Z341 & Z469 & Z298 & Z239 & Z257 & Z323 & Z356 \\
\hline $\mathbf{n}$ & 25 & 7 & 6 & 2 & 2 & 2 & 12 & 3 & 2 & 5 & 7 & 7 & 2 & 5 \\
\hline Cs & 0.008 & - & - & - & 0.004 & - & 0.001 & 0.036 & 0.000 & 0.000 & 0.001 & 0.002 & 0.065 & - \\
\hline $\mathbf{R b}$ & 0.306 & 0.039 & 0.279 & - & 0.094 & - & & - & 0.045 & - & - & 0.154 & & 0.017 \\
\hline $\mathbf{B a}$ & 0.237 & 0.274 & 0.230 & - & 0.397 & 0.075 & 0.181 & 0.224 & 0.192 & 0.393 & 0.341 & 0.136 & & 1.180 \\
\hline Th & 0.085 & 0.293 & 0.354 & 0.417 & 0.500 & 0.004 & 0.091 & 1.028 & 0.189 & 1.195 & 2.793 & 0.970 & 0.352 & 0.501 \\
\hline $\mathbf{U}$ & 0.005 & 0.027 & 0.060 & 0.041 & 0.050 & 0.009 & 0.004 & 0.103 & 0.070 & 0.153 & 0.420 & 0.123 & 0.133 & 0.087 \\
\hline Nb & 0.025 & 0.316 & 0.341 & 0.284 & 0.042 & - & 0.101 & 0.431 & 0.021 & 2.703 & 1.436 & 0.810 & 0.797 & 0.257 \\
\hline Ta & 0.007 & 0.014 & 0.010 & 0.007 & 0.001 & - & - & 0.030 & - & 0.087 & 0.114 & 0.057 & 0.080 & - \\
\hline La & 3.19 & 4.43 & 9.24 & 4.86 & 5.21 & 0.02 & 0.58 & 11.70 & 1.29 & 17.95 & 34.25 & 8.00 & 2.20 & 2.21 \\
\hline $\mathrm{Ce}$ & 10.25 & 12.30 & 31.56 & 12.08 & 4.82 & 0.49 & 0.59 & 26.36 & 13.74 & 39.88 & 84.59 & 19.04 & 5.31 & 3.08 \\
\hline $\mathbf{P b}$ & 0.43 & 0.75 & 0.68 & 0.79 & 1.40 & 0.33 & 0.20 & 1.33 & 0.44 & 1.10 & 2.13 & 1.59 & 0.92 & 0.42 \\
\hline Pr & 1.19 & 1.42 & 3.52 & 1.44 & 0.34 & 0.00 & 0.06 & 2.60 & 0.40 & 3.16 & 7.33 & 2.19 & 0.49 & 0.18 \\
\hline $\mathrm{Sr}$ & 132 & 129 & 180 & 62 & 72 & - & 20 & 186 & 73 & 213 & 297 & 183 & 60 & 77 \\
\hline Nd & 3.71 & 4.92 & 11.55 & 5.94 & 1.29 & - & 0.56 & 8.14 & 2.39 & 8.83 & 15.54 & 8.37 & 1.12 & 0.30 \\
\hline Sm & 0.49 & 0.75 & 1.29 & 1.45 & 0.51 & 0.02 & 0.42 & 1.21 & 0.55 & 0.90 & 1.19 & 1.31 & 0.14 & 0.07 \\
\hline $\mathbf{Z r}$ & 1.38 & 2.94 & 2.54 & 4.00 & 0.99 & & 0.53 & 9.59 & 4.47 & 1.56 & 1.33 & 4.62 & 0.65 & \\
\hline Hf & 0.08 & 0.26 & 0.25 & 0.19 & 0.19 & - & 0.14 & 0.19 & 0.22 & 0.04 & 0.11 & 0.16 & - & 0.00 \\
\hline Eu & 0.19 & 0.28 & 0.36 & 0.57 & 0.22 & 0.03 & 0.23 & 0.44 & 0.21 & 0.26 & 0.24 & 0.40 & 0.06 & 0.01 \\
\hline $\mathrm{Ti}$ & 535 & 1032 & 1401 & 1414 & 540 & 392 & 2429 & 1090 & 1689 & 897 & 408 & 2779 & 577 & 58.08 \\
\hline Gd & 0.498 & 0.701 & 0.835 & 1.273 & 0.432 & 0.034 & 0.555 & 1.064 & 0.344 & 0.447 & 0.460 & 0.695 & 0.080 & 0.022 \\
\hline $\mathbf{T b}$ & 0.069 & 0.093 & 0.099 & 0.109 & 0.056 & - & 0.073 & 0.139 & 0.060 & 0.038 & 0.043 & 0.073 & 0.008 & - \\
\hline Dy & 0.343 & 0.492 & 0.492 & 0.648 & 0.312 & - & 0.416 & 0.625 & 0.252 & 0.141 & 0.144 & 0.232 & 0.033 & 0.027 \\
\hline $\mathbf{Y}$ & 1.217 & 1.481 & 1.690 & 1.650 & 0.824 & 0.054 & 1.339 & 2.144 & 0.771 & 0.529 & 0.342 & 0.632 & 0.313 & 0.034 \\
\hline Ho & 0.049 & 0.073 & 0.071 & 0.061 & 0.039 & 0.000 & 0.058 & 0.063 & 0.037 & 0.016 & 0.025 & 0.028 & 0.007 & 0.001 \\
\hline Er & 0.086 & 0.166 & 0.107 & 0.193 & 0.062 & 0.007 & 0.106 & 0.119 & 0.049 & 0.030 & 0.047 & 0.049 & 0.002 & 0.011 \\
\hline $\mathbf{T m}$ & 0.008 & 0.017 & 0.010 & 0.009 & 0.004 & 0.000 & 0.010 & 0.013 & 0.006 & 0.006 & 0.004 & 0.003 & 0.004 & - \\
\hline $\mathbf{Y b}$ & 0.048 & 0.066 & 0.050 & 0.044 & 0.017 & 0.010 & 0.047 & 0.034 & 0.006 & 0.038 & 0.018 & 0.016 & 0.010 & 0.030 \\
\hline Lu & 0.005 & 0.009 & 0.007 & 0.007 & 0.003 & - & 0.005 & 0.002 & 0.001 & 0.006 & 0.002 & 0.002 & - & 0.001 \\
\hline Sc & 71 & - & 50 & 44 & - & - & - & - & - & - & - & - & 38 & 25 \\
\hline $\mathbf{V}$ & 224 & 238 & 242 & 264 & 241 & 78 & 463 & 201 & 231 & 235 & 164 & 293 & 206 & 53 \\
\hline $\mathrm{Cr}$ & 764 & 1193 & 883 & 1533 & 1953 & 681 & 294 & 383 & 775 & 692 & 1615 & 1107 & 1725 & 452 \\
\hline Mn & 1380 & 1189 & 1802 & 1182 & 854 & 2000 & 1558 & 2076 & 784 & 772 & 706 & 625 & 920 & 236 \\
\hline Co & 38 & 41 & 36 & 41 & 34 & 116 & 47 & 34 & 35 & 35 & 27 & 35 & 26 & 13 \\
\hline $\mathbf{N i}$ & 327 & 495 & 1262 & 393 & 526 & 1633 & 205 & 187 & 625 & 847 & 1823 & 567 & 275 & 309 \\
\hline
\end{tabular}



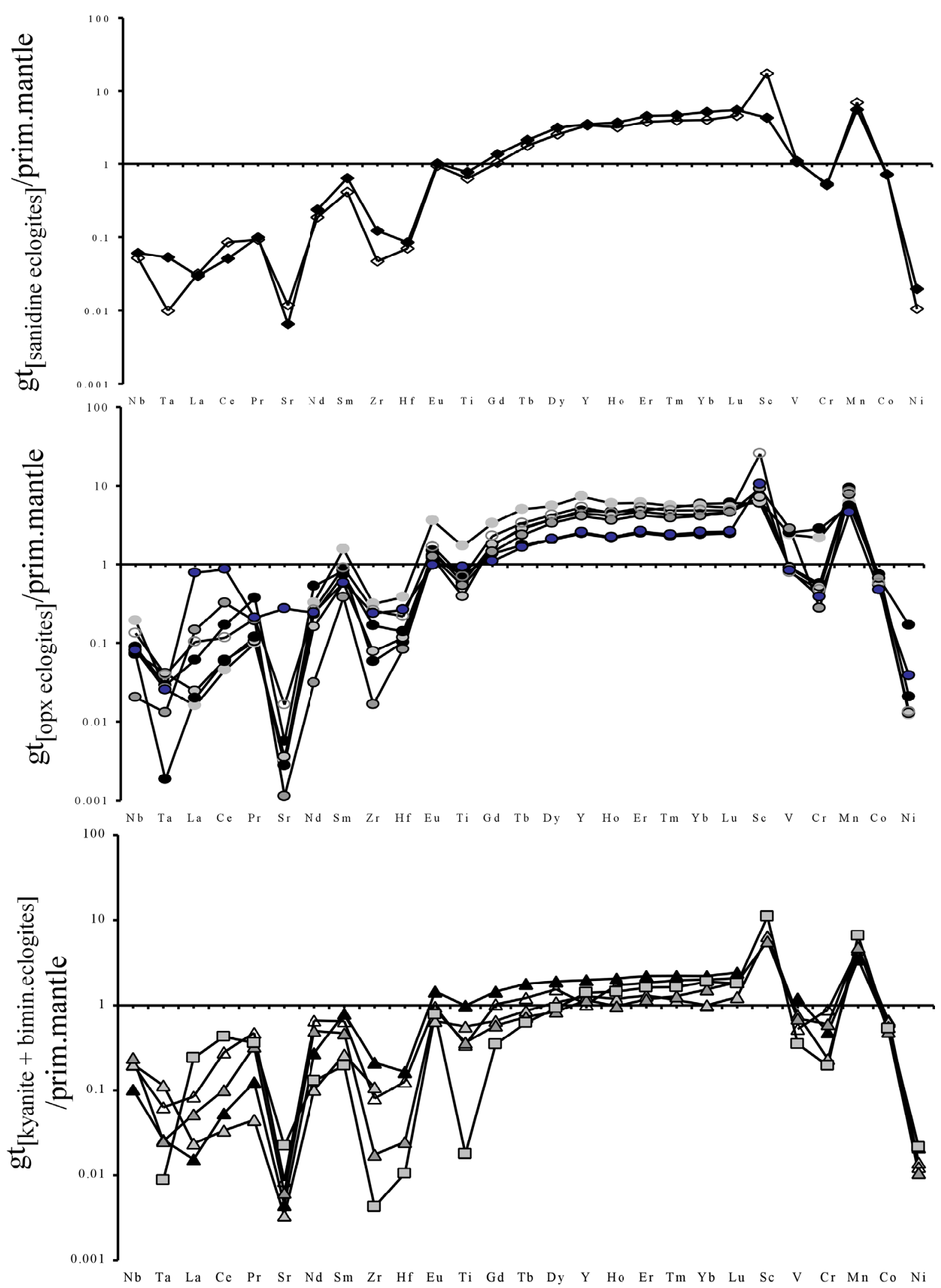

Fig.1 Mantle-normalized (Sun \& McDonough, 1989) spidergrams of average trace element compositions for garnets from sanidine bearing eclogites (top), opx bearing Zero eclogites (middle) and the bimineralic eclogites together with the kyanite eclogite (bottom). 


\subsubsection{Garnet}

Garnets are typically LREE depleted with primitive mantle normalized La contents of 0.02 to 0.07 and 0.01 to 0.85 in sanidine- and orthopyroxenebearing samples. The element patterns (Fig. 1) have a positive slope and are HREE enriched. Bimineralic eclogites show La values from 0.01 to 0.138 whereas the kyanite eclogite Z356 occurs with a La content of 0.25 to 0.29 . Garnets of the kyanite eclogite occur with convex upward slopes in LREE whereas garnet of the bimineralic sample Z298 occurs with a concave downward slope in their LREE.
Primary and secondary garnets in sanidine bearing Zero eclogites

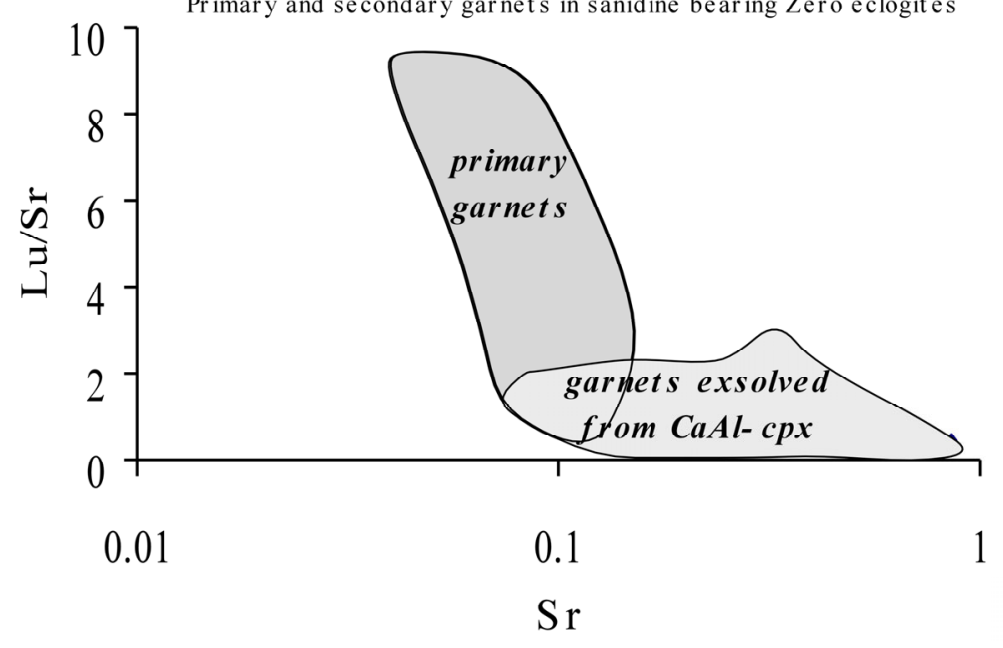

Fig.2 Plot of $\mathrm{Lu} / \mathrm{Sr}$ versus Sr. Primary garnets may be distinguished from secondary garnets, which have mostly higher Lu contents compared to garnets, which exsolved from cpx.

The garnets of sanidine and opx eclogites have rather moderate or slightly enriched HREE (Lu contents of 2.07 to 9.31 and 2.15 to 7.28 ) compared to primitive mantle. The same applies to the bimineralic eclogites with Lu contents from 1.0 to 2.45; and kyanite eclogite 1.5 to 2.19 , which are very close to primitive mantle. Most sanidine eclogites have relatively flat HREE patterns with $\mathrm{Dy} / \mathrm{Yb}$ from 0.42-0.95. All HREE patterns of the opx and sanidine eclogites fall between 1 and 10x primitive mantle. Garnets of the orthopyroxene bearing eclogites show the highest HREE values followed by sanidine eclogites and bimineralic eclogite garnets. The kyanite eclogite occur with the lowest HREE abundance almost below the primitive mantle. Since the garnets are apparently highly equilibrated differences in trace elements between exsolved and primary garnets are rather slight, although some garnets with even less abundant HREE can be distinguished and it can be inferred that they exsolved from clinopyroxenes. Plotting Lu against $\mathrm{Sr}$ the sanidine bearing eclogites form two different groups. Those with high Lu/Sr represent primary garnets whereas those with higher $\mathrm{Sr}$ and low Lu have been exsolved from HREE poor clinopyroxenes (Fig. 2). In contrast to other opx and sanidine eclogites an exceptional garnet of sample ZKE1 has a positive $\mathrm{Eu}$ anomaly $\left(\mathrm{Eu} / \mathrm{Eu}^{*}=3.0\right)$. The kyanite eclogite $\mathrm{Z} 356$ has a slight positive $\mathrm{Eu}$ anomaly $\left(\mathrm{Eu} / \mathrm{Eu}^{*}=1.8\right.$ to 1.4$)$ while garnets from the bimineralic sample Z323 have significant anomalies $\left(\mathrm{Eu} / \mathrm{Eu}^{*}=2.5\right)$. Most garnets of orthopyroxene, sanidine and bimineralic eclogites show variable degrees of $\mathrm{Ti}, \mathrm{Nb}, \mathrm{Ta}, \mathrm{Zr}$ and $\mathrm{Hf}$ depletion, apparently increased by the varied abundance of rutile exsolutions in garnet and clinopyroxene, which concentrate the missing HFSE. Those samples (Z469 and bimineralic eclogites Z298, Z257, Z323 Z239) which occur without rutiles in garnet and clinopyroxene (and without Ti depletion) are depleted in HFSE compared to primitive mantle as well. In correlation with the rutile presence in sanidine and opx eclogites their $\mathrm{Nb}$ and $\mathrm{Ta}$ contents are similarly low and often below the detection limit (maximal values of $0.09 \mathrm{ppm} \mathrm{Nb}$ ). Correlating with the absence of rutiles in garnet of the bimineralic eclogites, $\mathrm{Nb}$ and Ta are slightly higher with maximal normalized values of $0.6(\mathrm{Nb})$ and $0.2(\mathrm{Ta})$. $\mathrm{Zr}$ and $\mathrm{Hf}$ values are very low in the bimineralic eclogites $(\mathrm{Zr}$, Hf $=0.001$ to 0.2 ) and in opx and sanidine eclogites from 0.06 to $0.41(\mathrm{Zr})$ and 0.02 to $0.47(\mathrm{Hf})$. The compatible elements $\mathrm{Cr}$, $\mathrm{Ni}$ and Mn vary between garnets from different eclogite types. Whereas sample Z330 has the highest $\mathrm{Cr}$ content of 7373 ppm followed by sample Z217 with 5681 ppm, the remaining eclogites show values between 511 and 2347 ppm Cr. Ni values fall between 22 and 79 ppm except in sample Z188, which contains 348 ppm. 

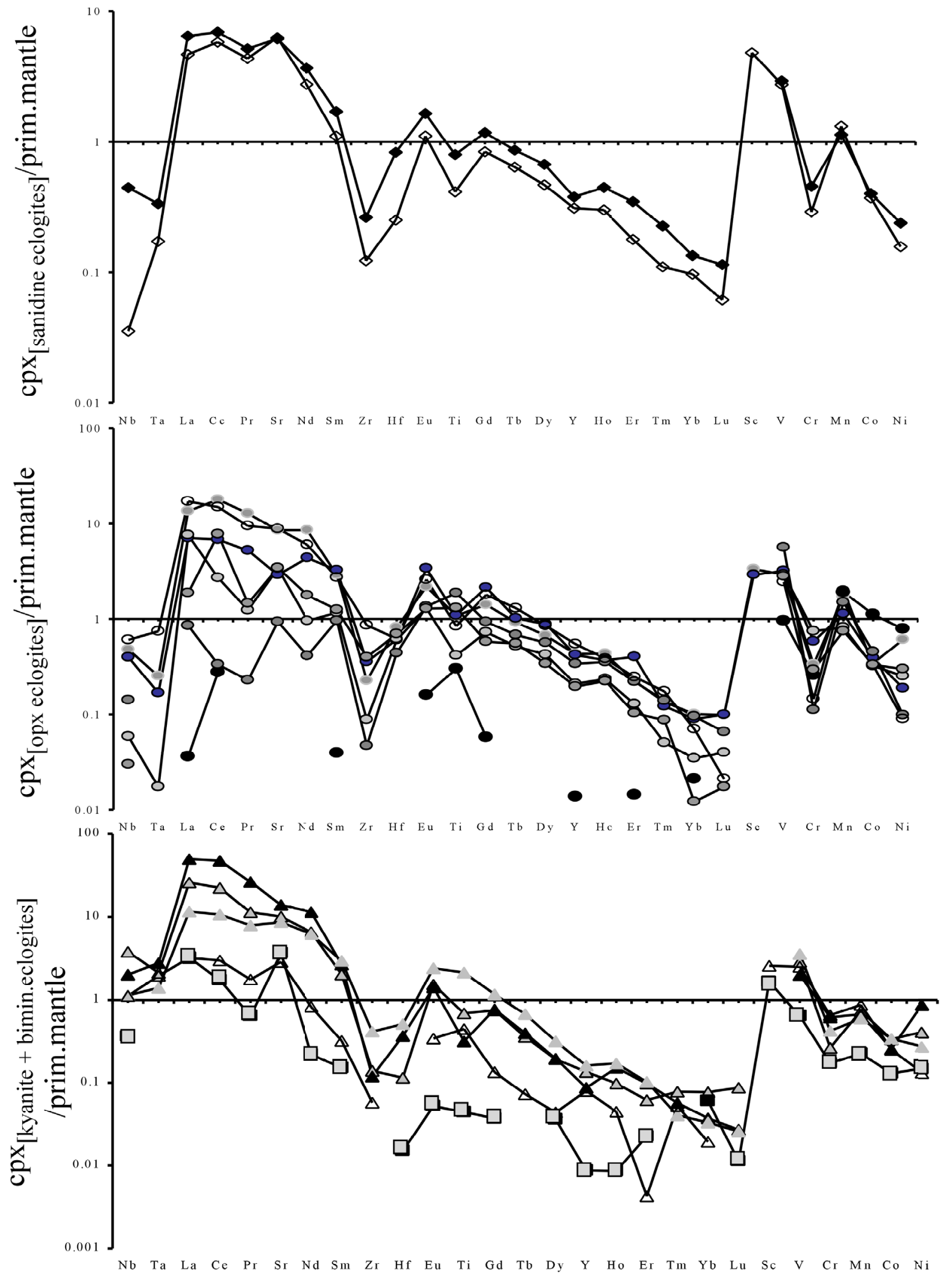

Fig. 3 Mantle-normalized (Sun \& McDonough, 1989) spidergrams of average trace element composition for clinopyroxene from sanidine bearing eclogites (top), opx bearing Zero eclogites (middle) and the bimineralic eclogites with the kyanite eclogite (hottom). 


\subsubsection{Clinopyroxene}

The primitive mantle normalized REE pattern of clinopyroxene (Fig. 3) has typically negative slopes due to LREE enrichment and HREE depletion compared to primitive mantle. La contents range from 3.5 to 10.7 in sanidine eclogites and deviate heavily from 0.03 to 19.01 in orthopyroxene bearing eclogites and in bimineralic eclogites from 2.7 to 59.5 and 3.3 to 3.9 in the kyanite eclogite. Clinopyroxene of different eclogite types are distinguishable in their enrichment of LREE. $\mathrm{La} / \mathrm{Dy}$ ratios vary from 10.0 to 11.5 in sanidine eclogites, and are less more variable than orthopyroxene bearing eclogites (5.5 to 19.5) whereas the bimineralic eclogites show the strongest enrichment with La/Dy values from 68.8 to 72.4 . Particularly the bimineralic eclogite Z239 shows highly enriched LREEs (60x primitive mantle). Positive Eu anomalies are not observed in cpx of most eclogites but are present in the bimineralic sample Z323. This sample is also unusual in showing a negative slope between La and $\mathrm{Nd}$, whereas the orthopyroxene bearing samples Z291 and Z332 even show a strong depletion in LREE. In contrast, sample Z469 shows a flat LREE pattern. Significantly, clinopyroxene of Z330 and the kyanite eclogite Z356 are strongly depleted in REE with most elements below detection limits. Furthermore, no positive $\mathrm{Eu}$ anomalies occur in Z356 and Z323 even though both samples show positive anomalies in garnets. The variable REE shapes of different eclogites might reflect exsolution processes to different extents. The negative anomalies in HFSE of the sanidine and opx eclogites are conspicuous and similar to those in garnets; Z469 shows the lowest values of $\mathrm{Nb}$, Ta, $\mathrm{Zr}$ and Hf. In contrast, cpx of bimineralic eclogites are even enriched in HFSE compared to primitive mantle. Compatible elements of all clinopyroxenes vary significantly; whereas Cr contents vary in the range between 1953 ppm (Z291) and 383 ppm (Z356), the Ni contents vary between 1823 ppm (Z289) and 309 ppm (Z345).

\subsubsection{Accessory phases: sanidine and orthopyroxene}

Sanidine occurs highly enriched in LIL elements especially in $\mathrm{Rb}$ and $\mathrm{Ba}$, and shows similar values measured by SIMS and LAM. In contrast, the values for $\mathrm{Sr}$ differ between these methods, which might either be caused by contamination or is due to different $\mathrm{Sr}$ contents of a zoned sanidine. REE and HFSE analyzed with SIMS appears more reliable since those element concentrations occur below the detection limit, with the exception of Eu, which was rejected due to high values caused by the interference with $\mathrm{Ba}$. The abundances of all trace elements in orthopyroxene are negligibly low and thus not tabulated.

\section{Discussion}

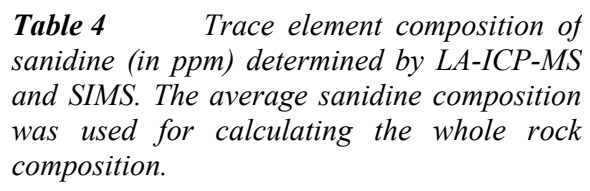

Table 4 Trace element composition of sanidine (in ppm) determined by LA-ICP-MS and SIMS. The average sanidine composition was used for calculating the whole rock composition.

\begin{tabular}{cccccc|}
\hline sanidine & SIMS & LAM & sanidine & SIMS & LAM \\
\hline $\mathrm{Cs}$ & 13.75 & 30.73 & $\mathrm{Sm}$ & 0.03 & 0.26 \\
$\mathrm{Rb}$ & 623 & 1547 & $\mathrm{Zr}$ & 0.02 & - \\
$\mathrm{Ba}$ & 2197 & 1751 & $\mathrm{Hf}$ & 0.06 & 0.37 \\
$\mathrm{Th}$ & - & 0.014 & $\mathrm{Eu}$ & 0.71 & 0.06 \\
$\mathrm{Nb}$ & - & 0.12 & $\mathrm{Gd}$ & - & 0.02 \\
$\mathrm{Ta}$ & - & 0.03 & $\mathrm{Y}$ & 0.04 & - \\
$\mathrm{La}$ & 0.07 & 0.07 & $\mathrm{Ho}$ & - & 0.01 \\
$\mathrm{Ce}$ & 0.04 & 0.19 & $\mathrm{Er}$ & - & 0.01 \\
$\mathrm{~Pb}$ & - & 2.01 & $\mathrm{Tm}$ & - & 0.02 \\
$\mathrm{Pr}$ & - & 0.02 & $\mathrm{Yb}$ & - & 0.01 \\
$\mathrm{Sr}$ & 51.75 & 39.74 & $\mathrm{Lu}$ & - & 0.01
\end{tabular}

\subsection{Partition coefficients}

The clinopyroxene/garnet partitioning of all samples show a wide range of $\mathrm{D}^{\mathrm{cp} / \mathrm{gt}}$ values particularly in highly incompatible elements. The variation decreases approximately with the compatibility of each element. The changes in cpx/gt partition coefficients for trace elements are particularly associated with changes in $\mathrm{Ca} /(\mathrm{Ca}+\mathrm{Mg})$ in garnet and clinopyroxene, such that the $\mathrm{D}_{i}{ }^{\mathrm{cpx} / \mathrm{gt}}$ decreases as the $\mathrm{Ca} /\left(\mathrm{R}^{2+}\right)$ increase. Such a close relationship between $\mathrm{D}_{\mathrm{i}}$ and the $\mathrm{D}_{\mathrm{Ca}}$ is expected from consideration 
of ionic radii and prove that most trace elements are substituting in the Ca-bearing sites, which are [8]-fold coordinated in both clinopyroxene and garnet. The trace element partitioning $\left(\mathrm{D}^{\mathrm{cpx} / \mathrm{gt}}\right)$ of $\mathrm{Sr}, \mathrm{Nd}, \mathrm{Eu}$ and $\mathrm{Y}$ in most Zero eclogites show good correlation to the molar $\mathrm{Ca}$ partition coefficient $\left(\mathrm{D}_{\mathrm{Ca}^{*}}\right)$, (which varies from 0.47 in the kyanite eclogite (Z356), 0.78 in the bimineralic eclogite (Z323) and 2.33 in the remaining eclogites), similar to the trend established for Roberts Victor eclogites (Harte

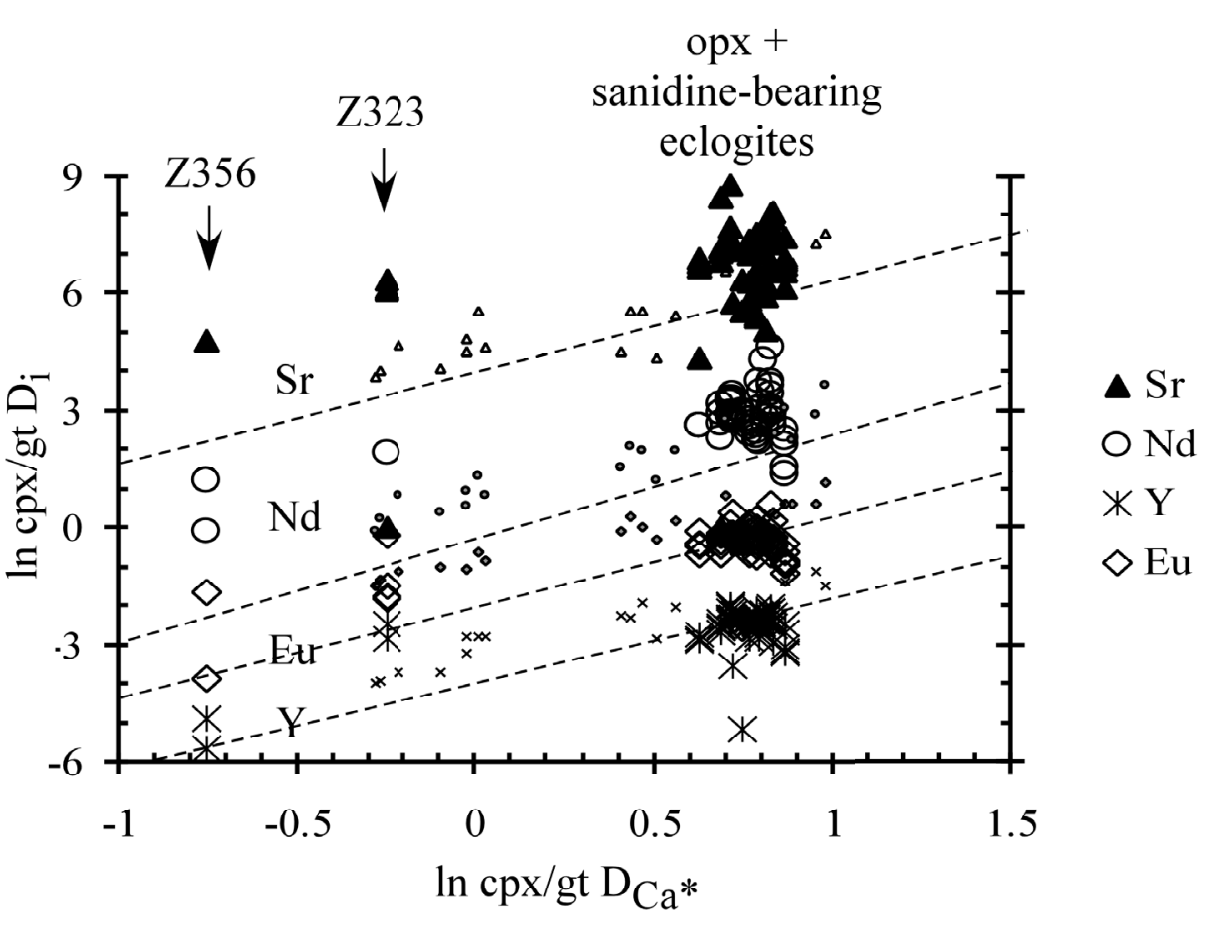

Fig. $4 \quad$ Natural log of Cpx/gt partition coefficients (in ppm) for $\mathrm{Sr}$, $N d, E u$ and $Y$ plotted versus natural log of molar partition coefficient for $\mathrm{Ca}^{c p x / g t}$. Data from Zero eclogites (big symbols) compared to Roberts Victor eclogites (small symbols). Dashed lines are the regression lines of Harte \& Kirkley (1979) shown by Roberts Victor eclogites. Except samples Z356 and Z323 Zero eclogites show a correlation to the Ca composition and agree with the trend established by Harte \& Kirkley (1979).

and Kirkley, 1997, Fig.4). The systematic variation is supposed to be typical for high-temperature equilibrium trace element partitioning in eclogite xenoliths (Harte and Kirkley, 1997). That sample Z356 and Z323 occur with lower partition coefficients than the remaining samples is caused by the higher jadeite component in clinopyroxene of both samples since the substitution of $\mathrm{Na}$ and $\mathrm{Al}^{[\mathrm{VI}]}$ in clinopyroxene is coupled with an increasing $\mathrm{Ca}$ content in garnet alone. The variation of the $\mathrm{D}^{\mathrm{cpx} / \mathrm{gt}}$ values from the same eclogite types is further caused by different trace element partitioning during equilibrium melting and crystallization and during metamorphism and sub-solidus reactions. Deviations from the trend observed in Roberts Victor eclogites are apparently caused by higher equilibration temperatures of the Zero eclogites compared to Roberts Victor eclogites. A definite temperature effect is recognizable in the $\mathrm{D}$ values of compatible elements $\mathrm{Cr}$ and $\mathrm{Ni}$, whereas Co and $\mathrm{Mn}$ show a similar correlation to the incompatible elements. The $\mathrm{D}^{\mathrm{cpx} / \mathrm{gt}}$ values for $\mathrm{Cr}$ varies between different eclogite types in the range of 0.09 (Z330) and 1.13 (Z298) and Ni range from 0.21 to 126.7 in Z188 and from 6.4 to 46 in the remaining eclogites.

\subsection{Trace element whole rock composition}

Trace element whole rock compositions of the sanidine and orthopyroxene bearing eclogites were reconstructed by combining average mineral compositions performed by LAM + SIMS with modal percentages determined by element mapping with EPMA and phase map analyses that assigns each data point to a particular phase (Zack et al., 1998). Both sanidine eclogites were calculated with average modal percentages of $62 \mathrm{wt} \% \mathrm{cpx}, 33 \mathrm{wt} \% \mathrm{gt}, 4 \mathrm{wt} \%$ opx and $1 \mathrm{wt} \%$ san. Orthopyroxene bearing eclogites without sanidine have average modal proportions of $58 \mathrm{wt} \% \mathrm{cpx}, 37 \mathrm{wt} \% \mathrm{gt}$ and $5 \mathrm{wt} \%$ opx, the kyanite grospydite was calculated as $74 \mathrm{wt} \% \mathrm{cpx}, 16 \mathrm{wt} \% \mathrm{gt}, 9 \mathrm{wt} \% \mathrm{ky}$ and $1 \mathrm{wt} \%$ sanidine. Bimineralic eclogites were estimated as $60 \mathrm{wt} \% \mathrm{cpx}$ and $40 \mathrm{wt} \% \mathrm{gt}$, which is based on optical estimation. 


\begin{tabular}{|c|c|c|c|c|c|c|c|c|c|c|c|c|c|c|}
\hline $\begin{array}{c}\text { whole } \\
\text { rock }\end{array}$ & $\begin{array}{c}\text { ZKE1 } \\
\text { san }\end{array}$ & $\begin{array}{c}\text { Z267 } \\
\text { san }\end{array}$ & $\begin{array}{c}\mathbf{Z 1 8 8} \\
\text { opx }\end{array}$ & $\begin{array}{c}\mathbf{Z 2 1 7} \\
\text { opx }\end{array}$ & $\begin{array}{c}\text { Z291 } \\
\text { opx }\end{array}$ & $\begin{array}{c}\mathbf{Z 3 3 0} \\
\text { opx }\end{array}$ & $\begin{array}{c}\mathbf{Z 3 3 2} \\
\text { opx }\end{array}$ & $\begin{array}{c}\text { Z341 } \\
\text { opx }\end{array}$ & $\begin{array}{c}\mathbf{Z 4 6 9} \\
\text { оpx }\end{array}$ & $\begin{array}{c}\mathbf{Z 2 9 8} \\
\text { bimin }\end{array}$ & $\begin{array}{l}\mathbf{Z 2 3 9} \\
\text { bimin }\end{array}$ & $\begin{array}{l}\mathbf{Z 2 5 7} \\
\text { bimin }\end{array}$ & $\begin{array}{l}\mathbf{Z 3 2 3} \\
\text { bimin }\end{array}$ & $\begin{array}{c}\overline{\text { Z356 }} \\
\text { ky }\end{array}$ \\
\hline Cs & .566 & .585 & - & - & - & - & 0.010 & - & - & 0.001 & - & 0.002 & 0.026 & - \\
\hline $\mathbf{R b}$ & 23.60 & 23.47 & - & - & - & - & - & - & - & 0.02 & - & 0.09 & 1.56 & 0.04 \\
\hline $\mathbf{B a}$ & 28.88 & 28.84 & 0.14 & - & 0.22 & 0.04 & 0.18 & 0.38 & 0.16 & 0.14 & 0.15 & 0.22 & 0.88 & 1.35 \\
\hline Th & 0.055 & 0.189 & 0.214 & 0.254 & 0.279 & 0.011 & 0.059 & 0.630 & 0.126 & 0.578 & 1.419 & 0.589 & 0.150 & 0.710 \\
\hline $\mathbf{U}$ & 0.006 & 0.020 & 0.045 & 0.031 & 0.039 & 0.012 & 0.003 & 0.082 & 0.045 & 0.105 & 0.253 & 0.086 & 0.079 & 0.117 \\
\hline $\mathbf{N b}$ & 0.021 & 0.211 & 0.222 & 0.216 & 0.042 & 0.020 & 0.036 & 0.272 & 0.021 & 1.471 & 0.936 & 0.515 & 0.297 & 0.253 \\
\hline $\mathbf{T a}$ & 0.003 & 0.009 & 0.006 & 0.004 & 0.000 & 0.000 & 0.000 & 0.018 & 0.000 & 0.052 & 0.094 & 0.035 & 0.033 & 0.001 \\
\hline La & 1.994 & 2.787 & 5.404 & 2.853 & 2.861 & 0.050 & 0.406 & 6.849 & 1.058 & 11.02 & 18.94 & 4.820 & 1.115 & 1.815 \\
\hline $\mathrm{Ce}$ & 6.332 & 7.683 & 18.45 & 7.073 & 2.690 & 0.359 & 0.590 & 15.41 & 8.818 & 26.61 & 44.88 & 11.5 & 3.016 & 2.617 \\
\hline $\mathbf{P b}$ & 0.282 & 0.496 & 0.449 & 0.506 & 0.783 & 0.223 & 0.141 & 0.942 & 0.303 & 0.681 & 0.941 & 0.964 & 0.177 & 0.389 \\
\hline Pr & 0.737 & 0.891 & 2.080 & 0.850 & 0.199 & 0.015 & 0.059 & 1.538 & 0.257 & 2.064 & 4.148 & 1.325 & 0.286 & 0.158 \\
\hline $\mathrm{Sr}$ & 83.12 & 81.05 & 105.5 & 36.89 & 39.97 & 1.041 & 12.38 & 109.1 & 46.30 & 140.3 & 215.9 & 109.7 & 31.37 & 62.75 \\
\hline Nd & 2.37 & 3.17 & 6.98 & 3.63 & 0.81 & & 36 & 4.91 & 1.53 & 5.97 & 9.42 & 5.18 & 0.77 & 0.26 \\
\hline Sm & 0.36 & 0.57 & 0.91 & 1.11 & 0.40 & 0.15 & 0.33 & 0.91 & 0.41 & 0.61 & 0.93 & 0.94 & 0.18 & 0.07 \\
\hline $\mathbf{Z r}$ & 1.18 & 2.31 & 1.74 & 3.63 & 0.91 & 71 & 40 & 6.97 & 3.56 & 1.28 & 1.12 & 3.77 & 0.41 & 0.03 \\
\hline Hf & 0.12 & 0.18 & 0.17 & 0.15 & 0.13 & 0.03 & 0.10 & 0.15 & 0.17 & 0.03 & 0.07 & 0.11 & 0.00 & 0.01 \\
\hline $\mathbf{E u}$ & 0.17 & 0.24 & 0.32 & 0.57 & 0.22 & 0.10 & 0.22 & 0.38 & 0.18 & 0.20 & 0.19 & 0.34 & 0.10 & 0.02 \\
\hline $\mathbf{T i}$ & 1063 & 1370 & 989 & 1333 & 424 & 442 & 1569 & 872 & 1293 & 593 & 391 & 1951 & 474 & 26 \\
\hline Gd & 0.53 & 0.73 & 0.89 & 1.49 & 0.67 & 0.34 & 0.66 & 1.24 & 0.34 & 0.41 & 0.49 & 0.75 & 0.16 & 0.04 \\
\hline $\mathbf{T b}$ & 0.11 & 0.14 & 0.18 & 0.27 & 0.15 & 0.07 & 0.14 & 0.24 & 0.07 & 0.06 & 0.07 & 0.11 & 0.03 & 0.01 \\
\hline Dy & 0.85 & 1.12 & 1.31 & 1.89 & 1.26 & 0.57 & 1.16 & 1.71 & 0.44 & 0.40 & 0.52 & 0.58 & 0.26 & 0.11 \\
\hline $\mathbf{Y}$ & 5.33 & 5.80 & 7.92 & 11.54 & 7.42 & 3.67 & 6.75 & 10.50 & 2.22 & 2.35 & 1.85 & 2.65 & 1.82 & 0.74 \\
\hline Но & 0.21 & 0.26 & 0.32 & 0.40 & 0.29 & 0.13 & 0.25 & 0.37 & 0.09 & 0.08 & 0.13 & 0.11 & 0.07 & 0.03 \\
\hline Er & 0.67 & 0.88 & 0.92 & 1.19 & 0.90 & 0.45 & 0.80 & 1.17 & 0.27 & 0.27 & 0.37 & 0.30 & 0.23 & 0.11 \\
\hline Tm & 0.11 & 0.13 & 0.15 & 0.16 & 0.13 & 0.06 & 0.11 & 0.17 & 0.04 & 0.04 & 0.06 & 0.04 & 0.04 & 0.00 \\
\hline $\mathbf{Y b}$ & 0.75 & 0.96 & 1.09 & 1.03 & 0.87 & 0.44 & 0.77 & 1.08 & 0.27 & 0.20 & 0.40 & 0.25 & 0.35 & 0.14 \\
\hline Lu & 0.12 & 0.15 & 0.17 & 0.15 & 0.15 & 0.07 & 0.13 & 0.16 & 0.04 & 0.04 & 0.06 & 0.04 & 0.07 & 0.02 \\
\hline Sc & 136.0 & 44.8 & 61.4 & 59.8 & - & - & - & - & - & 38.6 & - & - & 54.6 & 41.5 \\
\hline $\mathbf{V}$ & 171 & 194 & 187 & 245 & 180 & 141 & 373 & 158 & 179 & 171 & 130 & 213 & 147 & 48 \\
\hline $\mathrm{Cr}$ & 955 & 1203 & 1070 & 3004 & 1512 & 3136 & 452 & 471 & 787 & 638 & 1995 & 1172 & 1686 & 478 \\
\hline Mn & 3384 & 2783 & 4751 & 3170 & 4016 & 3396 & 4001 & 5067 & 1579 & 2399 & 2253 & 1566 & 2645 & 1078 \\
\hline Co & 54 & 54 & 49 & 51 & 42 & 98 & 55 & 43 & 39 & 48 & 41 & 41 & 37 & 18 \\
\hline $\mathbf{N i}$ & 241 & 331 & 874 & 251 & 308 & 976 & 132 & 130 & 415 & 355 & 251 & 358 & 188 & 253 \\
\hline
\end{tabular}

Table 4 Reconstructed whole rock composition of the Zero eclogites (in ppm) from minerals determined by LAICP-MS. Modal proportions for the bimineralic eclogites are $60 \mathrm{wt} \% \mathrm{cpx}$ and $40 \mathrm{wt} \% \mathrm{gt}$, for sanidine bearing eclogites: $62 \mathrm{wt} \%$ cpx, $33 \mathrm{wt} \% \mathrm{gt}, 4 \mathrm{wt} \%$ opx and $1 \mathrm{wt} \%$ sanidine, for opx bearing eclogites: 58 $w t \%$ cpx, $37 \mathrm{wt} \% \mathrm{gt}$, and $5 \mathrm{wt} \%$ opx and for the kyanite bearing eclogite: $74 \mathrm{wt} \% \mathrm{cpx}, 16 \mathrm{wt} \% \mathrm{gt}, 9 \mathrm{wt} \%$ ky and 1 wt\% sanidine.

\subsubsection{Sanidine and orthopyroxene bearing eclogites}

The sanidine bearing eclogites (Fig. 6a) show a convex-upward slope in the slight enriched LREE patterns and relatively flat HREE patterns. Orthopyroxene eclogites show an element pattern similar to those of the sanidine eclogites. Samples Z188, Z217, Z291, Z332 and Z341 occur with HREE abundance similar to both sanidine eclogites whereas Z330 and Z469 are even depleted relative to primitive mantle. Hence, based on the REE element patterns, two different orthopyroxene bearing eclogites may be distinguished. The latter samples are also not strongly enriched in LREE but Z332 even shows a strong depletion in LREE and occurs with an unusual convex slope, similar to the less depleted sample Z291. Regardless of their differences in HREE patterns, the samples Z332, Z291 and Z469 have similarly enriched Sr values in contrast to samples Z330 and Z217, which occur with distinct HREE contents but both show negative Sr anomalies (Fig. 6b). In contrast to this, sample Z217 shows a slight positive Eu- anomaly. 


\subsubsection{Bimineralic eclogites and the kyanite eclogite}

The bimineralic eclogites (Z323, Z257, Z239, Z298) have high LREE/HREE ratios, which initially appear similar to a melt signature yielded from a cryptic metasomatism where light REEs and LILEs are enriched without the presence of metasomatic phases (Frey and Green, 1974; Dawson, 1984). In contrast, the MREE and HREE of the bimineralic eclogites show slight negative slopes and occur depleted compared to sanidine and orthopyroxene- bearing eclogites. Whereas samples Z298, Z257 and Z239 are strongly enriched in LREE (7-30 x primitive mantle, Fig. 6c) sample Z323 has low LREE and is most depleted in HREE compared to remaining bimineralic samples, and is further distinguished by the occurrence of a positive $\mathrm{Sr}$ and $\mathrm{Eu}-$ anomalies $\left(\mathrm{Eu} / \mathrm{Eu}^{*}=1.6\right)$.
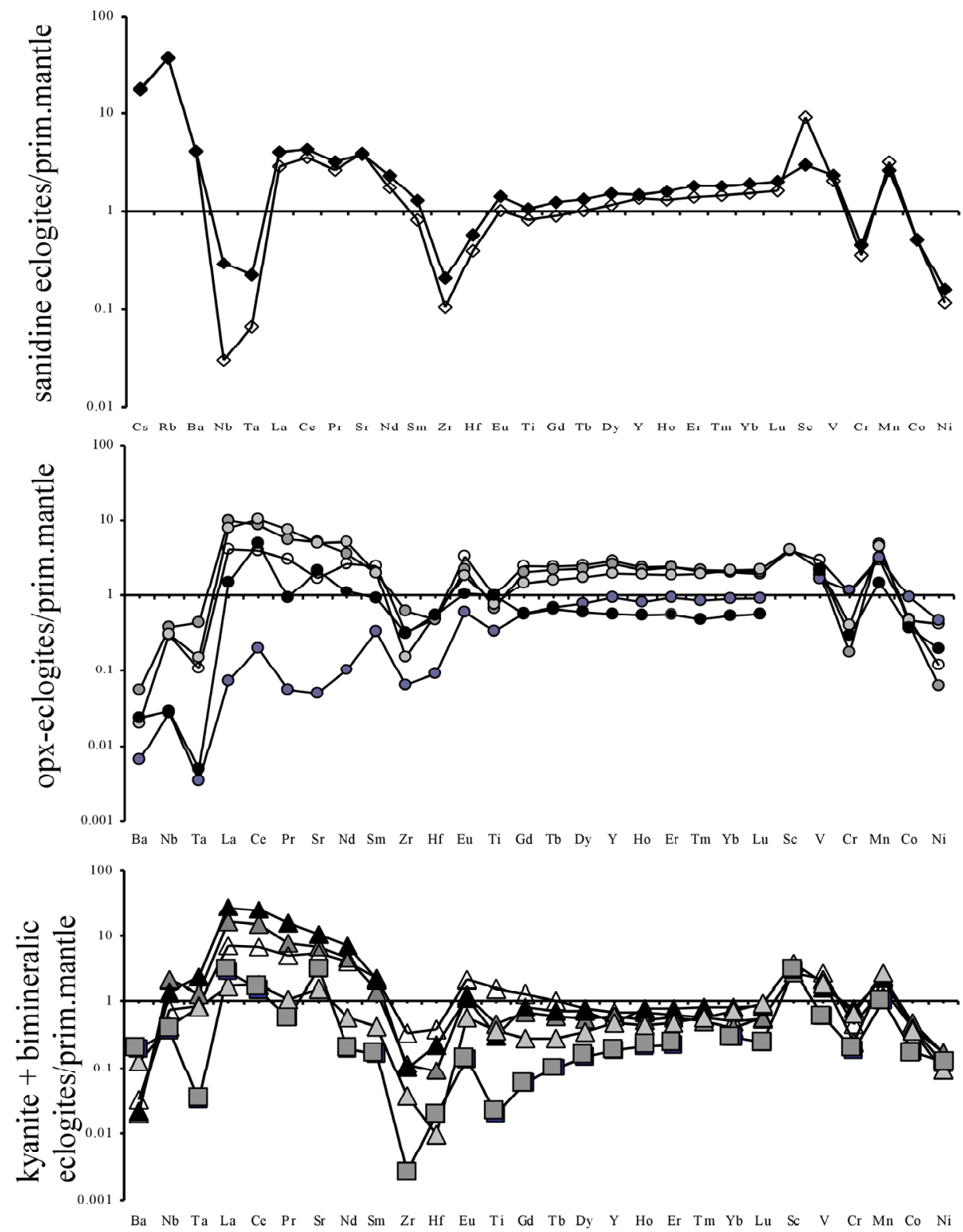

Fig. 5 Mantle-normalized (Sun \& McDonough, 1989) spidergrams of reconstructed whole rock compositions for Zero sanidine-bearing eclogites (top), opx bearing eclogites (middle) and bimineralic eclogites together with the kyanite eclogite (bottom). Modal proportions for the bimineralic eclogites were estimated assuming 60wt\% cpx and 40wt\% gt. Modal proportions for the polyphase eclogites were estimated by EPMA phase map analysis (see Table 4). All eclogites show very low Nb and Ta, which is reinforced by the missing rutile analysis in the whole rock composition. Except sample Z323 and Z356 the LREE elements of most eclogites are strongly affected by metasomatism in distinct extent. 

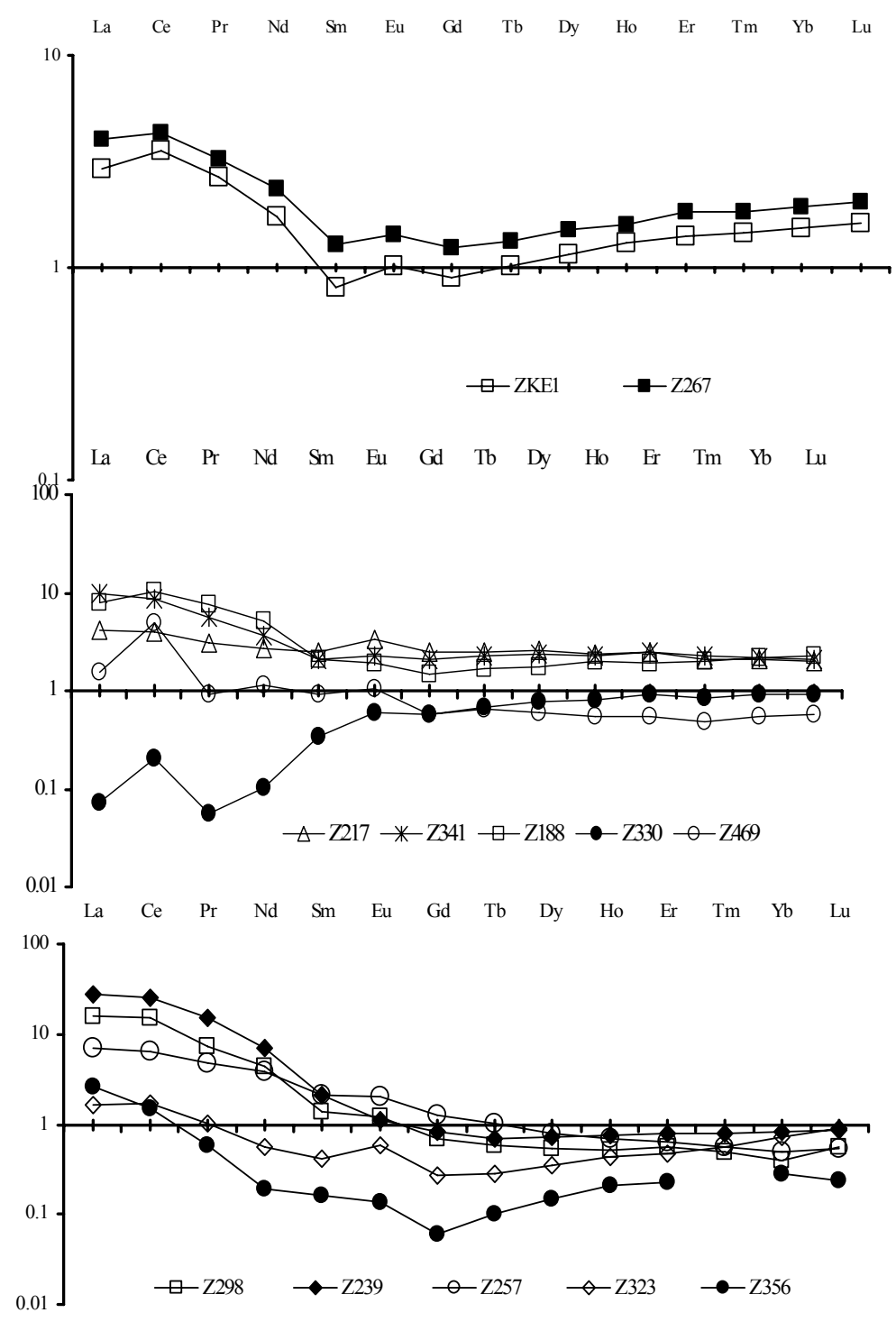

La $\quad$ Ce $\quad$ Pr $\quad$ Nd $\quad \begin{array}{llllllllll}\mathrm{Sm} & \mathrm{Fu} & \mathrm{Gd} & \mathrm{Tb} & \mathrm{Dy} & \mathrm{Hb} & \mathrm{Er} & \mathrm{Tm} & \mathrm{Yb} & \mathrm{Lu}\end{array}$

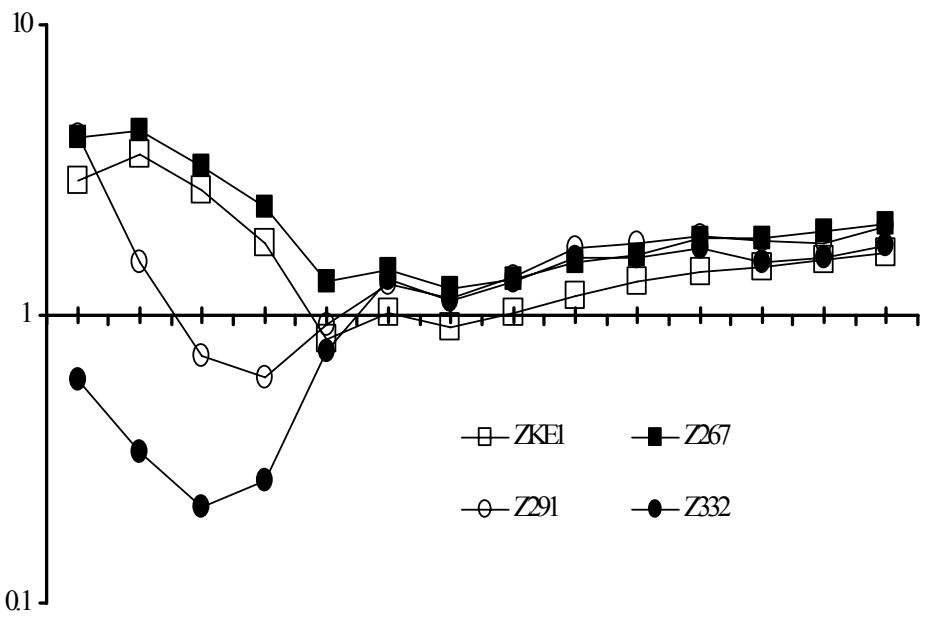

Fig. 6a-d show mantle normalized (Sun and McDonough, 1989) diagrams of REE whole rock compositions of the Zero eclogites.

Fig. 6a Both sanidine bearing eclogites have similar element patterns with HREEs close to the primitive mantle and LREEs, which are slightly overprinted by metasomatism.

Fig. $\boldsymbol{6} \boldsymbol{b}$ Two different opx-bearing eclogites can be distinguished on their HREE abundances. Most samples show various enrichments in LREEs except Z332, Z291 and Z330.

Fig. 6c The bimineralic eclogite Z323 and the kyanite eclogite Z356 show similar depleted HREEs, and occur almost not enriched in LREEs. Exclusively both eclogites have a slight positive Eu-anomaly, indicating plagioclase in the precursory phase.

Fig. 6d That opx-bearing eclogites Z332 and Z291 have similar HREEs to sanidine bearing eclogites ZKE1 and Z267 but distinguish in LREE, argue for that both eclogite types derived from the same source, which were overprinted later by metasomatism in distinct extent. Though, the depletion in LREE elements might be caused by a small loss of partial melt, however considering the remaining quartz inclusions in the eclogites the unusual low LREEs should be rather due to an enrichment (of La and Ce) by metasomatism to a lesser extent. 
The kyanite eclogite (Z356, Fig. 6c) has the most depleted REE abundance compared to primitive mantle and to the remaining eclogites and shows positive $\mathrm{Sr}$ and slight $\mathrm{Eu}$ anomalies $\left(\mathrm{Eu} / \mathrm{Eu}^{*}=1.2\right)$. The occurrence of positive $\mathrm{Sr}$ and $\mathrm{Eu}$ anomalies in the bimineralic- and the kyanite eclogite indicates plagioclase accumulation in the protolith and a highly fractionated plagioclase rich protolith could be proposed for the latter eclogites, which might argue for a crustal precursor for the Zero Suite. If the protoliths of samples Z323 and Z356 were gabbroic plagioclase-bearing cumulates the MgO rich bimineralic eclogites Z298, Z257, and Z239 might represent cumulates from deeper parts of the oceanic crust. This would

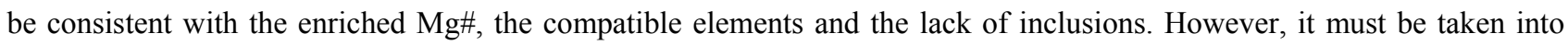
account that the enrichment of LREE in the other bimineralic eclogites might mask ancient positive Sr- and Eu-anomalies that would lead to a distinct interpretation.

Summarizing the whole-rock trace element compositions the eclogites could be subdivided into 5 types, correlating with the petrographical groups, consisting of two orthopyroxene eclogite types, two distinct bimineralic eclogite types and the kyanite eclogite. Due to the chemical similarity most orthopyroxene bearing eclogites with or without sanidine (plus quartz, rutile cpx and K-feldspar inclusions) (ZKE1, Z267, Z291, Z332) could be distinguished from those orthopyroxene bearing eclogites which show a depletion in HREE and slightly enriched compatible elements (Z469 and Z330). The Caand jadeite rich bimineralic eclogite Z323 showing a slight positive Eu- and Sr- anomaly and low LREE could be distinguished from $\mathrm{MgO}$-rich bimineralic eclogites, which occur with less variable compositions. The strongly depleted and Ca-garnet rich kyanite grospydite Z356 shows slight positive Eu and $\mathrm{Sr}$ anomalies.

\subsection{Genetic relationship}

Whether eclogite xenoliths sampled by the kimberlite are in fact genetically related is difficult to prove and was merely assumed since they appear together within one pipe. However, considering the similarity of whole rock trace element patterns a genetic relation between sanidine- and most orthopyroxene bearing eclogites can be inferred. However, these samples cannot be parental to the remaining, inclusion free eclogites (Z188, Z217, Z341 and bimineralic eclogites), which show slightly different chemical compositions. If the different eclogite types were related to each other the resulting element patterns should coincide in HREE (Gd). A direct descent from sanidine bearing eclogites can also be excluded for the bimineralic eclogites (Z239, Z298, Z257 and Z323). If the bimineralic eclogites were residues produced by melting of the sanidine bearing eclogites the resulting element pattern should have enriched

Fig. 7 Zero Eclogites compared to eclogites xenoliths from Udachnaya and Mir kimberlites (Siberia craton). Sanidine- and some opx-bearing Zero eclogites matching best to Russian eclogites. The bimineralic eclogite Z323 and the kyanite eclogite Z356 are not comparable with Russian and African eclogites.

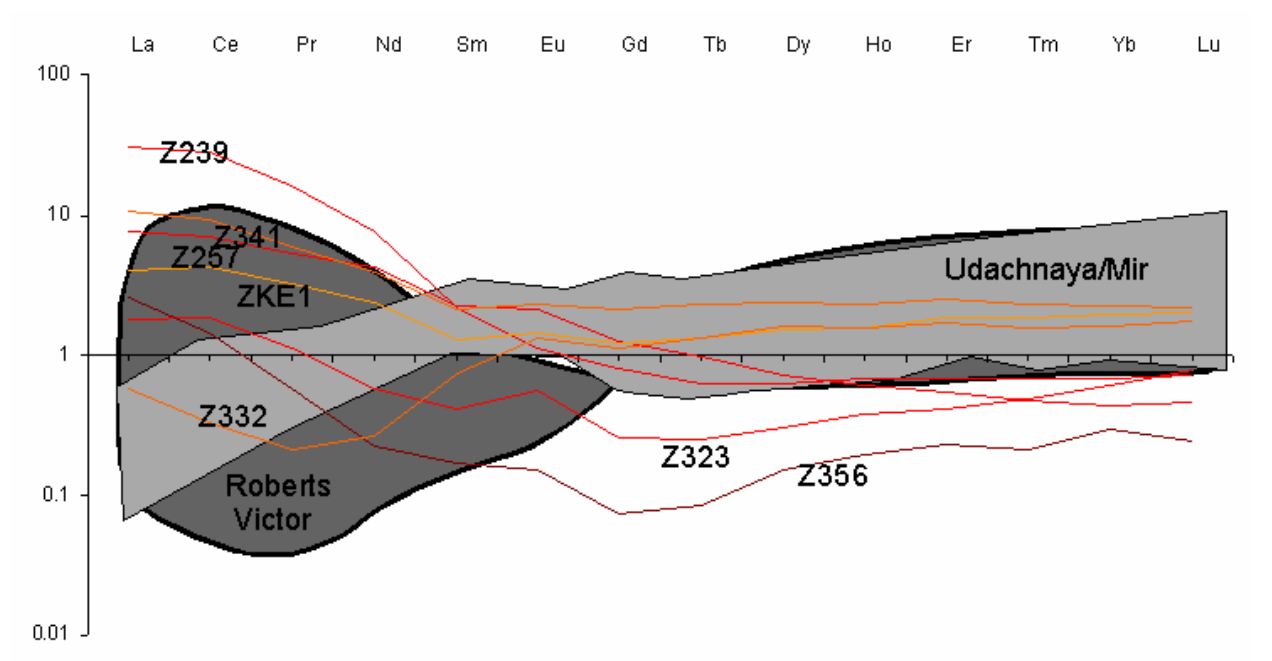


HREE with depleted LREE, opposite to those seen in the trace element patterns of the bimineralic eclogites. Therefore, starting from the assumption Zero eclogites are genetically related, a reasonable explanation for the varying trace element pattern of different eclogites would be that they represent fractionated igneous cumulates from different lower crustal levels or derived from slightly different protolith due to evolving fractionation.

Compared to the trace element composition of eclogite xenoliths sampled from different kimberlites, the

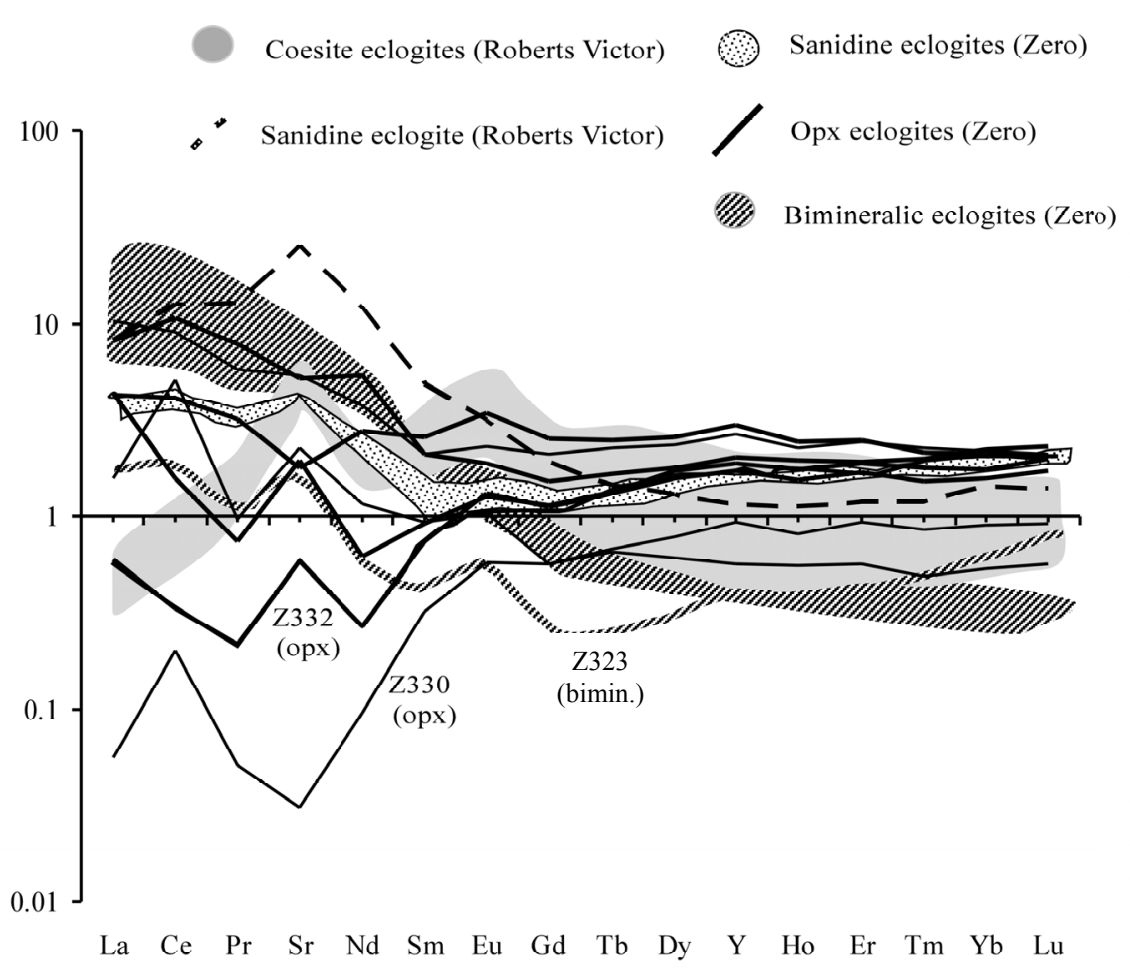

Fig. 8 Spidergrams of coesite eclogites sampled by Roberts Victor kimberlite compared to Zero eclogites. RV-coesite eclogites have positive Eu anomalies and occur less metasomatized. The sanidine eclogite from Roberts Victor show different LREE- but similar HREE abundance compared to sanidine eclogites from the Zero suite.

Zero sanidine eclogites

resemble most closely the trace element patterns of the bimineralic eclogites from Udachnaya, (Siberia craton; Fig. 7) (Snyder et al., 1997, Jacob and Foley 1999). In contrast, the bimineralic eclogites show similar LREE but have lower MREE and HREE than the most depleted Udachnaya eclogites. In comparison to eclogites from the Roberts Victor kimberlite (R.S.A., Kaapvaal craton) the most compelling difference to the Zero eclogite suite consists in the significant positive Eu- anomalies of the Roberts Victor suite, typical for the gabbroic part of the recycled oceanic crust (Fig. 8; Harte and Kirkley, 1997, Jacob et al 2002). Unfortunately, trace element data from non-diamondiferous Jagersfontain eclogites are not available, which are rather similar to Zero eclogites concerning their modality, major element chemistry and exsolution textures.

\subsection{Processes and protoliths for the eclogites indicated by trace element abundances}

For the purpose to ascertaining a feasible source for the eclogites by trace elements it is important to take into account all processes (including seawater alteration, dehydration, melt loss, metasomatism), which could have affected the trace element abundance of the eclogites at different stages. The oxygen isotopes of the eclogites yield the composition of the mantle, but this need not mean that the eclogites are compellingly not seawater altered but apparently, the trace element abundance should not have been affected seriously by seawater alteration, nor were they modified heavily by dehydration reactions.

Due to the restricted $\delta^{18} \mathrm{O}$ values the mobility of different elements can also not easily be tested. Since HFSE are considered to be the least mobile elements in geological settings, which was confirmed for seawater altered eclogite 
xenoliths from Udachnaya (Jacob and Foley, 1999) it can be assumed that these elements are least changed later on. Hence the low HFSE abundance appears to be crucial for the Zero eclogite suite since all eclogites are depleted in HFSE (Zr, Hf, $\mathrm{Nb}$ and $\mathrm{Ta}$ ) to varying extents (Z330, Z332, Z469 are strongly depleted), which is not likely to be due to lacking rutile $(<5 \mu \mathrm{m})$ trace elements alone. This is shown by the bimineralic eclogites (Z298, Z257, Z239 and Z323) and Z469, which occur with depleted $\mathrm{Zr}, \mathrm{Hf}, \mathrm{Nb}$ and Ta ratios compared to primitive mantle even though rutile (and a negative Ti anomaly) is lacking. However, bimineralic samples Z298 and Z239 are less depleted in Nb and Ta compared to remaining eclogites but show similar low $\mathrm{Zr}$ and Hf contents.

Nevertheless, depleted HFSE, which are highly compatible in $\mathrm{TiO}_{2}$-rich minerals like rutile and ilmenite, occur as a feature of melts derived from eclogites and thus may indicate geological settings. Since fractionation between $\mathrm{HFSE}^{4+}$ and $\mathrm{HFSE}^{5+}$, which is produced by rutile (Foley et al., 2000) is a common feature in island arc volcanics and intra-plate alkaline melts, the $\mathrm{Nb} / \mathrm{Ta}$ and $\mathrm{Zr} / \mathrm{Hf}$ ratios are useful to distinguish subduction related processes (Niu and Batiza, 1997, Foley, 2000). Nevertheless, the low HFSE abundance, $\mathrm{Nb} / \mathrm{Ta}$ and $\mathrm{Zr} / \mathrm{Hf}$ ratios of the Zero suite might be attributed to a depleted source.

\section{Metasomatic overprinting}

Overprinting of most sanidine and orthopyroxene bearing eclogites by a late metasomatic event is demonstrated by the occurrence of metasomatic phlogopite, which has been produced either by the incorporation of the kimberlitic host-magma or by a previous event. Most samples show some LREE enrichment (except samples Z330, Z332) despite the lack of indicative metasomatic minerals, showing that most eclogites experienced variable degrees of a "cryptic" metasomatism at a late stage. The overprint was apparently produced during an ancient metasomatic event prior to the entrainment in the host kimberlite, which is argued since most REE enriched eclogites (except ZKE1 and Z267) are not enriched in highly incompatible elements like $\mathrm{Ba}, \mathrm{Sr}, \mathrm{Nb}, \mathrm{Ta}$, which would be added with kimberlite magmas. The lack of the mobile LILE might be due to their loss during dehydration of the protolith. Because of this uncertainty, we neglect the LREE for the further characterization of the eclogite source, since such percolating mantle metasomatising fluids or melts, which are highly enriched in incompatible elements (even if the agent has very small mass) may change the trace element
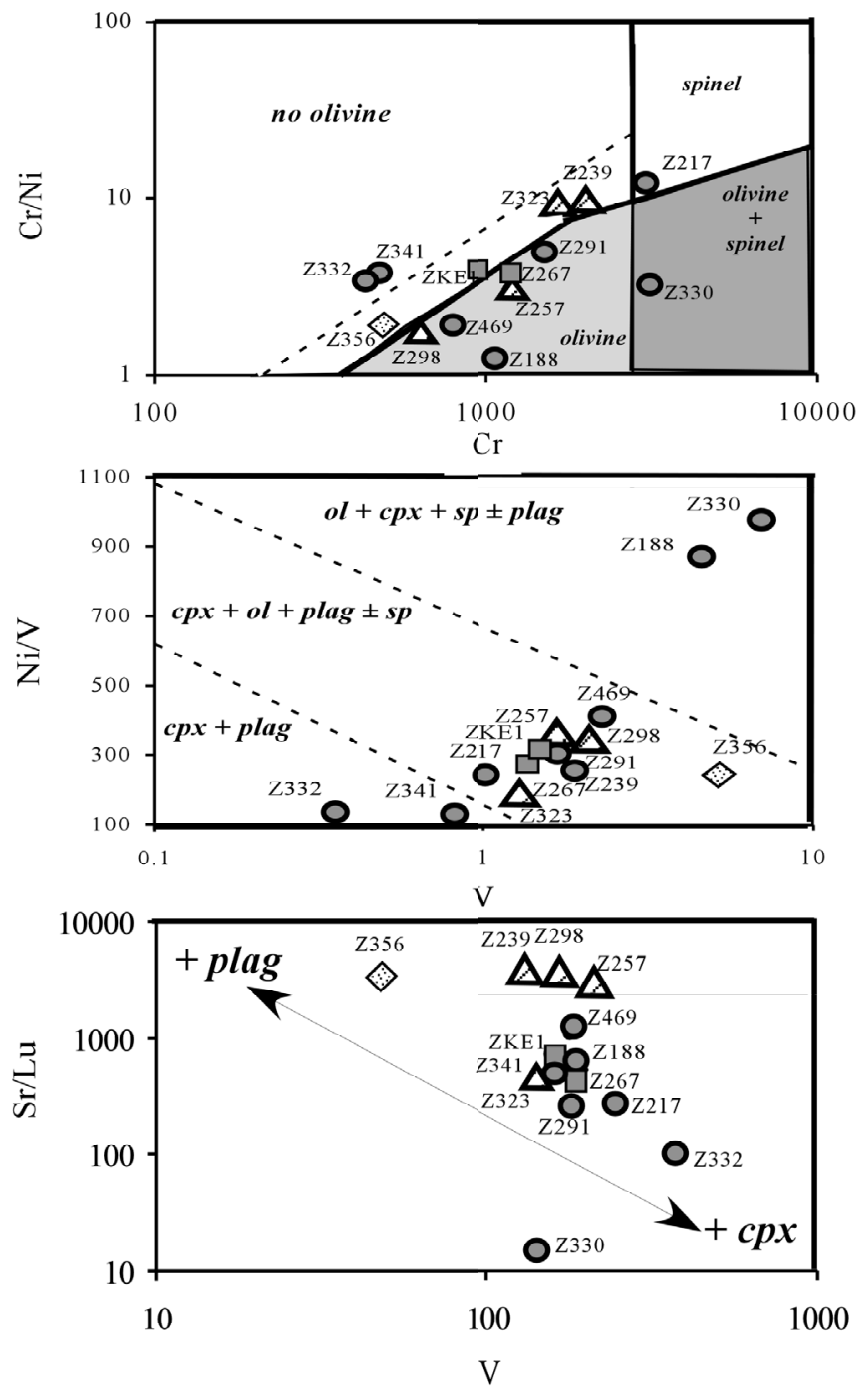

Fig. 9 The ratio of $\mathrm{Cr} / \mathrm{Ni}$ versus $\mathrm{Cr}$ (top), $\mathrm{Ni} / \mathrm{V}$ versus $\mathrm{V}$ (middle) and $\mathrm{Sr} / \mathrm{Lu}$ versus $\mathrm{V}$ (bottom). Samples Z330 and Z217 show the highest $\mathrm{Cr}$ contents, $\mathrm{Z330}$ has also high Ni contents. Compatible elements enriched in Ni (>300ppm) indicate primary olivine and enriched $\mathrm{Cr}(>3000 \mathrm{ppm})$ indicate Cr-spinel in the source. V is highly compatible in cpx and high Sr/HREE ratios might imply plagioclase as an assemblage of the precursory phase. Plotting compatible elements with Sr and HREE, it becomes obvious that the source of the eclogites was composed of olivine, cpx, plagioclase and spinel in different amounts, what implies a slight fractionation trend, not strictly dominated by plagioclase. 
chemistry of mantle rocks severely. Therefore, we focused mainly on HFSE, less compatible MREE and HREE abundances, which vary less between the most depleted bimineralic samples Z239, Z257, Z298 and the orthopyroxene bearing eclogites Z469, Z330 and on compatible elements.

The compatible elements including V, Cr, Mn, Co and $\mathrm{Ni}$ are useful tracers indicating the precursory phases of the eclogites. In particular $\mathrm{Ni}$ and $\mathrm{Cr}$ are indicative elements for the former presence of olivine and spinel in the protolith. Most eclogites have generally low to moderate Cr contents (400 to $1800 \mathrm{ppm}$ ) except samples Z330 and Z217 (>3100 ppm), which argue for the presence of small amounts of Cr-bearing Al-spinel in the protolith. Since mantle peridotite has essentially constant high $\mathrm{Ni}$ contents $(2900 \pm 360 \mathrm{ppm})$, a primary mantle melt saturated in olivine should have at least 300 ppm Ni. The variable Ni contents are in most eclogites rather low (130-415 ppm), corresponding to a fractionated composition and thus the accumulation of olivine in the protolith has to be ruled out for most eclogites. In contrast, the orthopyroxene bearing samples Z330 and Z188 show 976-874 ppm Ni, supporting the presence of primary olivine in the protolith. Hence, the deviation of $\mathrm{Ni}$ and $\mathrm{Cr}$ in the eclogites might be due to progressive crystal fractionation of the eclogite protolith. The resulting trend on the plot $\mathrm{Cr} / \mathrm{Ni}$ vs. $\mathrm{Cr}$ and $\mathrm{Cr} / \mathrm{Sr}$ vs. $\mathrm{Cr} / \mathrm{Al}$ might be related to the combined fractionation of olivine and spinel, which are liquidus minerals in picritic melts (Eggins, 1993), and plagioclase. Based on the composition of compatible elements combined with Sr, various constituents can be inferred for the eclogite protolith.

\begin{tabular}{|l|c|c|c|c|}
\hline \multicolumn{1}{|c|}{ sample } & olivine & plagioclase & clinopyroxene & spinel \\
\hline Z356 & ol & plag & cpx & \\
\hline $\begin{array}{l}\text { Z298, Z257, Z188, } \\
\text { Z469, Z291 }\end{array}$ & ol & plag & cpx & $\pm \mathrm{sp}$ \\
\hline ZKE1, Z267 & $\pm \mathrm{ol}$ & $\mathrm{cpx}$ & $\mathrm{sp}$ \\
\hline Z330, Z217 & $\mathrm{ol}$ & plag & $\mathrm{cpx}$ & $\pm \mathrm{sp}$ \\
\hline Z239, Z323 & & plag & $\mathrm{cpx}$ & \\
\hline Z332, Z341 & & plag & & \\
\hline
\end{tabular}

Table 5

Presumed constituents of the Zero eclogite protoliths indicated by compatible elements.

\subsection{The origin of Zero eclogites evidenced by trace elements}

If, similar to the Zero eclogites, the low pressure derivation for a eclogite xenolith suite can not be approved by a range in $\delta^{18} \mathrm{O}$ values, it has often been interpreted to provide evidence for the "mantle hypothesis", which explains garnet and clinopyroxene as having crystallized from a peridotite melt at high-pressure. According to this "mantle hypothesis" eclogite-producing peridotite melting must have occurred at pressures exceeding $3.5 \mathrm{GPa}$, since most eclogite xenoliths from different kimberlites equilibrated above that depth within the diamond stability field. Although high-pressure experiments proved that eclogite compositions could have been generated from partial melts of peridotite (Takahashi, 1986), a peridotite melt generated at pressures above $3.5 \mathrm{GPa}$ would not lead to basalt but involve a picrite or komatiite composition (Falloon et al., 1988, Kushiro, 1996). Such high-pressure generated melts become increasingly MgO rich with increasing pressure, whereas basalts form at pressure conditions less than $3 \mathrm{GPa}$. This melt would crystallize into an olivinebearing assemblage but not into clinopyroxene and garnet. Olivine-free bimineralic eclogites can not be generated by further fractional crystallization of garnet lherzolite melts. The solidus melting reaction (ol, gt and cpx $\rightarrow$ melt) of a garnet Lherzolite source at pressures exceeding $3.3 \mathrm{GPa}$ is eutectic but shifts to the peritectic reaction: ol $+\mathrm{cpx}+\mathrm{gt} \rightarrow \mathrm{opx}+\mathrm{melt}$ 
with increasing melting (Walter, 1998). At higher degrees of partial melting peritectic reaction and fractional crystallization result into a more evolved melt composition by crystallization of olivine, garnet and cpx and with further cooling into cpx and spinel (Milholland and Presnall, 1998). Therefore, no convincing petrogenetic model for these kinds of "mantle eclogite" has been offered so far and their origin is still enigmatic.

However, some facts about the Zero eclogites other than the oxygen isotopes are evidence in support for direct mantle derivation, including the mafic compositions and relatively low jadeite contents compared to different eclogite xenolith suites. Further supporting arguments are the exsolved minerals, which may be used to argue for a plutonic igneous crystallization at high temperature followed by sub-solidus exsolution. Similar exsolutions are due to the unmixing of clinopyroxene at lower temperatures (Frey, 1980), and are typical for pyroxenites and occurred in response to changing $\mathrm{P} / \mathrm{T}$ conditions. Since orthopyroxene and garnet exsolved in association from clinopyroxene, this might imply high temperature processes, an igneous fractionation might be indicated, although similar exsolutions could also result from adiabatic ascent of the eclogites.

\section{High-pressure derivation}

Nevertheless, the very low REE abundance of the eclogites requires a depleted asthenospheric source and hence argues for the mantle derivation. Even if no evidence is given about the depth, they might be derived. The major element compositions and Mg\# (67-84) of the eclogites need not reflect extrusions or ultramafic magmas formed at high-pressures. However, a pyroxenitic protolith for the eclogites is suggested since the flat REE patterns appears to reflect a pyroxenite formed as igneous cumulates, which fractionated at mantle conditions. Hence the Zero eclogites might in fact represent cumulates which were generated from high pressure $\mathrm{MgO}$-rich picritic or komatiitic melts, produced either as high-pressure (spinel-) garnet-pyroxenites or as low pressure $(<1 \mathrm{GPa})$ plagioclase-pyroxene-olivine cumulates. In order to prove that Zero eclogites might be produced from igneous fractionation processes at high- or low-pressure different approaches were used. As conceivable coexisting melt composition for the eclogites potential constituents with matching Mg\# were selected from layered intrusions (Shaw, 1997). Major element compositions of these minerals were mixed by chemical mass balance and protolith mineralogy. Olivine and plagioclase or olivine, plagioclase and clinopyroxene was used as conceivable cumulate assemblages representative for fractionation at low pressure whereas a plagioclase free assemblage consisting of orthopyroxene, spinel and clinopyroxene was used as a cumulate composition fractionated at high-pressure. Olivine and plagioclase or olivine, plagioclase and clinopyroxene was used as conceivable melt assemblages representative for fractionation at low pressure whereas a plagioclase free assemblage consisting of orthopyroxene, spinel and clinopyroxene was used as a cumulate composition fractionated at high-pressure.

The best matching results for most eclogites corresponded to a composition of forsterite-rich olivine, anorthite plagioclase and diopside clinopyroxene in different modal proportions. Nevertheless, the best fit for most bimineralic eclogites (Z257, Z298, Z239) consisted of omphacitic clinopyroxene, orthopyroxene, plagioclase and spinel, or clinopyroxene, olivine, plagioclase, and spinel. The modal proportion for clinopyroxene lies in the range of 65 to $30 \mathrm{mod} \%$ whereas olivine varies from 41 to $4 \bmod \%$. Anorthite content of most eclogites is $24 \bmod \%$ in average but varies from 53 to $8 \bmod \%$. In samples Z330, Z469, Z217, Z332, Z257, Z298 and ZKE1 the replacement of plagioclase is likely by $4-10 \mathrm{mod} \%$ spinel combined with $25-42 \bmod \%$ enstatite, which is required to balance the low silica content of the $\mathrm{Al}_{2} \mathrm{O}_{3}$ rich omphacite. The results imply the involvement of plagioclase as the main $\mathrm{Na}_{2} \mathrm{O}$ and $\mathrm{Al}_{2} \mathrm{O}_{3}$ bearing phase that leads to a jadeite rich eclogitic composition. However, if most eclogites contained plagioclase, like proposed from the latter approach, there remains the question if positive Eu-anomalies should be recognizable in the REE patterns, since under typical natural conditions $\mathrm{Eu}$ is predominantly divalent, which is more compatible in plagioclase than Eu ${ }^{3+}$ (Drake and Weill, 1972; Drake 
and Weill, 1975). However, since Eu anomalies do not occur in most trace element patterns, remains the question how much plagioclase might have been involved without a positive Eu anomaly appearing in the REE patterns (Fig. 10).

Focusing on this question, trace element patterns were reconstructed using partition coefficients for the potential sources for comparison with the measured trace element pattern of the eclogites. Since the reconstructed element pattern is based only on mineral partition coefficients from experiments on basaltic compositions (Beattie, 1993; 1994; Bindeman, 1998; Fujimaki et al., 1984; Paster et al., 1974) they are thus comparable in element ratios but not in abundance. Nevertheless, the extent of the Eu-anomaly in a plagioclase bearing cumulate is dependent on the REE partition coefficients of the phases involved. The positive anomaly appears quickly if plagioclase is associated with olivine, whereas in a composition with clinopyroxene with or without spinel, the anomaly appears rather low (Fig. 10). Hence, it is evident that small amounts of plagioclase associated with more than 50 $\mathrm{wt} \%$ clinopyroxene might have been present in a pyroxenite source resulting in a pattern that is not compellingly

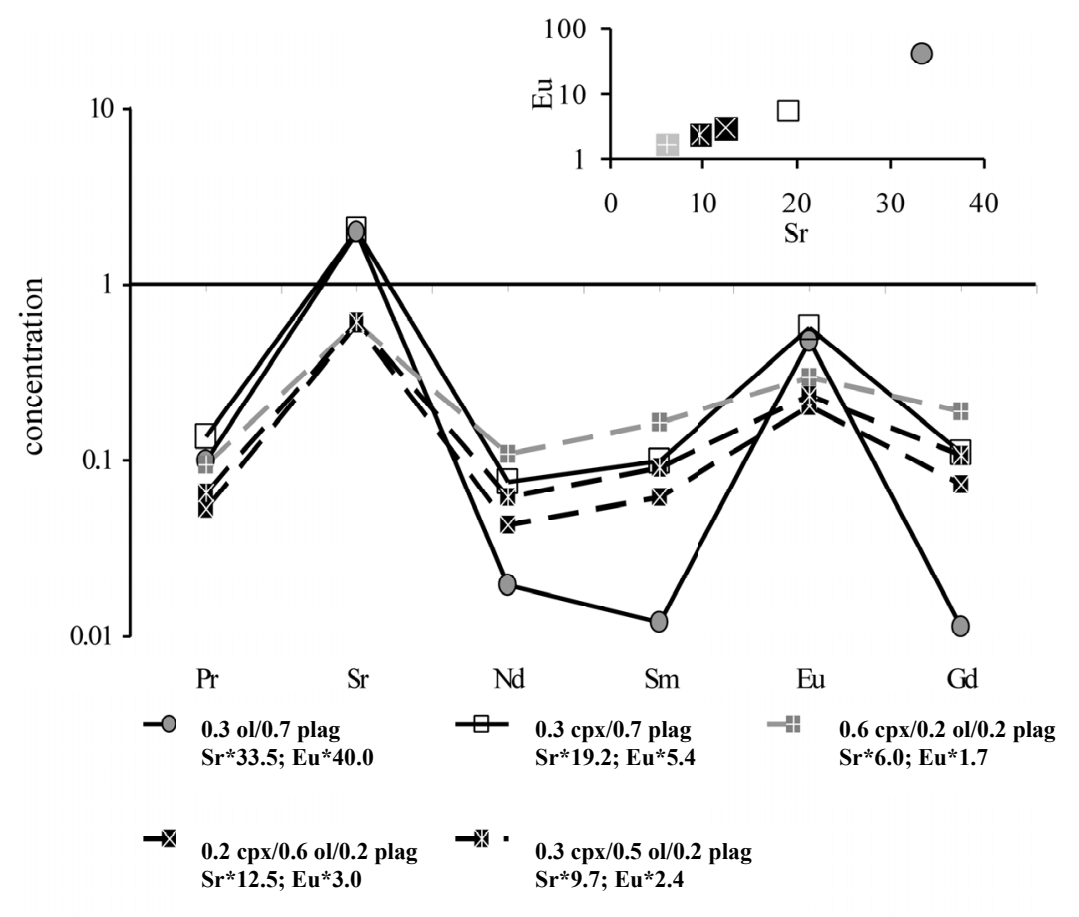

Fig. $10 \quad$ Element pattern of selected traces and Sr versus Eu plot (top right). Various $\mathrm{Sr}$ and Eu anomalies occur in trace element patterns reconstructed by using partition coefficients from experimental approaches for basalt (Beattie, 1993; 1994; Bindeman, 1998; Fujimaki et al., 1984; and Paster et al., 1974) with changing modalities for cpx, olivine and plagioclase. The extent of the anomalies is strongly dependent on the difference between the partition coefficients for the minerals and thus on the composition. In a composition with $60 \mathrm{wt} \%$ cpx and 20 $w t \%$ olivine, the presence of $20 \mathrm{wt} \%$ plagioclase yield just to an Eu anomaly of 1.7, which can easily be overlooked in the REE pattern.

recognizable as a positive Eu-anomaly. Nevertheless, since the partition coefficient for Sr in plagioclase compared to the other phases is 50 times higher, if plagioclase was present in the source in any amount it should be recognizable in a positive Sr anomaly. Nevertheless, this basic approach argues that small amount of plagioclase might have been existed in the source in spite of lacking positive Eu anomalies. Since even small amounts of plagioclase would indicate the lowpressure origin of the eclogites, thus the clear evidence for the presence of plagioclase in the eclogitic protolith is required.

\section{Forward modeling with pMELTS}

To assess possible parental magmas of the Zero eclogites, distinct partial melts of peridotite, including MORB, picrite and komatiite, generated between 1.2 and 3.5 GPa, were used for modeling fractionated crystallization between 1-2GPa with the program pMELTS by using experimental studies of Falloon and Green (1988). PMELTS is the thermodynamic algorithm and revised version of MELTS, which was designed to calculate phase equilibria for partial melts at low pressure, whereas pMELTS is intended to be accurate at high pressures. Although pMELTS was conceived for the calculation of peridotite partial-melting at high pressure we used the inverse mode to produce cumulates in equilibrium with high pressure fractionated melts. Various picritic equilibrium partial melt compositions from MORB pyrolite, which correspond to melt generation at distinct depths, in addition to an average komatiite and a MORB composition were used as parental melts for the accumulation of the eclogites. 
The $\mathrm{MgO}$ rich picrite and komatiite melts, generated at pressures in the range of 1.5 to $3.5 \mathrm{GPa}$, were tested for fractionation at high-and low-pressure. MORB melts, which derived from below $1.2 \mathrm{GPa}$, were fractionated at $1 \mathrm{GPa}$, although the higher pressure cumulate would produce successful matches to the eclogitic composition. According to the inferred crystallization sequences from pMELTS (Fig. 11) the Zero eclogites might be cumulates of rather primitive picritic but not from komatiite melts, which fractionated at pressures not above 1 to $1.5 \mathrm{GPa}$. The resulting chemical composition of the segregated cumulates is controlled by the initial composition and the accumulated liquidus phases, and is further dependent on the pressure conditions and the oxygen fugacity. However, starting from a komatiite melt the liquidus phase at isobaric high-pressure ( $2 \mathrm{GPa})$ is spinel, which is later joined by orthopyroxene and clinopyroxene. Since the high-pressure fractionation lead to $\mathrm{MgO}$-rich but $\mathrm{Al}_{2} \mathrm{O}_{3}$ - and $\mathrm{Na}_{2} \mathrm{O}$-poor composition, the cumulate did not produce successful matches to the eclogite chemistry (Fig. 13). The derivative cumulates segregated from komatiite melt at $1 \mathrm{GPa}$ leads to an assemblage of clinopyroxene and olivine. With decreasing temperature feldspar occurs and the cumulate becomes higher in $\mathrm{Na}_{2} \mathrm{O}$ but $\mathrm{SiO}_{2}, \mathrm{Al}_{2} \mathrm{O}_{3}$ and $\mathrm{MgO}$ contents are distinctly different to the Zero eclogites (Fig. 13). The crystallization sequence of a typical MORB melt composition fractionated at $1 \mathrm{GPa}$ is dominated by the fractionation of olivine. At lower temperatures plagioclase occurs and the $\mathrm{Mg} \#$ of the cumulate produced decreases rapidly, while the $\mathrm{SiO}_{2}$ content increases, again in contrast to the Zero eclogites. The fractionation of primitive MORB melt at higher pressures is useless, since such a MORB composition derives from pressure conditions below $1 \mathrm{GPa}$, though the cumulate would lead to the best matching composition to the eclogites, since Tschermak's rich clinopyroxene occur with garnet.
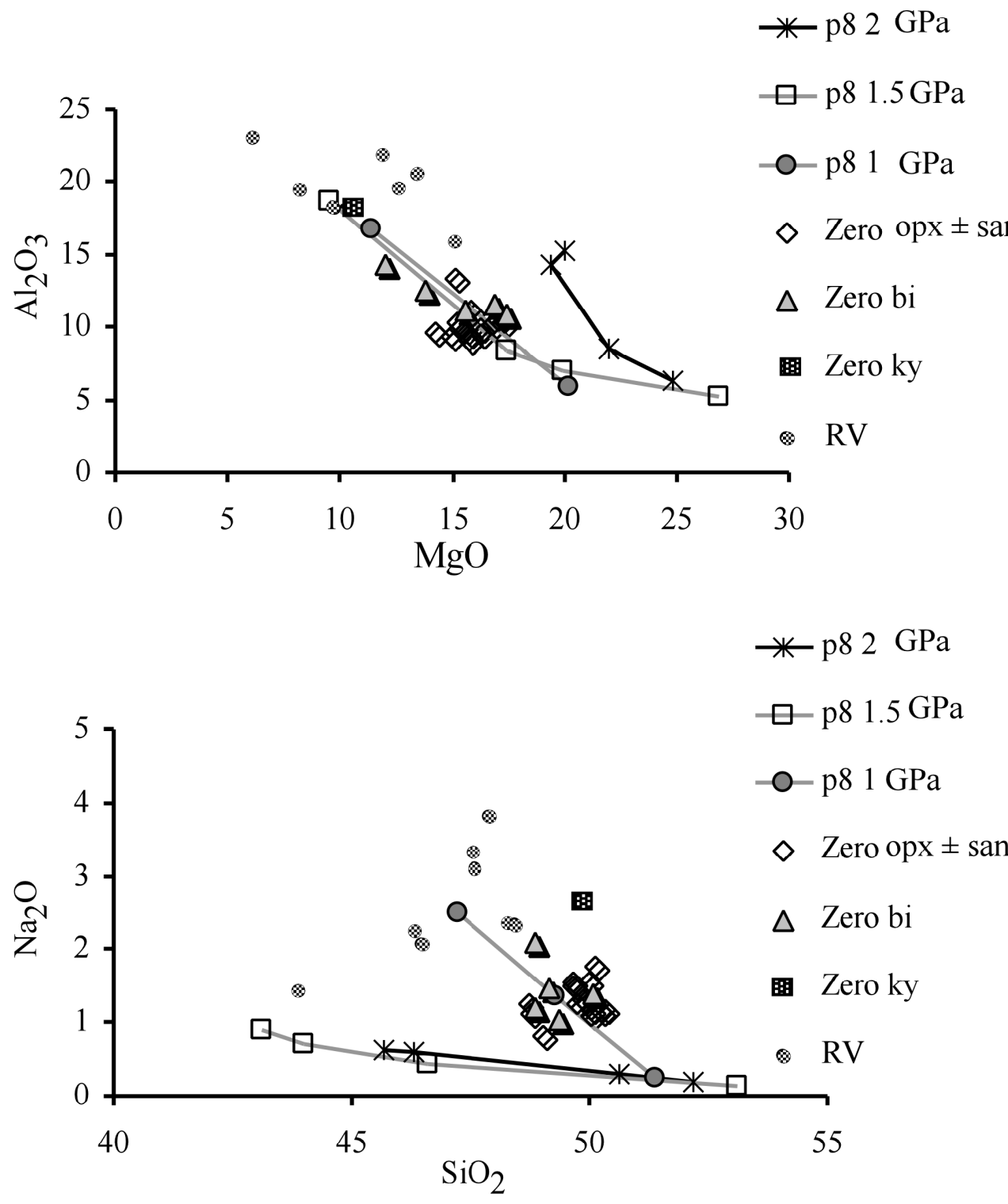

Fig. 11 $\mathrm{Al}_{2} \mathrm{O}_{3} / \mathrm{MgO}$ and $\mathrm{Na}_{2} \mathrm{O} / \mathrm{SiO}_{2}$ ratios of modeled cumulates produced from a picrite melt generated at $\quad 1.8 \quad \mathrm{GPa}$, fractionated at $1 G P a$ 1,5 GPa and $2 \mathrm{GPa}$. The cumulates fractionated at 1-1.5 GPa show the best matching composition to Zero eclogites. Cumulates fractionated at higher pressures (2 GPa) result into lower $\mathrm{Na}_{2} \mathrm{O}$ content and higher $\mathrm{MgO}$ composition distinct from the Zero eclogite. Significantly, Roberts Victor eclogites, which represent typical plagioclase cumulates follow the trend and fall into the line with the Zero eclogites. 
However, high-pressure derived melts are rather enriched in $\mathrm{MgO}$ and $\mathrm{Al}_{2} \mathrm{O}_{3}$ and the crystallization sequences inferred from different melts at $1 \mathrm{GPa}$ are either expressed by the fractionation of olivine plus spinel or spinel plus clinopyroxene due to the $\mathrm{MgO} / \mathrm{Al}_{2} \mathrm{O}_{3}$ ratio. Furthermore the initial $\mathrm{Na}_{2} \mathrm{O}$ content appears to be crucial for the ensuing cumulate at high and low pressures since the occurrence of anorthite at low pressures and the Al-content or tschermaks component of clinopyroxene at high pressure is controlled by the $\mathrm{Na}_{2} \mathrm{O}$ content. Hence, clinopyroxene crystallized at high pressure contain increasing jadeite but decreasing $\mathrm{SiO}_{2}$ content, which is caused by the substitution of $\mathrm{SiO}_{2}$ and $\mathrm{CaO}$ by $\mathrm{Al}_{2} \mathrm{O}_{3}$ and $\mathrm{Na}_{2} \mathrm{O}$. Hence, the evolving plagioclase free high pressure cumulate is similar in $\mathrm{Na}_{2} \mathrm{O}$ and $\mathrm{Al}_{2} \mathrm{O}_{3}$ contents but the low $\mathrm{SiO}_{2}$ content of the cumulate does not produce successful matching to the eclogites.

\section{Inferred consequences for the petrogenesis of the Zero eclogites:}

That the Zero eclogites can not be derived from monomineralic high pressure cumulates is evidenced by the maximum $\mathrm{Na}_{2} \mathrm{O}$ content of $0.7 \mathrm{wt} \%$ with $50 \mathrm{wt} \% \mathrm{SiO}_{2}$ of clinopyroxene, which was produced as liquidus phase at highpressure: higher jadeite contents in omphacites are associated with lower $\mathrm{SiO}_{2}$ contents as expected for eclogites. The highest $\mathrm{Na}_{2} \mathrm{O}$ content of $1.47 \mathrm{wt} \%$ in a plagioclase-free cumulate consists of clinopyroxene and spinel, and occurs with the lowest $\mathrm{SiO}_{2}$ content of $42 \mathrm{wt} \%$, indicating that plagioclase is required for the crystallization of an eclogitic composition. Nevertheless, in cumulates segregated at high pressure as well as in $\mathrm{Al}_{2} \mathrm{O}_{3}$ rich magmas, which crystallized at lower pressures the liquidus phase is always spinel prior to clinopyroxene. Consequently, the main constituent cumulus phase of the eclogites was $\mathrm{MgO}$ rich clinopyroxene, but spinel and feldspar should have been present as minor assemblages within the precursory cumulate as well. The latter results point out that the protolith of the eclogites cannot represent a cumulate crystallised at higher pressure than $1.5 \mathrm{GPa}$.

The best matching cumulates for the eclogite composition derived from picritic magma generated at $1.8 \mathrm{GPa}$ and fractionated at $1 \mathrm{GPa}$ (Fig. 12a-e). The resulting cumulate, which at first consists of MgO-rich clinopyroxene and small amount of spinel before plagioclase occurs, correlates best to the bulk composition of the orthopyroxene bearing Zero eclogites. With decreasing temperature, the cumulate develops towards the composition of the bimineralic eclogites. Furthermore, the crystallization of different melts between 1 - 1.5 GPa show that the accumulated sequences can differ from monomineralic MgO-rich clinopyroxene with adjacent spinel into the assemblages clinopyroxene, spinel and plagioclase. The crystallization of magmas higher in $\mathrm{MgO}$ initiate with olivine or spinel with adjacent clinopyroxene. However, with decreasing temperature cumulates occur which either consist of olivine and spinel with feldspar or spinel and clinopyroxene with feldspar.

According to the latter fractionation trends at different pressures, the Zero eclogites might be derived from mainly MgO-rich clinopyroxenites with primary spinel and a minor amount of olivine and feldspar crystallized at pressures between 1-1.5 GPa. Hence, in contrast to eclogites xenoliths derived from gabbros or volcanic parts of the oceanic crust, the Zero eclogite suite corresponds to a crystallization sequence at that pressure. The more mafic parts at the base of the sequence thus consisted of spinel, $\mathrm{MgO}$-rich clinopyroxene with a small amount of plagioclase evolving into lower $\mathrm{MgO}$ rich parts, represented by increasing amounts of plagioclase and spinel or olivine. The MgO-rich base of the sequence might be represented by the orthopyroxene bearing eclogites like Z330 and Z469, which consisted of MgO rich clinopyroxene with distinct amounts of orthopyroxene, spinel, primary olivine and less plagioclase. This assumption is consistent with the occurrence of flat and depleted REE trace element patterns and further suggested by higher $\mathrm{Cr}$ (Cr-bearing spinel) and in particular higher Ni values, which are indicative for primary olivine. Those basal cumulates were metasomatised by pervading fluids, which produced vein assemblages consisting of clinopyroxene and hydrous minerals like phlogopite 
similar to ZKE1 and Z267. Further disperse reaction produced metasomatised cumulates with different chemical composition similar to Z291, Z332, Z188, Z341 and Z217.

At shallower levels bimineralic eclogites occur, which consisted of clinopyroxene with olivine or spinel and a higher amount of plagioclase (19-43 wt \%). Since plagioclase has the highest partition coefficients for LREE and the lowest for HREE, the bimineralic eclogites are more depleted in HREEs but show higher $\mathrm{La} / \mathrm{Lu}$ ratios than the other eclogites. The plagioclase rich sample Z323 (43 wt \%) might be the top of the sequence of the bimineralic eclogites, which is in good agreement with their slight positive Eu anomaly and the lowest REE abundances. That the shallower levels were affected by metasomatism as well is reflected by the cryptic metasomatism of the bimineralic eclogites.

The kyanite eclogite apparently represents the uppermost level of the fractionated cumulates and consisted apparently (according to Igpet) of $60 \mathrm{wt} \%$ plagioclase, $31 \mathrm{wt} \%$ clinopyroxene and $9 \mathrm{wt} \%$ spinel, which corresponds to the lowest REE abundance compared to the other eclogites. However, the unusual mineralogical and textural inventory of the kyanite bearing eclogites is unique and requires a genesis at changed P-T conditions, since the crystallization of the kyanite laths with cpx indicate a stage prior to the sub-solidus exsolution of garnet and kyanite from cpx. The occurrence of the kyanite laths associated with omphacite was formed during the metamorphic reaction:

$$
\begin{gathered}
\text { albite }+ \text { anorthite }+ \text { spinel } \rightarrow \text { jadeite }+ \text { Ca-Tschermak's }+ \text { enstatite }+ \text { kyanite } \\
\mathrm{NaAlSi}_{3} \mathrm{O}_{8}+\mathrm{CaAl}_{2} \mathrm{Si}_{2} \mathrm{O}_{8}+\mathrm{MgAl}_{2} \mathrm{O}_{4} \rightarrow \mathrm{NaAlSi}_{2} \mathrm{O}_{6}+\mathrm{CaAl}_{2} \mathrm{SiO}_{6}+\mathrm{MgSiO}_{3}+\mathrm{Al}_{2} \mathrm{SiO}_{5}
\end{gathered}
$$

Garnet was apparently exsolved later from Tschermak's component due to unmixing of clinopyroxene caused by cooling or increasing pressure. According to the mass balance reaction, garnet and kyanite could not be produced simultaneously from cpx host, which would argue for the former existence of corundum and garnet within the lamellae. It is likely that kyanite was produced later within the exsolution lamellae by the breakdown of Ca-Eskola molecule into tschermak's componentbearing pyroxene and silica that reacted with corundum to kyanite.
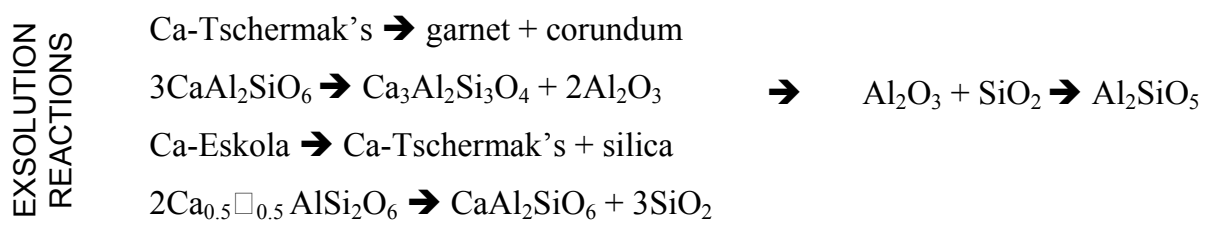

The breakdown of Ca-Eskola clinopyroxene apparently took place during the exhumation, which is argued since the vacancy-containing Eskola component is reported to be pressure sensitive and highly unstable at lower pressure (Mao, 1971; Smyth, 1980; Katayama et al. 2000). If the exsolution of garnet and corundum from Tschermak's component resulted from cooling or was produced by increasing pressure remains speculative. The same applies to the uncommon loss of FeO $(\mathrm{FeO}=1.13 \mathrm{wt} \%)$ which remains unexplained for the moment. However due to the latter reactions we can point out that the kyanite eclogite has experienced a different P-T-t-path similar to the remaining eclogites. That the kyanite eclogite was later affected by metasomatism is evidenced by the occurrence of Ba-bearing sanidine ( $4 \mathrm{wt} \% \mathrm{Ba})$, which was apparently produced by metasomatic Ba-bearing biotite prior to metamorphism. It is likely that the metasomatic event is not attributable to the $\mathrm{H}_{2} \mathrm{O}$-rich kimberlite melt imprint since otherwise the sanidine should have changed to phlogopite.

Summing up the results, the petrogenesis of the Zero eclogites is consistent with crystal accumulation from picritic magmas within the upper mantle at $1-1.5 \mathrm{GPa}$, prior to metamorphism. It is likely that the eclogites are genetically related pyroxenites, which show slight distinct compositions, caused by the fractionation of the parental magmas. However that the eclogites deviate slightly from the ideal fractionation trend of the crystal segregation shown in Fig. 11a-e is reasonable since 
the starting material, which was taken from experimental approaches does not claim to be the perfect source. Presumably, the parental magma was however a mixture of melts, which generated and fractionated at different depth. Subsequently metasomatism, wall rock reaction, exsolution, metamorphism and partial melting are reasonable processes, which might have changed the eclogites later from the initial composition. Nevertheless, at least the chemical inconsistency of the kyanite eclogites might indicate that partial melting could have been a late stage process of the eclogites petrogenesis.

Considering the crystallization sequences and the thermobarometry it is evident that the eclogites formed at shallower depth than their re-equilibration took place (Schmickler et al., 2002) and thus the suite must have been carried into greater depth previously, what further cites in support of their genetic relation. The reconstruction of the eclogite history is helped especially by the sanidine eclogites. In our preliminary study we have argued that those eclogites represent pyroxenite vein assemblages, which consisted mainly of phlogopite and clinopyroxene. This assumption is supported by the trace element abundance from the present study. Petrographical evidence attributed the source of the metasomatising solution not to the kimberlite itself. Fortunately, the metasomatising fluid intruded into the cumulate suite and witnesses the geodynamic process which carried the rocks into greater depth, prior to re-equilibration conditions at shallower depths, documented by exchange mineral reactions at 3.5-4 GPa. However, since those veins might be derived from (i) the asthenosphere, (ii) evolved from a melted or dehydrating down-going slab pervading the sub-continental lithosphere, or (iii) deeper levels of oceanic crust the occurrence of similar pyroxenite veins cannot effectively distinguish the environment of the eclogite protoliths. However, pyroxenite mantle-vein assemblages might occur anywhere within the sub-crustal lithosphere and thus different settings might be possible. Near solidus experiments at mantle pressure showed that mafic and ultra-mafic mantle veins consisting of assemblages rich in clinopyroxene and hydrous minerals may be relevant sources for various continental alkaline magmas (Foley, 1992, Foley et al., 1999). Considering the sanidine eclogites, it appears that similar metasomatic veins might accidentally occur as the source for at least potassium bearing eclogites. Similar subduction of K-cpx-rich rocks, which formed through the percolation of K-rich fluids within eclogitic bodies was suggested for the sanidine bearing eclogites from the Kokchetav massif (Kazakhstan; Sobolev and Shatsky, 1990). The subduction of such fluids is proposed to recycle supra-crustal $\mathrm{K}, \mathrm{Rb}, \mathrm{Cs}, \mathrm{Pb}, \mathrm{Sr}$, and $\mathrm{Nd}$ to the mantle, up to the majorite stability.

Due to the low trace element abundance a vein assemblage phlogopite and Ca-tschermaks rich clinopyroxene without amphibole appears most appropriate as protolith for the sanidine eclogites. For the source of those opx-bearing eclogites showing quartz inclusions in garnets but occur without sanidine (Z175, Z330) a vein assemblage with Ca-tschermaks rich clinopyroxene and added K-richerite (which later decomposed to Ca-pyroxene and ortho-enstatite), might be possible. If those depleted veins were produced from a fluid or melt of a previously depleted source like an oceanic slab or derived from a primitive mantle source remains however speculation. Far from a speculation is that the eclogites were carried to greater depths, which is witnessed by the sanidine eclogites. That the protolith passed beyond the phlogopite stability field into higher $\mathrm{P} / \mathrm{T}$-conditions is evidenced by the eclogitic textures and the previous $\mathrm{K}_{2} \mathrm{O}$-content of the clinopyroxenes prior to the sanidine exsolution. Considering the abundant data from experiments enforced on phlogopite, the phase relations and inferred decomposition curve is strongly dependant on the phlogopite composition. Whereas in the high pressure experiments on a pure end member system phlogopite breaks down to pyrope and forsterite (Tronnes, 2000) at $8 \mathrm{GPa}$, natural phlogopite decomposes previously at pressures of 5-8 $\mathrm{GPa}$ and temperatures at $1200-1300^{\circ} \mathrm{C}$ continuously to pyrope and fluid (Sato et al., 1997).

With preceding reaction, the amount of pyrope increased with pressure, which is reflected in a systematic change of the decomposing phlogopite composition. At $8 \mathrm{GPa}$, free fluid was recognized in the experiments (Sato et al., 1997), which was released through the dehydration reaction of phlogopite and dissolved lithophile elements including $\mathrm{K}^{+}, \mathrm{Rb}^{2+}, \mathrm{Cs}^{2+}$ and 
$\mathrm{Si}^{4+}$ expelled from phlogopite. From experimental studies on the phlogopite-pyroxene phase relationships (Luth, et al. 1997; Harlow, 1999, Sudo and Tatsumi, 1990, Tronnes, 1990) we know that with preceding pressure and temperature at that depth, the incorporation of $\mathrm{K}_{2} \mathrm{O}$ into clinopyroxene was possible. According to the experiments, the $\mathrm{K}$ substituting into the pyroxene structure is a coupled substitution with $\mathrm{Al}$ as a jadeite like $\mathrm{KALSi}_{2} \mathrm{O}_{6}$ component. The comparison of the experimental data illustrate that the coexisting phase assemblages and the K-content of the coexisting phases control the incorporation of $\mathrm{K}_{2} \mathrm{O}$ in cpx.

The dehydration process of phlogopite might explain the formation of the typical textures (garnet domains form a foliation) and the inclusions within the garnet cores. Possibly the released fluid, saturated in lithophile elements, was entrapped as fluid inclusions within the garnets and might be incorporated into the garnet structure (Lu and Keppler 1997). Subsequently, coesite, rutile and K-feldspar might have crystallized from the potassium and silica saturated fluid at highpressure. If so, decreasing pressure might have caused the decrepitation and leakage of the fluid inclusions within the primary euhedral garnets (or was incorporated into the garnets), which left the quartz, rutile and sanidine crystals behind. Nevertheless, the crystallization from a fluid might explain why rutile and quartz inclusions are rimmed by tiny inclusions, possibly fluids. However, due to the lack of experiments for the time being the latter explanation has to remain speculative.

\subsection{Models for the formation of the Zero eclogites}

That the eclogitic protoliths derived from cumulates, which were partly pervaded by metasomatic veins appears to be evident, but the question remains from which lithologic unit they might be derived. Similar cumulate sequences might occur at the base of an oceanic lithosphere or within magma chambers of the sub-continental lithosphere. Alternatively similar mafic and ultra-mafic pyroxenites might have formed as igneous crystal deposits within dykes or channels in the upper mantle as a result of magmas ascending through the mantle. That the presence and fractionation of plagioclase is constrained for the eclogitic source might support that the magma evolved in a magma chamber, though fractionation processes might also take place dynamically within veins or dykes. Nevertheless, similar variation of compatible elements observed in the eclogites might also occur at the base of the lower mafic part of an ophiolite sequence or alternatively in the outer parts of the dykes where wall rock reaction occurs. However trace element data on pyroxenite xenoliths from subcontinental mantle beneath Vitim volcanic field (Litasov et al., 2000) show that vein pyroxenites occur with different chemical compositions but should be at least more enriched in REE compared to the eclogites since they form from small, highly REE-enriched masses. Hence, the low trace element abundance of the eclogites contrasts the origin as dyke or vein assemblage for the bimineralic eclogites. Nevertheless, the low trace element abundance is reminiscent of a cumulate sequence from a mid ocean ridge basin in which olivine, clinopyroxene and plagioclase dominate the assemblages. Cumulate rocks exposed in ophiolite sections include dunites, peridotites and chromites in layers of $\mathrm{cm}$ in size whereas several meters of magnesian clinopyroxenes, orthopyroxenes including pyroxenites and gabbros occur, which contain more than $10 \%$ plagioclase. Since the stratigraphically lowest levels of ophiolites occur in such a low abundance it appears statistically reasonable that dunites and chromites should occur only rarely as xenoliths. Furthermore, since the Zero eclogites were carried into depths of 180-240 km depth $(6-8 \mathrm{GPa})$, one might argue for the formation of the pyroxenite sequence at the base of a slab later subducted.

Nevertheless, the fact that the cumulates crystallized at $1 \mathrm{GPa}$, equivalent to a depth of at least $30 \mathrm{~km}$, appears to contradict a crustal derivation and transfer the eclogite formation into the upper mantle or might occur as the evidence that Achaean oceanic crust was thickened (Storey et al., 1991). It should possibly be taken into account that eclogites could have 
formed as cumulates at the base of an oceanic plateau. Oceanic plateaus, like the Ontong Java Plateau (west central Pacific; e.g Furumoto et al., 1976) are igneous provinces which were formed during an initial plume-head stage of hot-spot development (Richards et al., 1991), and occur with crustal thickness exceeding $30 \mathrm{~km}$. Adjacent magmas are consistent with $20-30 \%$ partial melt of peridotite, generated within the garnet stability field and continuing in the spinel field. Since the parental magmas represent mixed melts and thus the effects of a strong olivine control is lacking occurs in good agreement with the chemical composition of the Zero eclogites, in which no evident fractionation trend is reflected in trace elements. With increasing depth of crystallization, the cumulate is predicted to change from olivine, orthopyroxene gabbro through troctolite and /or leucogabbro to melanogabbro, pyroxenite, or clinopyroxene-norite (Farnetani, 1996).

However, problems are caused since those over-thickened oceanic crust tend to be more buoyant than normal oceanic crust and are explained as rather unsubductible, but have the potential to be obducted onto continental margins. Caused by the identical chemical composition of the sub-crustal lithosphere with the surrounding asthenosphere and the buoyancy effect of a melt depleted mantle root, oceanic crusts thicker than $25 \mathrm{~km}$ should generally not be subductible at least with modern geotherms (Burke and Kidd, 1978; Saunders et al., 1996). However in case crustal thickness is close to $36 \mathrm{~km}$ the basal levels would be in the eclogite stability field (Saunders et al., 1996) and the transformation of lower crust to eclogite could promote subduction of at least the lower portion of the plateau. Furthermore, conversion of lower crust from granulite to eclogite facies would be promoted by small amounts of water or by stress, which could result from the arrival of a plateau at a subduction zone. The addition of fluids escaping off a slab subsequently sinking beneath a plateau and following reversal of subduction direction after collision may promote eclogite formation and cause eventual subduction of at least the lower plateau crust. The fact that the eclogites were metasomatised prior to or during the eclogitisation together with the

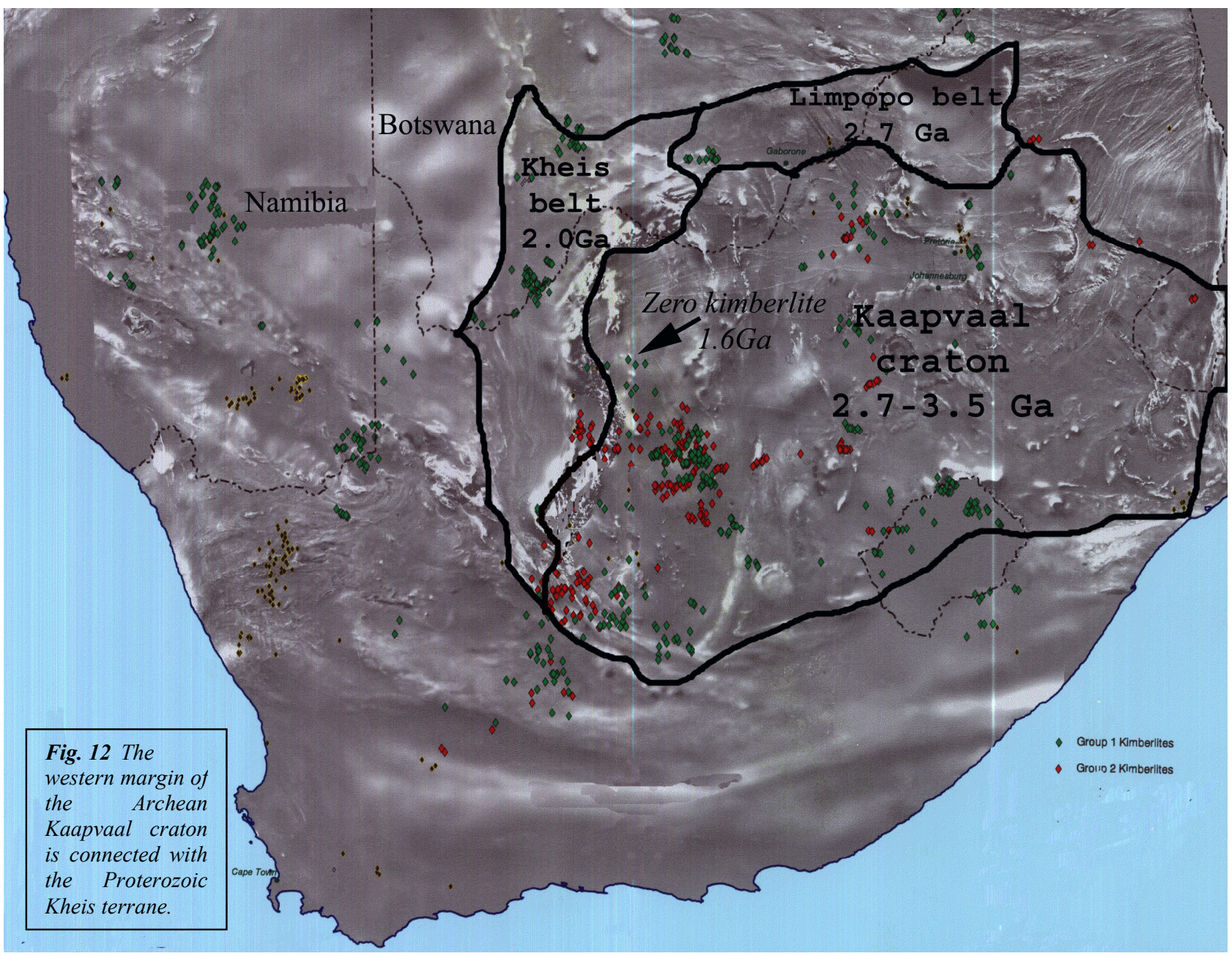


reflected P-T-t-path might occur as evidence for the tectonic situation similar to the collision of an oceanic plateau with the continental crust. Since the plateau itself is unsubductible the resulting stress promoted the subduction of connected thinner oceanic crust beneath the plateau. Fluids of distinct compositions released from the dehydrating slab metasomatised the base of the plateau. Furthermore, the appearance of fluid promoted formation, which caused subduction of at least the lower plateau crust and carried the eclogitic, metasomatized protolith from $30-45 \mathrm{~km}$ into depth of at least $180-240 \mathrm{~km}$ depth.

However, two controversies argue against the latter hypothesis and propose that the eclogites might have formed from underplated magmas crystallized within a sub-continental magma chamber, which correlates as well with crystallization depth and the lack of seawater alteration. First, the geological situation at the western margin of the Kaapvaal craton advocates the collision with a continent since no indication of obducted or accreted oceanic crust occurs and furthermore the existence of oceanic plateaus during Archean times is not established.

\subsection{Geodynamic aspects}

The Kaapval craton, which was probably formed by the accretion of many smaller terranes 3.6 to 2.7 Gyr ago (e.g. de Wit, 1992), is made up largely of Archean tonalitic and trondhjemitic gneisses and granitoids, with lesser volumes of metamorphosed volcano-sedimentary rocks known as greenstone belts. Underplating and igneous intrusions strengthened the craton, which is rimmed by younger mobile belts. According to recent high velocity seismic data, the cratonic root structures are irregular, with evidence for keel depths of at least 250-300 km (James et. al 2001) in the southern part of the Kaapvaal craton. The Namaqua-Natal Metamorphic Province forms an arcuate belt that is draped around the western and southern margins of the Kaapvaal craton. The western craton margin is connected with the Kheis tectonic province which includes a terrane-bounding structure and is composed of highly metamorphosed and strongly deformed rocks considered as a subdivision of the Namaqua Natal metamorphic province (Moen, 1999).

The latter unit of continental crust is defined in terms of its orogenic history and comprise a fold and thrust belt that developed at the western margin of the Kaapvaal craton during the 1.75 Ga Kheis orogeny (Cornell et al., 1992). This northtrending orogenic belt (2.0-1.9 Ga) of the Northern Cape, which is sandwiched between the Namaqua belt and the Kaapvaal craton shows increasing metamorphic grades towards the craton. Apparently, the different stages of eclogite formation are related to special episodes of the southern Kheis belt fringing the eastern margin of the Kaapvaal craton. Considering that the eclogites were overprinted metasomatically prior to subduction, the eclogites presumably formed as underplated magmas beneath the Kheis terrane rather than underneath the Kaapvaal craton. Hence, the later collision between the Kheis terrane and the Kaapvaal craton is feasible as a driving force for the transfer of the eclogite protoliths into minimum transfer depth of 180 $\mathrm{km}$, deduced from the phlogopite break down. Hence, it appears that sub-continental lithosphere can be displaced to at least $150 \mathrm{~km}$ depth by a continental collision. It is likely that isostasy rather than buoyancy was the responsible geo-dynamic process for the subsequent ascent of the eclogitic protoliths from asthenospheric depths to equilibration levels of $100-120 \mathrm{~km}$ constrained by the P-T-t-path of the eclogites. Considering the advanced equilibration state of the eclogites a long period is suggested for the retrograde reaction. The time between the end of the Kheis orogeny at $1750 \mathrm{Ga}$ and kimberlite eruption at $1600 \mathrm{Ga}$ of $150 \mathrm{Ma}$ would be sufficient to erode $70 \mathrm{~km}$ overlying crust (with an erosion rate of $0.04-0.09 \mathrm{~cm} / \mathrm{a}$ ).

Hence, the off-cratonic genesis for the eclogites outlined above (Fig. 12), which would be consistent with the higher geothermal gradient indicated by the eclogites and definitely the lack of diamonds (or graphite), argues that the Zero eclogites should not be older than the Kheis belt, which is about 2 Ga years. 
Accretion of the Paleoproterozoic Kheis belt towards the Kaapvaal craton

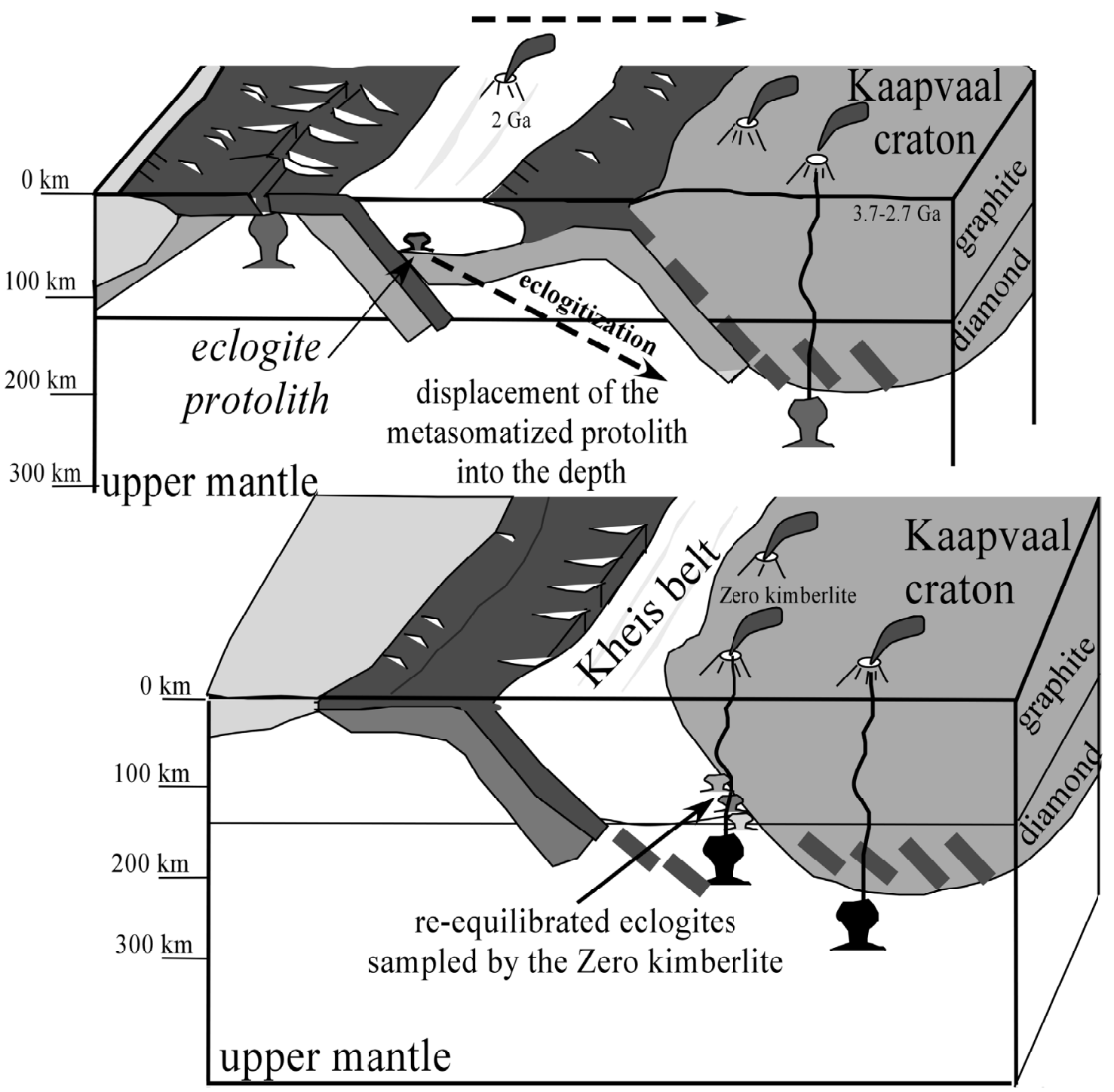

Fig. 13 The sketch gives an idea about the protolith formation of the Zero eclogite suite and show a tectonic model for the W-margin of the Kaapvaal craton. According to major and trace element chemistry combined with source modeling with p-Melts, the protoliths of the eclogites formed not deeper than about 1 to $1.5 \mathrm{GPa}$. Inferred from thermobarometry, the eclogites have been brought to greater depth about 6-8 GPa, previously, apparently during the collision between the Kheis belt and the Kaapvaal craton during the Kheis orogeny $1.7 \mathrm{Ga}$ ago. If the protolith of the eclogites derived from a molten slab or an underplated magma remains unexplained. Notice, clear indication for an island arc- or rift volcanism is lacking or not outcropped on the Kheis belt however, the sinking of the eclogites protolith proof that during a continent collision, subcontinental lithosphere can be displaced for $150 \mathrm{~km}$ into the deep.

\section{References}

Barth, M., Rudnick, R.L., Horn, I., McDonough, W.F., Spicuzza, M., Valley, J.W. and Haggerty, S.E., 2001. Geochemistry of xenolithic eclogites from West Africa, part I: A link between low MgO eclogites and Archean crust formation. Geochim. Cosmochim. Acta, 65: 1499-1527.

Barth M., Rudnick R. L., Horn I., McDonough W. F., Spicuzza M., Valley J. W., and Haggerty S. E., 2002 Geochemistry of xenolithic eclogites from West Africa, part II: Origins of the high MgO eclogites. Geochim. Cosmochim. Acta in press. 
Beattie, P., 1993. Trace element partitioning between silicate melts and olivines and orthopyroxenes. Geochim. Cosmochim. Acta, submitted.

Beattie, P., 1994. Systematics and energetics of trace-element partitioning between olivine and silicate melts: Implications for the nature of mineral/melt partitioning. Chem. Geol., 117: 57-71.

Bindeman I. N., Davis A. M., and Drake M. J., 1998. Ion microprobe study of plagioclase-basalt partition experiments at natural concentration levels of trace elements. Geochim. Cosmochim. Acta 62, 1175-1194.

Blundy, J. and Wood, B., 1994. Prediction of crystal-melt partition coefficients from elastic moduli. Nature, 372: $452-454$.

Burke, K. and Kidd, W., 1978. Were Archean continental geothermal gradients much steeper than those of today? Nature, 272: 23-24.

Cornell, D., Kröner, A., Humphreys, H. and Griffin, G., 1992. A collision related pressure-temperature-time path for Prieska Copper Mine, Namaqua-Natal Province, determined by single grain zirkon $\mathrm{Pb}-\mathrm{Pb}$ dating. Precambrian Res., 59: 4371.

Dawson, J. B., 1984. Contrasting types of upper-mantle metasomatism? Kimberlites II: The mantle and crust-mantle relationships. J. Kornprobst. Amsterdam, Elsevier. 2: 289-294.

de Wit, M. J., C. Roering, et al., 1992. "Formation of an Archaean continent." Nature 357: 553-562.

Drake, M. and Weill, D., 1972. The distribution of Sr, Ba, Eu2+, Eu3+ and other REE between plagioclase feldspar and magmatic liquid: An experimental study. Eos, 53: 553.

Drake, M. and Weill, D., 1975. Partition of Sr, Ba, Ca, Y, Eu2+, Eu3+ and other REE between plagioclase feldspar and magmatic liquid: an experimental study. Geochim. Cosmochim. Acta, 39: 689-712.

Eggins, S.M., 1993. Origin and differentiation of picritic arc magmaa Ambae (Aoba), Vanuatu. Contrib. Mineral. Petrol., 114: 79-100.

Fadili, S.E. and Demaiffe, D., 1999. Petrology of eclogite andf granulite nodules from the Mbuji Mayi kimberlites (Kasai, Congo): Significance of kyanite-omphacite intergrowth. Proceedings of the 7th kimberlite conference: 205-213.

Falloon, T. and Green, D., 1988. Anhydrous partial melting of peridotite from 8 to $35 \mathrm{~kb}$ and the petrogenesis of MORB. J. Petrol., Special Lithospheric Issue: 379-414.

Falloon, T., Green, D., Hatton, C. and Harris, K., 1988. Anhydrous partial melting of a fertile and depleted peridotite from 2 to $30 \mathrm{~kb}$ and application to basalt petrogenesis. J. Petrol., 29: 1257-1282.

Foley, S.F, 1992. Vein-plus-wall-rock melting mechanisms in the lithosphere and the origin of potassic alkaline magmas. Lithos, 28.

Foley, S.F., Barth, M.G. and Jenner, G.A., 2000. Rutile/melt partition coefficients for trace elements and an assessment of the influence of rutile on the trace element characteristics of subduction zone magmas. Geochimica et Cosmochimica Acta, 64: 933-938.

Foley, S.F., Musselwhite, D.S. and VanDerLaan, S.R., 1999. Melt compositions from ultramafic vein assemblages in the lithospheric mantle: a comparison of cratonic and non cratonic settings. Proceedings of the 7 th Int. Kimberlite Conference.

Frey, F.A., 1980. The origin of pyroxenites and garnet pyroxenites from Salt Lake Crater, Oahu, Hawaii: trace element evidence. American Journal of Science, 280 A: 427-449.

Frey, F.A. and Green, D.H., 1974. The mineralogy, geochemistry and origin of lherzolite inclusions in Victorian basanites. Geochim. Cosmochim. Acta, 38: 1023-1059.

Fujimaki, H., Tatsumoto, M. and Aoki, K., 1984. Partition coefficients of Hf, Zr and REE between phenocrysts and groundmasses. Proc. 14th Lunar Planet. Sci. Conf., J. Geophys. Res., 89(Supplement): B662-B672.

Furumoto, A., Webb, J., Odegard, M. and Hussong, D., 1976. Seismic studies on the Ontong Java Plateau. Tectonophysics, 34: 71-90.

Gaetani G. A. and Grove T.L., 1995. Partitioning of rare elements between clinopyroxene and silicate melt: Crystalchemical controls. Geochim. Cosmochim. Acta 59, 1951-1962

Harlow, G.E., 1997. Potassium in clinopyroxene at high pressure and temperature: An experimental study. American Mineralogist, 82: 259-269.

Harte, B. and Kirkley, M.B., 1997. Partitioning of trace elements between clinopyroxene and garnet: data from mantle eclogites. Chem. Geology, 136: 1-24.

Horn, I., Hinton, R., Jackson, S. and Longerich, H., 1997. Ultra-trace elements analysis of NIST SRM 616 using laser ablation microprobe-inductively coupled plasma-mass spectrometry (Lam-ICP-MS: A comparison with secondary ion mass spectrometry (SIMS). Geostand.Newsl., 21: 191-203.

Jacob, D.E., B., S. and Schulze, D.J., 2002. Trace element geochemistry of coesite bearing eclogites from the Roberts Victor kimberlite, Kaapvaal craton. submitted to Lithos.

Jacob, D.E. and Foley, S.F., 1999. Evidence for Archean ocean crust with low high field strength element signature from diamondiferous eclogite xenoliths. Lithos, 48: 317-336.

James, D. E., Fouch M. J., VanDekar J. C., Lee S. v. d., and group K. S. (2001) Tectonic structure beneath southern Africa. Geophys. Res. Lett. 28 (13), 2485-2488.

Katayama, I., C. Parkinson, et al., 2000. "Supersilicic clinopyroxene and silica exsolution in UHPM eclogite and pelitic gneiss from the Kokchetav massif, Kazakhstan." American Mineralogist 85: 1368-1374.

Litasov, K.,.Foley S.F and Litasov, Y., 2000. Magmatic modification and metasomatism of the subcontinental mantle beneath the Vitim volcanic field (East Siberia): evidence from trace element data on pyroxenite and peridotite xenoliths from Miocene picrobasalt. Lithos, 54: 83-114. 
Longerich H. P., Jackson S. E., and Günther D. (1996) Laser ablation inductively coupled plasma mass spectrometric transient signal data acquisition and analyte concentration calculation. J. Anal. Atom. Spectr. 11, 899-904.

Lu, R. and Keppler H. (1997). "Water solubility in pyrope to 100 kbar." Contributions to Mineralogy and Petrology 129: 3542.

Mao, H.K., 1971. The system jadeite $\left(\mathrm{NaAlSi}_{2} \mathrm{O}_{6}\right)$-anorthite $\left(\mathrm{CaAl}_{2} \mathrm{Si}_{2} \mathrm{O}_{8}\right)$ at high pressure. Carnegie Institute Year book, 69 , 163-168 pp.

Milholland C. S. and Presnall D. C. (1998) Liquidus phase relations in the CaO-MgO-Al2O3-SiO2 system at 3.0 GPa: the aluminous pyroxene thermal divide and high-pressure fractionation of picritic and komatiitic magmas. J. Petrol. 39, 3-27.

Moen, H., 1999. The Kheis Tectonic Sub province, southern Africa: A lithostratigraphic perspective. S.Afr.J.Geol., 102: 2742.

Niu, Y. and Batiza, R., 1997. Trace element evidence from seamounts for recycled oceanic crust in the Eastern Pacific mantle. Earth Planet Sci. Lett., 148: 471-483.

Onuma, N., Higuchi, H., Wakita, H. and Nagaswa, H., 1968. Trace element partition between two pyroxenes and the host lava. Earth Planet. Sci. Lett., 5: 47-51.

Paster, H., Schauwecker, D. and Haskin, L., 1974. The behavior of some trace elements during solidification of the Skaergaard layered series. Geochim. Cosmochim. Acta, 38: 1549-1577.

Pollack, H. and Chapman, D., 1977. On the regional variation of heat flow, geotherms, and lithospheric thickness. Tectonophysics, 38: 279-296.

Richards, M., Jones, D., Duncan, R. and Courtillot, V., 1991. A mantle plume initiation model for the Wrangellia flood basalt and other oceanic plateaus. Science, 254: 263-267.

Sato, K., Katsura, T. and Ito, E., 1997. Phase relations of natural phlogopite with and without enstatite up to 8 GPa: implication for mantle metasomatism. Earth and Planetary Science Lett., 146: 511-526.

Saunders, A., Tarney, J., Kerr, A. and Kent, R., 1996. The formation and fate of large oceanic igneous provinces. Lithos, 37: 81-89.

Shaw, C., 1997. The petrology of the layered gabbro intrusion, eastern gabbro, Coldwell alkaline complex, Northwestern Ontario, Canada: evidence for multiple phases of intrusions in a ring dyke. Lithos, 40: 243-259.

Shee, S.R., Bristow, J.W., Bell, D.R., Smith, C.B., Allsopp, H.L. and Shee, P.B., 1986. The petrology of kimberlites, related rocks and associated mantle xenoliths from the Kuruman province, South Africa. Proceedings of the Fourth International Kimberlite Conference, Perth 1986: 60-82.

Smyth, J., 1980. Cation vacancies and the crystal chemistry of breakdown reactions in kimberlitic omphacites. American Mineralogist, 65: 1185-1191.

Snyder, G.A., Taylor, L.A., Crozaz, G., Halliday, A.N., Beard, B.L., Sobolev, V.N. and Sobolev, N.V., 1997. The origins of Yakutian eclogite xenoliths. J. Petrology, 38: 85-113.

Sobolev and Shatsky, V.S., 1990. Diamond inclusions in garnets from metamorphic rocks. Nature, 343: $742-746$.

Storey, M., Mahoney, J., Kroenke, L. and Saunders, A., 1991. Are oceanic plateaus sites of komatiite formation? Geology, 19: 376-379.

Sudo, A. and Tatsumi Y., 1990. Phlogopite and K-amphibole in the upper mantle: implication for magma genesis in subduction zones. Geophysical res. lett. 17, 29-32.

Takahashi, E., 1986. Melting of a dry peridotite KLB-1 up to $14 \mathrm{GPa}$ : Implication on the origin of peridotite upper mantle. Journal of Geophysical Research, 91(B9): 9367-9382.

Tronnes, R. (2000) Stability range and decomposition of potassic richterite and phlogopite end members at 5-15 GPa. Mineralogy and Petrology 74, 129-148.

Walter M. (1998) Melting of garnet peridotite and the origin of komatiite and depleted lithosphere. J. Petrol. 39, 29-60.

Westrenen, W., van, Blundy, J. and Wood, B., 1999. Crystal-chemical controls on trace element partitioning between garnet and anhydrous silicate melt. American Mineralogist, 84: 838-847.

Westrenen, W., van, Blundy, J. and Wood, B., 2001. A predictive thermodynamic model of garnet-melt trace element partitioning. Contrib. MIneral. Petrol. 142, 219-234.

Wood, B. J. and Blundy, J. D., 1997 A pridictive model for rare earth element partitioning between clinopyroxene and anhydrous silicate melt. Conrib.Mineral. Petrol. 129, 166-181.

Zack, T., 2000. Trace element mineral analysis in high pressure metamorphic rocks from Trescolmen, Central Alps. Contribution of Min. Pet.(Göttingen, Univ.,Diss).

Zack, T., Foley, S.F. and Rivers, T., 1998. Trace element partitioning between hydrous minerals (phengite, zoisite, amphibole) and omphacite in eclogites: clues for modelling dehydration reactions in subduction zones. Proc. of the 8th Goldschmidt Conference 1998. 


\section{Acknowledgments}

Ich möchte mich vor allem bei meinen Betreuern Prof. Stephen Foley und Dr. Dorrit Jacob dafür bedanken, daß Sie mich fachlich, moralisch und logistisch immer voll unterstützt haben und mir zudem noch jegliche Freiheiten einräumten, also dafür, daß ich es einfach nicht besser hätte treffen können.

Der DFG danke ich für die finanzielle Unterstützung des Projektes.

Dr. Andreas Kronz danke ich für seine unermüdliche Unterstützung in Sachen Mineralchemie und für die phantastische Leitung des Mikrosondenlabors, die nichts unmöglich läßt. Gedankt sei ebenso Silke Tribold. Weiteren Mitgliedern des Geochemisches Institutes der Universität Göttingen: Dr. Catherine Ginibre, Dr. Tatjana Churikova, Prof. J. Hoefs, und Prof. G. Wörner gilt mein Dank gleichermaßen für logistische Unterstützung, sowie für fruchtbare wissenschaftliche Diskussionen und Ratschläge.

Den ehemaligen Foley's Pub Besuchern: Dr. Thomas Zack, Dr. Frank Schaefer, Dr. Pierre Cartigny, Dr. Richard Brumm und Stefan Buhre danke ich für zahlreiche Diskussionen und viel Spass. Mein besonderer Dank gilt allerdings Dr. Enno Zinngrebe, nicht nur für wertvolle Vorarbeiten zum Zero Projekt sondern auch für ad hoc Korrekturen, nächtliche Ennogramme und Nachhilfestunden in Thermodynamik.

Bei den Mitgliedern des Mineralogischen Institutes der Universität Göttingen: Dr. Cliff Shaw, Prof. Storre, Prof. Nitsch, Frau Köhler und Hr. Brower bedanke ich mich für wissenschaftliche und/oder technische Unterstützung. Mein besonderer Dank gilt Prof. Sharon Webb für wichtige Ratschläge und Notdienste.

Bei Prof. G. Jenner und Mike Tubrett von der Memorial University, St. John's möchte ich mich für die Betreuung im Laser ICP MS Labor bedanken und ganz besonders für die freie Hand, und den Laborschlüssel, der es mir ermöglichte nächtelang zu lasern.

Bei Dr. Michael Wiedenbeck (PhD) vom Geo-Forschungs-Zentrum Potsdam bedanke ich mich für die Betreuung im Ionensonden Labor. Dr. Reiner Thomas danke ich für die Raman-Sonden-Analysen.

Bei Dr. Dave Mattey und vor allem bei Dr. Dave Lowry und Dr. Natalie Grassineaux vom Royal Holloway, University of London, bedanke ich mich für die Betreuung im Labor für Stabile Isotope und nicht allein dafür, daß Sie mit enormem Schlafmangel die Laserfluorinations Messungen ermöglicht haben, sondern auch für interessante Diskussionen und den amüsanten Laborauffenthalt.

Den "Greifswalder Soft- und Hardrockern" sei herzlich gedankt dafür, daß Sie mir so vorurteilsfrei begegnet sind und mich komplett unterstützt haben. Für die gesamte Palette von wissenschaftlichen bis persönlichen Hilfestellungen gilt mein besonderer Dank: Dejan Prelevic, Dr. Karsten Obst, Sebastian Tappe, and especially Jana Berger + Horst (ihr wisst schon).

Für wertvolle wissenschaftliche Diskussionen bedanke ich mich weiterhin bei Prof. P. O’Brien, Prof. Dave Green und Prof. Alex Navrotsky. 


\section{Lebenslauf}

Am 29.12.1966 wurde ich als Tochter von Ida-Maria Schmickler, geborene Penner, und Josef Schmickler in Leverkusen geboren. Von 1973 bis 1977 absolvierte ich in Hannover die Grundschule. Im Anschluß besuchte ich von 1977 bis 1985 das Gymnasium Sophienschule in Hannover, und wechselte 1986 an die Integrierte Gesamtschule Langenhagen, an der ich im Mai 1988 die allgemeine Hochschulreife erlangte. Im Jahre 1988 immatrikulierte ich mich an der Georg-August-Universität in Göttingen und schloss mein Studium 1995 mit dem Diplom in Geologie/Paläontologie ab. Anschliessend arbeitete ich drei Jahre als Geologin in gutachterlicher Tätigkeit. Im Januar 1999 kehrte ich an die Universität zurück und beschäftigte mich am Mineralogisch-Petrologischen Institut der Universität Göttingen, und ab 2001 an der Ernst-Moritz-Arndt Universität Greifswald, mit der Genese von Eklogitxenolithen aus Kimberliten unter der Betreuung von Prof. Stephen Foley. Seit Februar 2002 bin ich am Bayerischen Geoinstitut Bayreuth beschäftigt 